\title{
Permissible Radionuclide Loading for Organic Ion Exchange Resins from Nuclear Power Plants
}

NUREG/CR- -2830

DE84 002898

Manuscript Completed: June 1982

Date Published: October 1983

Prepared by

D. R. MacKenzie, M. Lin, R. E. Barletta

Author

Brookhaven National Laboratory

Upton, NY 11973

\section{Prepared for}

Division of Waste Management

Office of Nuclear Material Safety and Safeguards

U.S. Nuclear Regulatory Commission

Washington, D.C. 20555

NRC FIN A3159

\section{DISCLAIMER}

This report was prepared as an account of work sponsored by an agency of the United States Government. Neither the United States Government nor any agency thereof, nor any of their employees, makes any warranty, express or implied, or assumes any legal liability or responsibility for the accuracy, completeness, or usefulness of any information, apparatus, product, or process disclosed, or represents that its use would not infringe privately owned rights. Reference herein to any specific commercial product, process, or service by trade name, trademark, manufacturer, or otherwise does not necessarily constitute or imply its endorsement, recommendation, or favoring by the United States Government or any agency thereof. The views and opinions of authors expressed herein do not necessarily state or reflect those of the United States Government or any agency thereof.

\section{NOTHEE \\ POBTIOHS OF THIS REPOAT ARE ILLEGIBLE. It has been reproduced irom the best available copy to parmit the hroadest




\section{DISCLAIMER}

This report was prepared as an account of work sponsored by an agency of the United States Government. Neither the United States Government nor any agency Thereof, nor any of their employees, makes any warranty, express or implied, or assumes any legal liability or responsibility for the accuracy, completeness, or usefulness of any information, apparatus, product, or process disclosed, or represents that its use would not infringe privately owned rights. Reference herein to any specific commercial product, process, or service by trade name, trademark, manufacturer, or otherwise does not necessarily constitute or imply its endorsement, recommendation, or favoring by the United States Government or any agency thereof. The views and opinions of authors expressed herein do not necessarily state or reflect those of the United States Government or any agency thereof. 


\section{DISCLAIMER}

Portions of this document may be illegible in electronic image products. Images are produced from the best available original document. 


\section{NOTICE}

This report was prepared as an account of work sponsored by an agency of the United States Government. Neither the United States Government nor any agency thereof, or any of their employees; makes any warranty, expressed or implied, or assumes any legal liability of responsibility for any third party's use, or the results of such use, of any information, apparatus, product or process disclosed in this report, or represents that its use by such third party would not infringe privately owned rights.

\section{Availability of Reference Materials Cited in NRC Publications}

Most documents cited in NRC publications will be available from one of the following sources:

1. The NRC Public Document Room, 1717 H Street, N.W. Washington; DC 20555

2. The NRC/GPO Sales Program, U.S. Nuclear Regulatory Commission, Washington; DC 20555

3. The National Technical Information Service, Springfieid, .VA 22161

Although the listing that follows represents the majority of documents cited in NRC publications, it is not intended to be exhaustive.

Referenced documents available for inspection and copying for a fee from the NRC'Public Document Room include NRC correspondence and ir,ternal NRC memoranda; NRC Office of Inspection and Enforcement bulletins, circulars, information notices, inspection and investigation notices; Licensee Event Reports; vendor reports and correspondence; Commission papers; and applicant and licensee documents and correspondence.

The following documents in the NUREG series are available for purchase from the NRC/GPO Sales Program: formal NRC staff and contractor reports, NRC-sponsored conference proceedings, and NRC booklets and brochures. Also available are Regulatory Guides, NRC regulations in the Code of Federal Regulations; and Nuclear Regulatory Commission /ssuances.

Documents available from the National Technical Information Service include NUREG series reports and tectinical reports prepared by other federal agencies and reports prepared by the Atomic Energy Commission; forerunner agency to the Nuclear Regulatory Commission.

Documents available from public and special technical libraries include all open literature items, such as books, journal and periodical articles; and transactions. Federal Register notices, federal and state legislation, and congressional reports can usually be obtained from these libraries.

Documents such as theses, dissertations, foreign reports and translations, and non-NRC conference proceedings are available for purchase from the organization sponsoring the publication cited.

Single copies of NRC draft reports are available free upon written request to the Division of Technical Information and Document Control, U.S. Nuclear Regulatory Commission, Washington, DC 20555:

Copies of industry codes and standards used in a substantive manner in the NRC regulatory process are maintained at the NRC Library, 7920 Norfolk Avenue, Bethesda, Maryland, and are available there for reference use by the public. Codes and standards are usually copyrighted and may be purchased from the originating organization or, if they are American National Standards, from the American National Standards Instizute, 1430 Broadway. New York, NY 10018.

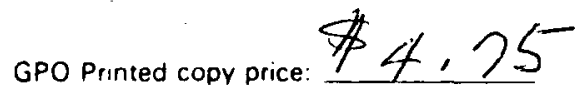


ABSTRACT

A questionnaire on the use of ion exchange resins in nuclear power plants was sent to all operating reactors in the U.S. Responses were received from 23 of the 48 utilities approached. Information was sought concerning the amounts of radionuclides held by the resins, and the effects of its radiation on the resins both during operation and after removal from service. Relevant information from the questionnaires is summarized and discussed. Available literature on the effects of ionizing radiation on organic ion exchange resins has been - reviewed. On the basis of published data on damage to resins by radiation, the technical rationale is given to support NRC's draft branch technical position on a maximum permissible radionuclide loading. It is considered advisable to formulate the rule in terms of a delivered dose rather than a curie loading. A maximum permissible dose of 108 rad is chosen because, while it is large enough that a measurable amount of damage will be done to the resin, it is small enough that the damage will be negligible at a power plant or disposal site. A test procedure has been written which a generator could use to qualify a specific resin for service at a higher dose than permitted by the general rule. 
CONTENTS

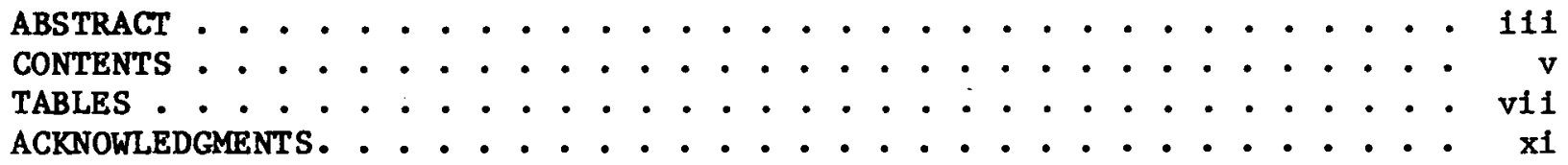

1. INTRODUCTION. • • • • • • • • • • • • • . . • . . . . . . . . . 1

2. RESPONSE TO SURVEY QUESTIONNAIRE. • • • • • • • • • • • • • • . . . . 3

2.1 Resin Use and Operating Conditions . . . . . . . . . . . . . . 3

2.1 .1 Kinds of Resin. . . . . . . . . . . . . . . . . . 3

2.1.2 Type of Operation .................... . 3

2.1 .3 Temperature . . . . . . . . . . . . . . . . . . 4

2.1 .4 Criteria for Resin Replacement. . . . . . . . . . . . . 4

2.1.5 Relative Radiation Exposure and Evidence of

Radiation Damage. . . . . . . . . . . . . . . 4

2.2 Activity Levels and Principal RNs in Liquid Streams. . . . . 5

2.3 Activity Loading and Principal RNs on Resins for Disposa1. . . 10

2.4 Sr-90 in Power Plant Wastes. . . . . . . . . . . . . . . . . 16

2.5 TRU Isotopes on Spent Resins . . . . . . . . . . . . . . . . . 17

2.6 Disposal Information . . . . . . . . . . . . . . . . . . . 18

2.6 .1 Methods . . . . . . . . . . . . . . . . . . . 18

2.6.2 Amounts . . . . . . . . . . . . . . . . . . . . 18

3. SELECTION OF A MAXIMUM PERMISSIBLE LOADING. • • • • • • • • • • • 19

3.1 Need for a Loading Limit . . . . . . . . . . . . . . . . . . . 19

3.2 Literature Information on Radiation Damage . . . . . . . . . 19

3.2.1 General Princtples. . . . . . . . . . . . . . . . 20

3.2.2 Effect on Exchange Capacity . . . . . . . . . . . . . . 21

3.2.3 Gas Generation. . . . . . . . . . . . . . . . 23

3.2.4 Work Related to TMI-II Cleanup. . . . . . . . . . . . . 26

3.2.5 Nuclear Grade Resins. . . . . . . . . . . . . . . . . . 31

3.3 Cholce of a Maximum Loading Limit. . . . . . . . . . . . . . 32

3.3.1 Basic Considerations. . . . . . . . . . . . . . . . . 32

3.3.2 Minimum Deleterious Changeg in Properties . . . . . . 32

3.3.3 Dose Rate Effects . . . . . . . . . . . . . . . 35

3.3.4 Selection of the Maximum Dose - . . . . . . . . . . . . 36

3.4 Regulatory Use of Delivered Dose . . . . . . . . . . . . . . . 37

3.4.1 Technical Bas1s . . . . . . . . . . . . . . . . 37

3.4.2 Calculation of Total Dose . . . . . . . . . . . . . 37

3.4.3 Sr-90 Reporting Requirements. . . . . . . . . . . . . 38

3.5 Recommendations for Additional Research. . . . . . . . . . . 38

3.6 Dose From Short-Lived RNs During Operation . . . . . . . . . . 39

3.6.1 Potential for Damage... . . . . . . . . . . . . . 39

3.6.2 Dose Determinations and Relevance to a Maximum

Loading Rule. . . . . . . . . . . . . . . . 39 
CONTENTS, Continued

3.7 Solidified Resins. . . . . . . . . . . . . . . . . 41

3.7.1 Experimental Results of Radiation Damage Studies. . . . 41

3.7.2 Conclusions Regarding Maximum Loading . . . . . . . . 42

3.7.3 Recommendations for Additional Research . . . . . . 42

4. TEST FOR PERMITTING EXCEPTIONS TO THE GENERIC RULE. . . . . . . . . 45

4.1 Adequate Simulation of Conditions Expected in Practice . . . 45

4.1 .1 Use of Chemical Solutions . . . . . . . . . . . . 45

4.1 .2 Use of Radiation. . . . . . . . . . . . . . . . 46

4.2 Choice of Irradiation Method . . . . . . . . . . . . 46

4.2.1 Internal Irradiation. . . . . . . . . . . . . . 46

4.2.2 External Irradiation. . . . . . . . . . . . . . 47

4.3 Suitable Properties on Which to Base a Test. . . . . . . . 47

4.3.1 Changes in Appearance . . . . . . . . . . . . . . 47

4.3.2 pH Change and Enhancement of Corrosion. . . . . . . 48

4.3.3 Exchange Capacity . . . . . . . . . . . . . 48

4.3.4 Gas Generation. ................... 49

4.3.5 Final Choice of Measurement to be Used. . . . . . . 49

4.4 Development of the Test................. 49

4.4.1 Specific Requirements . . . . . . ....... 50

4.4.2 Limit for Acceptable Amount of Gas Generation

During Test . . . . . . . . . . . . . . 50

4.4.3 Standard Test Procedure ............ 51

5. SUMMARY AND CONCLUSIONS . . . . . . . . . . . . . . . 55

5.1 Power Plant Survey ... . . . . . . . . . . . . 55

5.2 Published Information on Radiation Damage to Resins. . . . . 57

5.3 Maximum Permissible Dose ... . . . . . . . . . . . 58

5.4 Development of Test for Exception to the Maximum Dose Rule . . 59

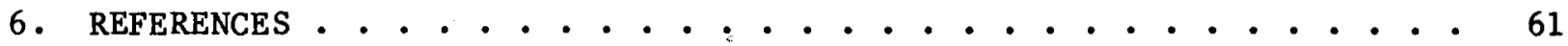

APPENDIX A - 1. BLANK COPY OF QUESTIONNAIRE ON ION EXCHANGE RESIN USAGE IN NUCLEAR POWER PLANTS

2. SUMMARY OF RESPONSES OF INTEREST TO THIS REPORT . . . . 63

APPENDIX B - ANALYTICAL DATA SHEETS FOR RADIONUCLIDE CONCENTRATIONS IN REACTOR COOLANT . . . . . . . . . . . . . . 75

APPENDIX C - ANALYTICAL DATA SHEETS FOR RADIONUCLIDE LOADINGS ON SPENT RESIN FROM REACTOR COOLANT CLEANUP. . . . . . . . . . . 81 


$$
\text { CONTENTS, Continued }
$$

APPENDIX D - ANALYTICAL DATA SHEET FOR LOADING OF TRANSURANIC NUCLIDE ON SPENT REACTOR COOLANT CLEANUP RESIN . . . . . . . . . . 91

APPENDIX E - COMPUTER PROGRAM FOR CALCULATING DOSE DELIVERED TO ORGANIC ION EXCHANGE RESIN BEDS BY DIFFERENT RADIONUCLIDE LOADINGS. 93

APPENDIX F - DETERMINATION OF DOSE DELIVERED BY SHORT-LIVED RADIONUCLIDES TO REACTOR COOLANT CLEANUP RESIN AT DRESDEN NUCLEAR POWER STATION, UNIT 3..................... 95 
2.1 Radiation Fields at the Surface of Resin Bed Vessels . . . . . 5

2.2 Concentration of RNs in Feeds to Different Demineralizer

Resin Beds......................... . 7

2.3 Principal Radionuclides in Primary Coolant . . . . . . . . 7

2.4 Concentrations of Radionuclides in Reactor Coolant at Dresden

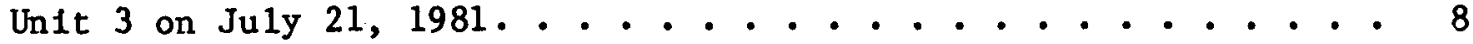

2.5 Concentrations of Radionuclides in Reactor Coolant at St Lucle . . 8

2.6 Concentrations of Radionuclides in Reactor Coolant at

Donald C. Cook Untt 1. . . . . . . . . . . . . . . 9

2.7 Concentrations of Radionuclides in Reactor Coolant at

Fort Calhoun on August 17, 1981. . . . . . . . . . . . . . 9

2.8 Concentrations of Radionuclides in Reactor Coolant at

Point Beach Unit 1 on January 20, 1981 . . . . . . . . . . 10

2.9 Typica 1 and Maximum "High Level" Resin Loadings. . . . . . . . 11

2.10 Princlpal Radionuclides on Resins. . . . . . . . . . . . 12

2.11 Levels of Radionuclides on Resin for Shipment at Donald C. Cook on June 21,1981 . . . . . . . . . . . . . . . . . 12

2.12 Levels of Radionuclides on Unit 1 Coolant Cleanup Resin at

E. I. Hatch. . . . . . . . . . . . . . . . 13

2.13 Levels of Radionuclides on Resin for Shipment at Malne Yankee on March 11, 1980 . . . . . . . . . . . . . . . . . 13

2.14 Levels of Radionuclides on Resin for Shipment at Peach Bottom. . . 14

2.15 Levels of Radionuclides on Resin From Trojan on May 14, 1981 . • 14

2.16 Levels of Radionuclides on Reactor Cleanup Resin at

Vermont Yankee ................... 15

2.17 Alpha Nuclide Levels on a Filter and a Resin Samples at Trofan . . 17

3.1 G-Value for Loss of Sulfonic Acid Groups as a Function of Dose for Dowex 50 of Varlous Cross-Linkages . . . . . . . . . 
TABLES, Continued

3.2 G-Values for Gaseous Product Formation During the Radiation

Decomposition of Ion Exchange Resins . . . . . . . . . . . . 24

3.3 Yields of Product Gases From $7.9 \times 10^{8}$ rad Irradiation of

Dewatered Cation and Anion Exchange Resin. . . . . . . . . . .

$3.4 \mathrm{pH}$ of Water in Contact With Irradiated Cation Exchange

Resin IRN-77........................... 30

A.1 Summary of Pertinent Results From Survey of Organic Ion Exchange

Resin Usage by LWRs. . . . . . . . . . . . . . . . . 69

A.2 Summary of Pertinent Results From Survey of Organic Ion Exchange

Resin Usage by LWRs. . . . . . . . . . . . . . . . 71

A.3 Summary of Pertinent Results From Survey of Organic Ion Exchange

Resin Usage by LWRs. . . . . . . . . . . . . . . . . . . 73

B.1 Data Sheet From Dresden Un1t 3. . . . . . . . . . . . 76

B.2 Data Supplied by St. Lucie. Copy of Addendum II . . . . . . . . . 77

B.3 Data Sheet From Donald C. Cook Unit 1. . . . . . . . . . . 78

B.4 Data Sheet From Fort Calhoun . . . . . . . . . . . . . . 79

B.5 Data Sheet From Point Beach Unft 1 . . . . . . . . . . . 80

C.1 Data Sheet From Donald C. Cook Unit 1. . . . . . . . . . . . 82

C.2 Loading Calculation From Donald C. Cook Unit 1 . . . . . . . . 83

C.3 Data Sheet From E. I. Hatch Unit 1. . . . . . . . . . 84

C.4 Data Sheet From Ma1ne Yankee . . . . . . . . . . . . . . . 85

C.5 Data Sheet From Peach Bottom . . . . . . . . . . . . . 86

C.6 Data Sheet for Resin Shipments, Peach Bottom . . . . . . . . 87

C.7 Data Sheet From Trojan . . . . . . . . . . . . . . . 88

C.8 Data Sheet From Vermont Yankee . . . . . . . . . . . . 89

D.1 Data Sheet From Trojan . . . . . . . . . . . . . . . 91

$$
1 x / x
$$




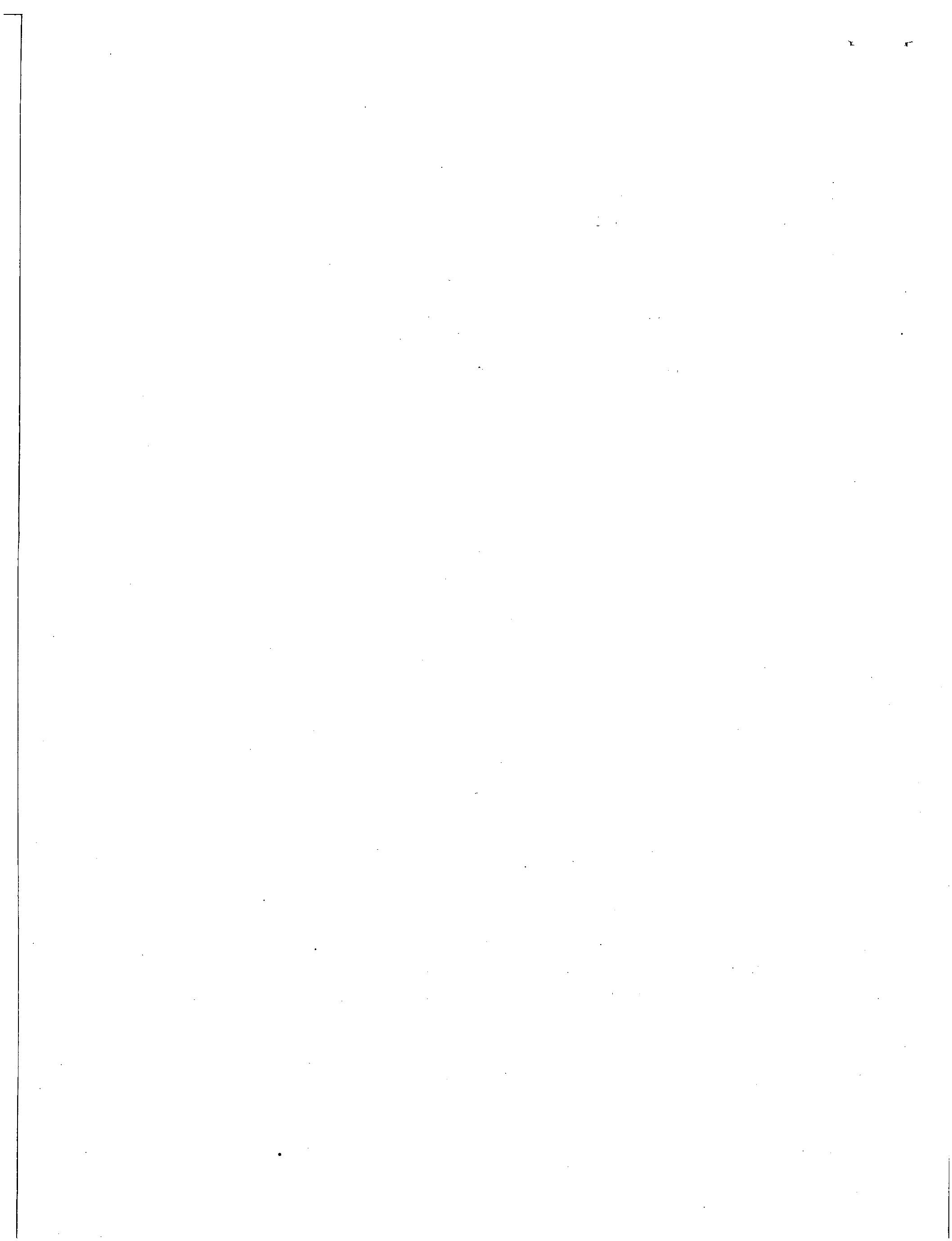

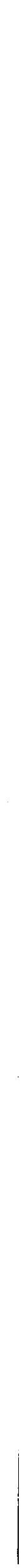


The authors express their appreclation to the utility personnel who replied to the resin usage questionnaire. We are grateful to $\mathrm{Dr}$. Richard E. Davis for helpful suggestions during review of the manuscript. Helpful discussions with Drs. Karl J. Swyler and Paul L. Piclulo a re also acknowledged. Sincere apprectation is extended to Ms. Nancy Yerry and Ms. Kathy Becker for their skillful preparation of the manuscript. 
PERMISSIBLE RADIONUCLIDE LOADING FOR

ORGANIC ION EXCHANGE RESINS FROM NUCLEAR POWER PLANTS

\section{INTRODUCTION}

Organic ion exchange resins are used in nuclear power plants to control the purity of such liquid streams as the primary coolant, turbine condensate, water in the spent fuel storage pools, and the liquid radwaste resulting from all phases of plant operation. In the process, the resins pick up radioactive ionic species and particulate matter. The amount of radioactivity can be relatively large, particularly for resins used to treat the primary coolant.

All organic molecules, including those constituting lon exchange resins, undergo decomposition when exposed to ionizing radiation. Therefore, the resins used in power plants could be significantly degraded if they picked up sufficient activity before being removed from service, since degradation can occur long after removal from service.

In order to obtain information regarding the magnitude of such radiation damage received in actual power plant practice, a questionnaire on resin usage was sent to all the operating light water power reactors in the U.S.

This questionnaire differed from those used in previous surveys $(1,2)$ in focusing more on disposal methods and practices than on operating conditions and procedures. For purposes of the present report, information was sought particularly on the levels of radioactivity to which the resins are exposed during operation, and the curle loadings on the spent resins which are shipped for disposal. The results of the survey responses are reviewed in the next section of the report.

Information on the effects of lonizing radiation on ion exchange materials published up to about 1964 is given in a book by Egorov and Novikov.(3) The book covers most of the work done in Russia and Eastern Europe, but there are gaps in the coverage of papers published in the West. These gaps were filled and the subject brought up to date to approximately the end of 1977 , in a comprehensive review by Gangwer, Goldstein and P11lay. (4) More recent data of particular interest in the evaluation of ef fects of high radiation doses to resins used for nuclear waste disposal have been obtalned from work done in connection with the TMI-II auxillary building (AFHB) cleamup activities. Several studies were done on resins similar to those employed at TMI, using high integral doses. (5-7) Results of these studies were reviewed in a recent BNL report $(8)$ and will be discussed in section 3.2 .4 .

There is wide varlation in resistance to radiation of the many organic cation and anton exchange resins avallable commercially. However, there appears to be sufficient simflarity in behavior among the relatively few different nuclear grade resins of each class (cation and anion) presently used in nuclear power plants that a reasonable assessment can be made of a maximum 
acceptable radiation dose for these resins as a class. On the basis of the data that have been published, NRC has recommended in a draft branch technical position(9) that resins should not be loaded to bulk specific activities greater than $10 \mathrm{ci} / \mathrm{ft}^{3}$, which is approximately equivalent to a dose of $10^{8} \mathrm{rad}$ for long-term decay of $\mathrm{Cs}-137$ and $\mathrm{Sr}-90$. In the event that the waste generator wishes to load resins to a higher level than $10 \mathrm{ci} / \mathrm{ft}^{3}$ (and thus subject them to a long-term dose greater than $10^{8}$ rad) NRC would require demonstration that the resin proposed for use will not undergo significant radiation degradation at the higher loading.

The purpose of this report is twofold. First, it presents the technical rationale in support of the maximum loading limft. Second, since the maximum loading criterion is to a certain extent based on generic analysis of radiation effects on organic ion exchange media, an attempt is made to define a test for use on a case-by-case basis to determine whether, for a given resin, a higher total dose than $10^{8}$ rad might be acceptable. The discussion in this report relies mainly upon effects observed for unsolidified resins. Thus, by and large, the impact of solidification upon the maximum loading limit was felt to be outside the scope of this study. There is limited evidence which indicates that cement solidification of organic ion exchange media may mitigate the deleterious effects seen upon irradiation of unsolidified resins. If this indeed should prove to be the case, then a reasonable maximum acceptable loading limit for solidifled resin waste may well be different than for unsolidified resin waste. Since insufficient data exist to make this assessment, however, recommendations for future work in this area have been included. 


\section{RESPONSES TO SURVEY QUESTIONNAIRE}

The questionnaire on usage of ion exchange resins was sent to $48 \mathrm{U} . \mathrm{S}$. ut1lities operating 65 nuclear power plants. Responses were returned by 23 companies, giving data for 34 units, and information was obtained by telephone from two other companies. A copy of the questionnaire is reproduced in Appendix A, along with tables summarizing the answers to questions which were of particular interest for this report. Coples of most of the completed questionnaires which were returned are included in an appendix to a report on high integrity containers* to be published soon.

\subsection{Resin Use and Operating Conditions}

Relevant information on these topics as gathered from the survey responses is summarized below.

\subsubsection{Kinds of Resin}

(a) It appears that inorganic ion exchangers are not used in commercial nuclear power plants on a routine basis. All responses to the survey question on use of inorganic resins were negative.

(b) The most frequently used organic resins were strong acid cation exchangers (with sulfonic acid functional groups), and strong base anion exchangers (with quaternary ammonium functional groups). It appears to be the practice throughout the industry to use nuclear grade resins. A few plants did not report the spectfic resins used, but the remainder indicated use of nuclear grade only. (A description of nuclear grade resins is given in section 3.2.5.) For the beds used to clean primary coolant (those of most interest to this report because of the higher radiation doses they receive), the ma jority of reactors use mixed bed resins, with cation: anion ratios usually $1: 1$, though a number use separate cation and/or anion beds as well as the mixed beds.

\subsubsection{Type of Operation}

Al1 PWRs responding to the questionnalre used deep beds containing bead-type resin. In general, BWRs used powdered resins in the so-called "Powdex" type of operation for reactor coolant cleanup, although two of the nine respondents used deep bed operation.

\footnotetext{
${ }^{*}$. L. Piciulo, "Technical Considerations for High Integrity Containers for the Disposal of Radloactive Ion Exchange Resin Waste," Draft Report, BNL-NUREG-30404, December 1981.
} 


\subsubsection{Temperature}

The various demineralizer systems in the plants operate at reported temperatures of 75 to $150^{\circ} \mathrm{F}$. Operating temperatures for the coolant cleanup beds are generally $100-120^{\circ} \mathrm{F}$, with none reported over $140^{\circ} \mathrm{F}\left(60^{\circ} \mathrm{C}\right)$.

\section{1 .4 Criteria for Resin Replacement}

Almost all the PWR's responding use too great a drop in decontamination factor (DF) as the principal criterion for replacing resin in the coolant cleanup bed. (DF is defined as the ratio of radioactivity in the influent to that in the effluent). The results of Clark's survey(2) are essentially the same: In that survey only one PWR (Maine Yankee) out of thirteen responding used something other than low DF as the main criterion. That exception was the use of "Li breakthrough or high radiation (100-300 $\mathrm{R} / \mathrm{h}$ external to vesse1)." It should be noted that in the present survey Maine Yankee reports using only low DF.

BWR's use mainly undestrably high pressure drop across the bed and undesirably high conductivities of the effluent. None reported using low DF as the main criterion. This is consistent with the results of clark's survey where only one plant (LaCrosse) used low DF as its replacement criterion.

\subsubsection{Relative Radiation Exposures and Evidence of Radiation Damage}

Along with the request for information on criterla for resin replacement, we asked for the gamma-radiation field at the surface of resin bed vessels, and for any evidence of radiation damage to the resins. Values for the radiation fields were reported by several plants and are given in Table 2.1.

It is obvious that at the plants supplying these data, the primary coolant cleanup beds generate a radiation field many times greater than that of the beds in the other demineralizer systems. One would assume that this situation holds for all plants. This is expected since the primary coolant continuously flows through the high neutron flux of the reactor.

None of the plants responding to the survey reported any evidence of radiation damage to the resins. This is not surprising since spent resins are not stored for a long time after being taken out of service. In some plants, spent resins are shipped for disposal without storage, and the longest storage period seems to be about a year. Since the half-lives of the dominant radionuclides (RNs) with which the spent resins are loaded ( $\mathrm{Co}-60$ and $\mathrm{Cs}-137$ ) are 5.3 and 30 years respectively, only a small fraction of the total dose eventually deposited will be recelved before shipment. It is interesting that one plant (Duane Arnold) reported relatively rapid gas pressure buildup in their drums of dewatered resins. This was due to bacterial action rather than radiation damage, since addition of formaldehyde, a biocide, could control the situation. To avold the problem, they now solidify all their spent resins with cement and ship within a short period before any gas which might eventually form can bulld up appreclably. 
Table 2.1

Radiation Fields at the Surface of Resin Bed Vessels

\begin{tabular}{|c|c|c|c|c|}
\hline \multirow[b]{2}{*}{ Plant } & \multicolumn{3}{|c|}{ Field $(R / h)$ at Bed in: } & \multirow[b]{2}{*}{ Fuel Poo1 } \\
\hline & $\begin{array}{l}\text { Primary } \\
\text { Coolant }\end{array}$ & $\begin{array}{l}\text { Condensate } \\
\text { or Boron Recycle }\end{array}$ & Radwaste & \\
\hline BWR's & & · & & \\
\hline$\overline{\text { Dresden }}$ & $50-200$ & $1-3$ & $1-5$ & $10-100$ \\
\hline Peach Bottom & --- & -- & $0.3-0.6$ & $7-12$ \\
\hline \multicolumn{5}{|l|}{ PWR's } \\
\hline$\overline{\text { Beaver Valley }}$ & $\leq 500$ & $-\infty$ & --- & -- \\
\hline Donald C. Cook & 500 & 0.5 & -- & 35 \\
\hline MaIne Yankee & $500-1000$ & -- & --- & -- \\
\hline Yankee Rowe & $5-100$ & --- & -- & $\leq 3$ \\
\hline Zion & 100 & 1 & 5 & 1 \\
\hline
\end{tabular}

\subsection{Activity Levels and Principal RNs in Liquid Streams}

Questions were asked in the survey regarding the gross $\alpha-$ and $\beta, \gamma-$ activities in the liquid streams before and after the various resin beds. It was also requested that the principal RNs in those streams be identified. A number of plants (8) did not respond to these questions, but most (15) gave data on gross $\beta, \gamma$-activity and some sent copies of analytical results giving a breakdown according to individual RN. A summary of the data on gross $\beta, \gamma-$ activity in the different liquid streams is presented in Table 2.2. The principal RNs in the reactor coolant are 1isted in Table 2.3 for those reactors responding to that question. Amounts of the individual RNs are given in order of decreasing activity level in Tables 2.4-2.8 for the plants which sent detailed analysis sheets. The actual sheets are reproduced in Tables $B-1$ to B-4 of Appendix B. It should be noted that one of the analysis records sent (St. Lucie Plant, Unit 1) was a copy of Addendum II to Table 31 of Clark's 1978 report, (2) but the remainder were obtained during recent operations.

Table 2.2 indicates that activity levels in the various liquid streams do not vary widely from plant to plant, or from BWR to PWR. In general, the levels in the reactor coolant are considerably above those in the other streams, as would be expected. From Tables 2.4-2.8, the breakdown into individual RN activity levels shows that, in reactor coolant, the short-lived isotopes (mostly fission products and not necessarily in true solution) contribute essentially all the radioactivity, while the long-lived fission and activation products ( $\mathrm{Cs}-137$ and $\mathrm{Co}-60)$ generally contribute much less than $1 \%$. Clark's survey (2) obtained detailed RN analyses from two BWR's and four PWR's, all 
of them different from our responding plants except for Donald C. Cook and the aforementioned St. Lucie. The information obtained was very similar in extent and significance to that from the present survey.

In the present survey, as in Clark's, the detailed analyses show a considerable variation in the list of isotopes monitored at the different plants. Discussions with representatives of the plants indicate that there is, in fact, a wide variation in the proportions of the various RNs found in the coolant of different reactors. This variation is first of all due to the relative amounts of fission products compared to activation products, which in turn depend on a number of factors such as extent of fue 1 leaks, age of the reactor, and operating power level. Distribution of the more prominent RNs at a given reactor can change with time also, depending on reactor operating conditions, development of fuel leaks, and chemlcal treatment of the coolant. As an example of this last effect, addition to the coolant of hydrogen peroxide (which has been done at a number of plants) causes release of cobalt from the surface of reactor components in contact with the coolant. Thus, after such treatment, very large increases in the levels of Co-58 and Co-60 in the coolant will occur.

In addition to actual differences in RN distribution at different reactors, there is a difference in those RNs reported, because of specific analytical methods used. All plants appear to use $\gamma$-spectroscopy for analysis. Some plants record all RNs definitely identifiable. Others monitor on $1 y$ certain sets of RNs as determined by the computer software provided by the vendor of their analytical equipment. Their computer programs, after reporting amounts of the RNs being monitored; give the energies and count rates of all other $\gamma$-peaks observed. Thus, if any new RN shows up or an unusual increase is noted in any peak, appropriate additions can be made to the analytical procedure to keep track of the situation.

The results reported by Dresden and St. Lucle are the most extensive, and in terms of relative concentrations, are in reasonable agreement for those RNs common to both plants. The apparent discrepancy in the distibution of iodine isotopes (reversal of I-133 and -134 a bundances, and the high I-131 leve 1 at St. Lucle) is probably indicative of release of the longer-lived isotopes (131 and 133) in a reactor trip at St. Lucie shortly before analysis. The other plants report mainly lodine and noble gas isotopes for their principal contributors to the gross $\beta, \gamma$-activity, and amounts of these isotopes are consistent with those reported by Dresden and St. Lucie.

A point to note regarding the relatively short-lived isotopes is that during reactor operation they will rapidly bulld up to steady state saturation levels on the resin beds and will thus constitute constant dose rate radiation sources, assuming constant reactor power. They could therefore deliver a significant radiation dose to the resins if the beds were kept in service for periods of several months. The magnitude of this effect is discussed in detail in a later section (3.5). 
Table 2.2

Concentration of RNB in Feeds

to Different Demineralizer Resin Beds

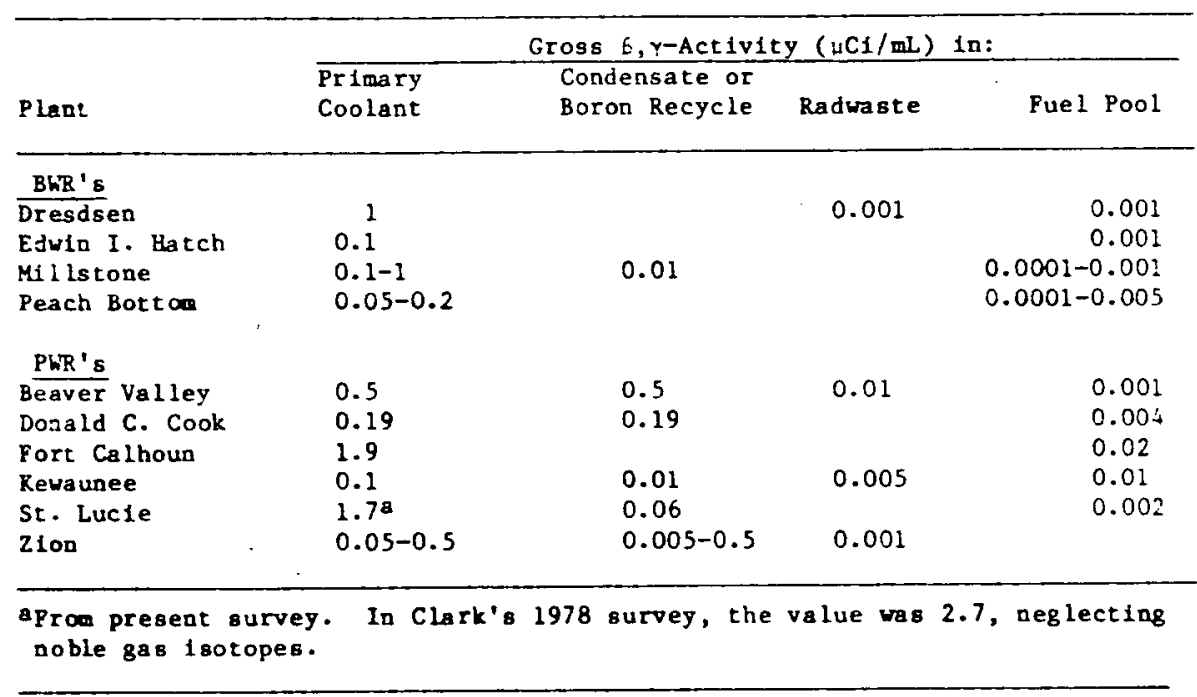

Ta ble 2.3

Princlpal Radionuclides In Primary Coolant

\begin{tabular}{|c|c|}
\hline Plant & Princlpal Radionuclides \\
\hline $\begin{array}{l}\frac{\text { BUR'B }}{\text { Cooper }} \\
\text { Dresden } \\
\text { Duane Arnold } \\
\text { M1llatone }\end{array}$ & 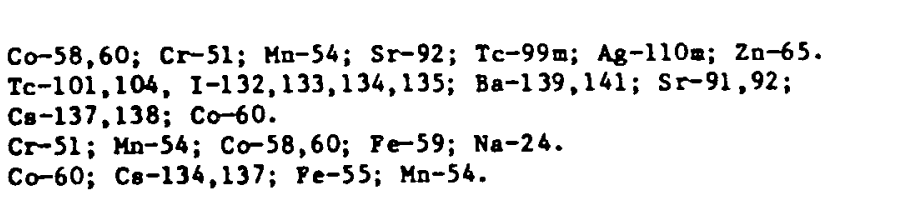 \\
\hline $\begin{array}{l}\text { Pur'e } \\
\text { Port Calhoun } \\
\text { Reraunee } \\
\text { Haine Yankee } \\
\text { Point Beach } \\
\text { St. Lucie } \\
\text { Yankee Rowe. } \\
\text { Zion }\end{array}$ & 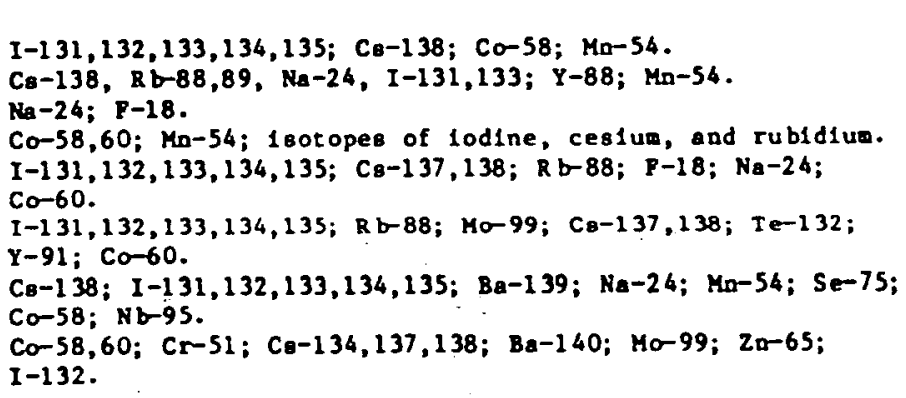 \\
\hline
\end{tabular}


Table 2.4

Concentrations of Radiomaldes in Reactor Coolant at Dresden Unit 3 on July 21, 1981

\begin{tabular}{|c|c|c|c|}
\hline Isotope & $\mu \mathrm{CL} / \mathrm{mL}$ & Isotope & 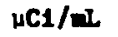 \\
\hline $\begin{array}{l}T c-101 \\
I-134 \\
T c-104 \\
B a-141 \\
B a-139 \\
I-135 \\
I-132 \\
S r-92 \\
C g-138 \\
T c-99 m \\
I-133 \\
S r-91 \\
M o-99 \\
B a, I a-140 \\
N p-239 \\
I-131\end{array}$ & $\begin{array}{ll}4.6 & \mathrm{E}-1 \\
4.4 & \mathrm{E}-1 \\
4.2 & \mathrm{E}-1 \\
1.8 & \mathrm{E}-1 \\
1.7 & \mathrm{E}-1 \\
1.4 & \mathrm{E}-1 \\
1.3 & \mathrm{E}-1 \\
8.6 & \mathrm{E}-2 \\
6.9 & \mathrm{E}-2 \\
6.5 & \mathrm{E}-2 \\
5.7 & \mathrm{E}-2 \\
3.2 & \mathrm{E}-2 \\
9.5 & \mathrm{E}-3 \\
6.3 & \mathrm{E}-3 \\
6.0 & \mathrm{E}-3 \\
5.1 & \mathrm{E}-3\end{array}$ & $\begin{array}{l}\mathrm{Na}-24 \\
\mathrm{Cr}-51 \\
\mathrm{Co}-60 \\
\mathrm{Fe}-59 \\
\mathrm{Mn}-54 \\
\mathrm{Ag}-76 \\
\mathrm{Ce}-141 \\
\mathrm{Ru}-103 \\
\mathrm{Co}-58 \\
\mathrm{Nb}-95 \\
\mathrm{C}-136 \\
\mathrm{Z}-95 \\
\mathrm{Zn}-65 \\
\mathrm{Sb}-124 \\
\mathrm{Cg}-137 \\
\mathrm{Ag}-110 \mathrm{~m}\end{array}$ & $\begin{array}{ll}4.2 & \mathrm{E}-3 \\
2.4 & \mathrm{E}-3 \\
1.3 & \mathrm{E}-3 \\
5.9 & \mathrm{E}-4 \\
4.4 & \mathrm{E}-4 \\
3.4 & \mathrm{E}-4 \\
2.9 & \mathrm{E}-4 \\
2.7 & \mathrm{E}-4 \\
2.6 & \mathrm{E}-4 \\
1.6 & \mathrm{E}-4 \\
1.5 & \mathrm{E}-4 \\
1.5 & \mathrm{E}-4 \\
7.3 & \mathrm{E}-5 \\
6.5 & \mathrm{E}-5 \\
1.8 & \mathrm{E}-5 \\
7.7 & \mathrm{E}-6\end{array}$ \\
\hline
\end{tabular}

Table 2.5

Concentrations of Radionuclides in Reactor Coolant at St. Lucie; Data Complled for Clark's Report(2) It 1978.

\begin{tabular}{|c|c|c|c|}
\hline Isotope & $\mu \mathrm{Cl} / \mathrm{ml}$ & Isotope & $\mu \mathrm{Cl} / \mathrm{mL}$ \\
\hline 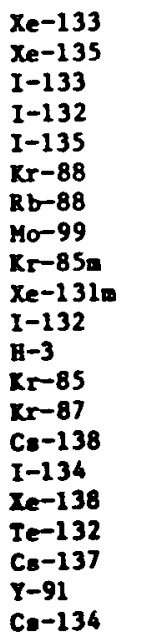 & $\begin{array}{ll}2.49 & \mathrm{E}+1 \\
1.64 & \mathrm{E}+1 \\
7.81 & \mathrm{E}-1 \\
5.48 & \mathrm{E}-1 \\
3.72 & \mathrm{E}-1 \\
3.59 & \mathrm{E}-1 \\
3.52 & \mathrm{E}-1 \\
2.80 & \mathrm{E}-1 \\
2.05 & \mathrm{E}-1 \\
2.04 & \mathrm{E}-1 \\
1.50 & \mathrm{E}-1 \\
1.47 & \mathrm{E}-1 \\
1.27 & \mathrm{E}-1 \\
1.12 & \mathrm{E}-1 \\
9.52 & \mathrm{E}-2 \\
8.56 & \mathrm{E}-2 \\
4.97 & \mathrm{E}-2 \\
4.55 & \mathrm{E}-2 \\
4.42 & \mathrm{E}-2 \\
1.53 & \mathrm{E}-2 \\
1.38 & \mathrm{E}-2\end{array}$ & $\begin{array}{l}R b-89 \\
B r-84 \\
C o-58 \\
C r-51 \\
T e-129 \\
C z-136 \\
T e-134 \\
B a-140 \\
L a-140 \\
P r-143 \\
C o-60 \\
S r-89 \\
C e-140 \\
R u-103 \\
S r-91 \\
Y-90 \\
M n-54 \\
\text { Sr-90 } \\
\text { Ru-106 } \\
\text { Fe-59 } \\
Z r-95\end{array}$ & 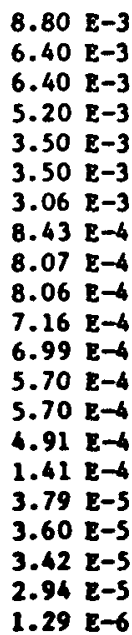 \\
\hline
\end{tabular}


Ta ble 2.6

Concentrations of Radionuclides in Reactor Coolant at Donald C. Cook Unit 1.

\begin{tabular}{|c|c|}
\hline Isotope & $\mu \mathrm{Ci} / \mathrm{mL}$ \\
\hline $\mathrm{Xe}-133$ & $1.56 \mathrm{E}-1$ \\
\hline $\mathrm{Xe}-135$ & $6.49 \mathrm{E}-2$ \\
\hline Cs-138 & $3.60 \mathrm{E}-2$ \\
\hline $\mathrm{Rb}-88$ & $1.53 \mathrm{E}-2$ \\
\hline $\mathrm{Na}-24$ & $8.93 \mathrm{E}-3$ \\
\hline$I-131$ & $8.17 \mathrm{E}-3$ \\
\hline $\mathrm{Kr}-85 \mathrm{~m}$ & $8.01 \mathrm{E}-3$ \\
\hline $\mathrm{Xe}-133 \mathrm{~m}$ & $6.30 \mathrm{E}-3$ \\
\hline $\mathrm{Kr}-88$ & $5.07 \mathrm{E}-3$ \\
\hline$K x-87$ & $4.95 \mathrm{E}-3$ \\
\hline$I-133$ & $3.93 \mathrm{E}-3$ \\
\hline $\mathrm{Y}-88$ & $3.82 \mathrm{E}-3$ \\
\hline $\mathrm{R} b-89$ & $3.35 \mathrm{E}-3$ \\
\hline$M n-54$ & $1.98 \mathrm{E}-3$ \\
\hline Ar-41 & $1.89 \mathrm{E}-3$ \\
\hline
\end{tabular}

Table 2.7

Concentrations of Radionuclides in Reactor Coolant at Fort Calhoun on August 17, 1981

\begin{tabular}{lc}
\hline Isot ope & $\mu \mathrm{CI} / \mathrm{mL}$ \\
\hline $\mathrm{Xe}-133$ & $9.70 \mathrm{E}-1$ \\
$\mathrm{Xe}-135$ & $1.96 \mathrm{E}-1$ \\
$\mathrm{Cs}-138$ & $1.28 \mathrm{E}-1$ \\
$\mathrm{I}-133$ & $8.07 \mathrm{E}-2$ \\
$\mathrm{I}-132$ & $7.52 \mathrm{E}-2$ \\
$\mathrm{I}-134$ & $6.15 \mathrm{E}-2$ \\
$\mathrm{I}-131$ & $5.12 \mathrm{E}-2$ \\
$\mathrm{Co}-58$ & $1.56 \mathrm{E}-2$ \\
$\mathrm{Mn}-54$ & $7.19 \mathrm{E}-3$ \\
$\mathrm{Ce}-141$ & $7.09 \mathrm{E}-3$ \\
$\mathrm{Nb}-95$ & $4.37 \mathrm{E}-3$ \\
\hline
\end{tabular}

$3 \cdot$ 
Table 2.8

Concentrations of Radionuclides in Reactor Coolant at Point Beach Unit 1 on January 20, 1981

\begin{tabular}{llll}
\hline Isotope & $\mu \mathrm{CI} / \mathrm{mL}$ & Isotope & $\mu \mathrm{Ci} / \mathrm{mL}$ \\
\hline $\mathrm{I}-134$ & $4.54 \mathrm{E}-1$ & $\mathrm{I}-131$ & $3.10 \mathrm{E}-2$ \\
$\mathrm{Xe}-135$ & $3.29 \mathrm{E}-1$ & $\mathrm{Ar}-41$ & $8.83 \mathrm{E}-3$ \\
$\mathrm{Cs}-138$ & $2.78 \mathrm{E}-1$ & $\mathrm{Na}-24$ & $7.49 \mathrm{E}-3$ \\
$\mathrm{I}-135$ & $2.66 \mathrm{E}-1$ & $\mathrm{Kr}-85$ & $6.09 \mathrm{E}-3$ \\
$\mathrm{R}-88$ & $2.17 \mathrm{E}-1$ & $\mathrm{Cs}-137$ & $2.81 \mathrm{E}-3$ \\
$\mathrm{I}-132$ & $2.11 \mathrm{E}-1$ & $\mathrm{Mo}-99$ & $1.96 \mathrm{E}-3$ \\
$\mathrm{I}-133$ & $1.01 \mathrm{E}-1$ & $\mathrm{Cs}-134$ & $1.36 \mathrm{E}-3$ \\
$\mathrm{Kr}-88$ & $1.52 \mathrm{E}-1$ & $\mathrm{Te}-132$ & $8.74 \mathrm{E}-4$ \\
$\mathrm{Xe}-138$ & $1.37 \mathrm{E}-1$ & $\mathrm{Xe}-133 \mathrm{~m}$ & $1.71 \mathrm{E}-4$ \\
$\mathrm{Xe}-133$ & $1.34 \mathrm{E}-1$ & $\mathrm{La}-140$ & $1.58 \mathrm{E}-4$ \\
$\mathrm{Xe}-135 \mathrm{~m}$ & $9.26 \mathrm{E}-2$ & $\mathrm{Cs}-136$ & $1.16 \mathrm{E}-4$ \\
$\mathrm{Kr}-85 \mathrm{~m}$ & $9.22 \mathrm{E}-2$ & $\mathrm{Co}-58$ & $9.58 \mathrm{E}-5$ \\
$\mathrm{~F}-18$ & $6.94 \mathrm{E}-2$ & $\mathrm{Co}-60$ & $2.13 \mathrm{E}-5$ \\
$\mathrm{Kr}-87$ & $5.26 \mathrm{E}-2$ & $\mathrm{Mn}-54$ & $3.10 \mathrm{E}-6$ \\
& & $\mathrm{Fe}-59$ & $3.04 \mathrm{E}-6$ \\
& & & \\
\hline
\end{tabular}

\subsection{Activity Loading and Principal RNs on Resins for Disposal}

The surveys by $\mathrm{Lin}(1)$ and Clark(2) dealt mainly with performance of resins in treating liquid streams under nuclear power plant operating conditions. Our primary interest is in the effects of radiation both on resin performance and on properties of the resins after they leave the plants for final disposal. While we asked for activity levels in the liquid streams, as did Lin and Clark, we asked as well for the activity loadings on spent resins for disposal, which they did not. Thus any information they obtained on this subject was coincidental, and there is no section in their reports comparable to this one.

Table 2.9 summarizes information on the loadings of those resins with the highest activity levels in the plants listed. Table 2.10 lists the principal RNs on the resins as given by those plants answering the pertinent question. Tables 2.11-2.16 present analytical results from six plants which sent detailed analysis sheets giving a breakdown into individual RNs on the resins. These latter tables refer to reactor coolant cleanup resins, so it is likely that the data in Table 2.9 refer to similar resins. The actual analytical sheets are reproduced in Table $\mathrm{C}-1$ to $\mathrm{C}-8$ of Appendix $\mathrm{C}$.

Perhaps the most striking thing about the data in Table 2.9 is the large variability between the different plants, both BWRs and PWRs. The loadings, both maximum and typical, show more than a hundredfold variation (maximum loading from 0.3 to $60 \mathrm{Ci} / \mathrm{ft}^{3}$ and typical loadings from $<0.1$ to 
$\left.30 \mathrm{Ci} / \mathrm{ft}^{3}\right)$. Also, the distribution of the relatively long-lived RNs varies from largely activation products (Co-60, Mn-54, etc.) to largely fission products (Cs-134,137) (see Tables A.2 and A.3).

Table 2.9

Typical and Maximum Activity Loading

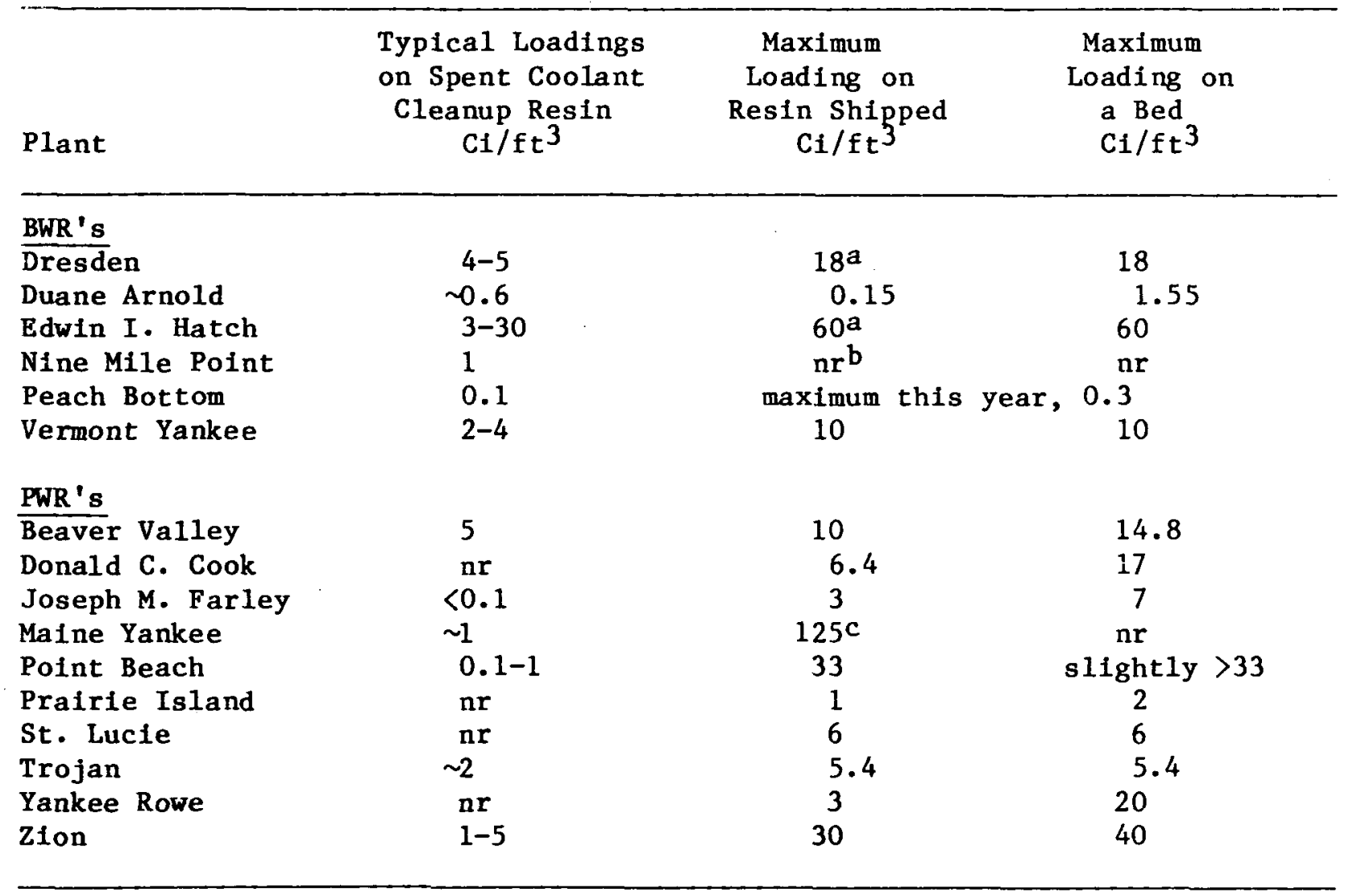

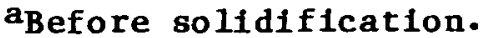

$b_{n r}$ - no response.

cMostly Co-58 (71-day half-11fe). 
Table 2.10

Principal Radionuclides on Resinsa

Plant

Principal Radionuclides

BWRs

Dresden

Edwin I. Hatch

Peach Bottom

Co-58,60; Mn-54; Cs-134,137.

Cs-134,137; Zn-65; Co-60.

Zn-65; Co-58,60; Cs-134,137; Cr-51; I-131; Mn-54.

Vermont Yankee

Cs-134, 137; Zn-65; Co-58,60; Zr-95; Mn-54.

PWRs

Donald C. Cook

Co-58,60; Cs-134,137; Mn-54; Sb-124.

Joseph M. Farley

Co-58,60; Mn-54; Cs-137; H-3.

Maine Yankee

Co-58,60; Mn-54; Cs-134,137; Sr-89,90.

Point Beach

Co-58,60; Cs-134,137; Sb-125; Ru-106; Mn-54; Cr-51.

Trojan

Co-58,60; Cs-134,137; Mn-54; Ce-144; Zn-65; Nb-95;

$\mathrm{Sb}-125$; Sr-90.

a Usually coolant cleanup resin, but not always specified.

Table 2.11

Levels of Radionuclides on Resin for

Shipment at Donald C. Cook on June 21, 1981

\begin{tabular}{ll}
\hline Isotope & $\mu \mathrm{CI} / \mathrm{mL}^{\mathrm{a}}$ \\
\hline Co-58 & $1.55 \mathrm{E}-1$ \\
$\mathrm{Co}-60$ & $5.48 \mathrm{E}-2$ \\
$\mathrm{Cs}-137$ & $1.44 \mathrm{E}-2$ \\
$\mathrm{Sb}-124$ & $8.88 \mathrm{E}-3$ \\
$\mathrm{Cs}-134$ & $8.87 \mathrm{E}-3$ \\
$\mathrm{Mn}-54$ & $8.03 \mathrm{E}-3$ \\
$\mathrm{I}-131$ & $3.43 \mathrm{E}-3$ \\
$\mathrm{Nb}-95$ & $1.04 \mathrm{E}-3$ \\
$\mathrm{Co}-57$ & $7.03 \mathrm{E}-4$ \\
\hline
\end{tabular}

al $\mathrm{Cl} / \mathrm{ft}^{3}=35.3 \mu \mathrm{CI} / \mathrm{mL}$. 
Some fission and activation products can be present at relatively high percentages at one plant, but not at others. For example, the activation product $\mathrm{Zn}-65$ is the predominant activation product at two plants, in one of which (E. I. Hatch, Table 2.12) fission products constitute the bulk of the activity, and in the other (Peach Bottom, Table 2.13) activation products predominate. In most other plants (Tables $\mathrm{A}-1$ and $\mathrm{A}-2$ ) $\mathrm{Zn}-65$ is not mentioned. Although Co-58 is normally present in smaller amounts than Co-60, it exceeds Co-60 at Dona1d C. Cook (Table 2.11) by a factor of 3, and at Ma1ne Yankee (Table 2.13) by a factor of nearly 20. In the case of fission products, Ce-144 is an example of one that is present in an amount comparable to Cs-134 and Cs-137 at Trojan (Table 2.15) but is not significant at most other plants.

Ta ble 2.12

Levels of Radionuclides on Unit 1 Coolant Cleanup Resin at E. I. Hatch.

\begin{tabular}{|c|c|}
\hline Is otope & $\mu \mathrm{Ci} / \mathrm{g}$ \\
\hline $\begin{array}{l}\mathrm{Cs}-137 \\
\mathrm{Cs}-134 \\
\mathrm{Zn}-65 \\
\mathrm{Co}-60\end{array}$ & $\begin{array}{ll}7.57 & \mathrm{E}+2 \\
5.46 & \mathrm{E}+2 \\
1.28 & \mathrm{E}+2 \\
3.01 & \mathrm{E}+1\end{array}$ \\
\hline
\end{tabular}

Ta ble 2.13

Levels of Radionuclides on Resin for Shipment at Maine Yankee on March 11, 1980

\begin{tabular}{ll}
\hline Isotope & $\mu \mathrm{C} 1 / \mathrm{g}$ \\
\hline Co-58 & $1.70 \mathrm{E}+2$ \\
Cs-137 & $2.11 \mathrm{E}+1$ \\
Cs-134 & $1.11 \mathrm{E}+1$ \\
Co-60 & $9.76 \mathrm{E} 0$ \\
\hline
\end{tabular}


Table 2.14

Levels of Radionuclides on Resin for Shipment at Peach Bottom

\begin{tabular}{lc}
\hline Isotope & \multicolumn{1}{c}{$\mu \mathrm{CI} / \mathrm{g}$} \\
\hline \multicolumn{1}{c}{ From Ana1ysis } \\
Zn-65 & $2.45 \mathrm{E} 0$ \\
Co-60 & $6.64 \mathrm{E}-1$ \\
Cs-137 & $4.06 \mathrm{E}-1$ \\
Cs-134 & $2.86 \mathrm{E}-1$ \\
Cr-51 & $2.06 \mathrm{E}-1$ \\
I-131 & $1.27 \mathrm{E}-1$ \\
Co-58 & $1.05 \mathrm{E}-1$ \\
La-140 & $2.60 \mathrm{E}-2$ \\
Mn-54 & $1.10 \mathrm{E}-2$ \\
Estimated (pure & $8-$ emitters) \\
Sr-90 & $4.06 \mathrm{E}-3$ \\
Fe-55 & $7.64 \mathrm{E}-1$ \\
Ni-63 & $5.98 \mathrm{E}-1$ \\
\hline
\end{tabular}

Ta ble 2.15

Levels of Radionuclides on Resin From Trojan on May 14, 1981

\begin{tabular}{ll}
\hline Isotope & $\mu \mathrm{CI} / \mathrm{g}$ \\
\hline Co-60 & $4.57 \mathrm{E}+1$ \\
$\mathrm{Cs}-137$ & $1.26 \mathrm{E}+1$ \\
$\mathrm{Cs}-134$ & $5.13 \mathrm{E} 0$ \\
$\mathrm{Mn}-54$ & $2.78 \mathrm{E} 0$ \\
$\mathrm{Co}-58$ & $5.32 \mathrm{E}-1$ \\
$\mathrm{Ce}-144$ & $3.49 \mathrm{E}-1$ \\
$\mathrm{Ru}-106$ & $1.95 \mathrm{E}-1$ \\
$\mathrm{Sb}-125$ & $1.65 \mathrm{E}-1$ \\
$\mathrm{Cr}-51$ & $1.21 \mathrm{E}-1$ \\
$\mathrm{Zn}-65$ & $6.71 \mathrm{E}-2$ \\
$\mathrm{Co}-57$ & $6.07 \mathrm{E}-2$ \\
$\mathrm{Fe}-59$ & $5.87 \mathrm{E}-2$ \\
$\mathrm{Ag}-110 \mathrm{~m}$ & $4.04 \mathrm{E}-2$ \\
$\mathrm{Nb}-95$ & $2.26 \mathrm{E}-2$ \\
$\mathrm{Sb}-124$ & $1.78 \mathrm{E}-2$ \\
$\mathrm{Ce}-141$ & $1.26 \mathrm{E}-2$ \\
& \\
\hline
\end{tabular}


Table 2.16

Levels of Radionuclides on Reactor Cleanup Resin at Vermont Yankee

\begin{tabular}{|c|c|}
\hline Isotope & $\mu \mathrm{Cl} / \mathrm{g}$ \\
\hline $\mathrm{Cs}-137$ & $4.84 \mathrm{E}+1$ \\
\hline Co-60 & $3.05 \mathrm{E}+1$ \\
\hline $\mathrm{Zn}-65$ & $2.03 \mathrm{E}+1$ \\
\hline $\mathrm{Cs}-134$ & $1.78 \mathrm{E}+1$ \\
\hline $\mathrm{Zr}-95$ & $1.11 \mathrm{E}+1$ \\
\hline$M n-54$ & $5.98 \mathrm{E} 0$ \\
\hline Co-58 & $5.88 \mathrm{E} 0$ \\
\hline$I-131$ & $5.35 \mathrm{E}-1$ \\
\hline Tc-99m & $4.19 \mathrm{E}-1$ \\
\hline
\end{tabular}

Variations of this nature are expected due to different operating conditions at different plants, and the long term radiation doses delivered to the resins by all of these other RNs is small (due to their shorter half-lives) relative to the dose from $\mathrm{Co}-60$ and $\mathrm{Cs}-137$. What is perhaps unexpected is the absolute magnitude of some of the maximum loadings reported, higher than $30 \mathrm{Ci} / \mathrm{ft}^{3}$ at 3 of the 16 plants. A fourth plant, Maine Yankee, reported $125 \mathrm{Cl} / \mathrm{ft}^{3}$ for the maximum loading on a resin for disposal, but this turned out to be due largely to $\mathrm{Co}-58^{*}$ whtch has a half-life of only 71 days and would thus require much higher loadings to cause significant radiation damage.

E. I. Hatch reported the highest loading of radioactivity with a halfIife $>5$ years. That loading $\left(60 \mathrm{Ci} / \mathrm{ft}^{3}\right)$ was composed largely of $\mathrm{Cs}-137$ and was therefore comparable to that encountered on a resin prefilter used in the AFHB cleanup at TMI-II. (8) The latter was loaded to approximately $40 \mathrm{C} 1 / \mathrm{ft}^{3}$, assuming uniform loading, and was considered to be loaded to a higher than desirable level in terms of then-known power plant practice, and from the point of view of radiation damage to the resin. The maximum loading on waste shipped from $\mathrm{E}$. I. Hatch would have been $<60 \mathrm{Ci} / \mathrm{ft}^{3}$ because of dilution when the resin was solidified. They ship only $100 \mathrm{ft}^{3} / \mathrm{yr}$ of coolant cleanup resin for each reactor, but $15,000 \mathrm{ft}^{3} /$ year, for each reactor, of their other resins, which are loaded to only $0.015-0.25 \mathrm{ci} / \mathrm{ft}^{3}$. Thus this plant could use many more times the amount of coolant cleanup resin than they present ly use (thereby conslderably reducing their loadings) without appreciably increasing their total resin use. Another acceptable way of reducing long-term dose to thelr resins might be to mix the coolant cleanup resins with some of the other resins before solidifying.

${ }^{*}$ D. R. Mackenzie and K. J. Swyler, Memo to File, March 1, 1982; "Report of Trip to Maine Yankee Atomic Power Plant, February 23, 1982." 
The other two plants reporting loadings $>30 \mathrm{Ci} / \mathrm{ft}^{3}$ are $\mathrm{Zion}$ and Point Beach, with 40 and approximately $33 \mathrm{cl} / \mathrm{ft}^{3}$ respectively for maximum loading on a bed. Since Zion solidifies for shipment, their maximum loading on shlpped waste would have been less than the reported $30 \mathrm{Ci} / \mathrm{ft}^{3}$ reported as maximum. Al1 the other plants report 10 or fewer $\mathrm{C} 1 / \mathrm{ft}^{3}$ as the maximum loading on a resin shipped to date. This includes Dresden, since their value of 18 is for the resin before dilution by solidification. Duane Arnold reported a maximum of $0.15 \mathrm{Ci} / \mathrm{ft}^{3}$ with an annual shipment of $6000 \mathrm{ft}^{3}$ and Peach Bottom $0.3 \mathrm{Cl} / \mathrm{ft}^{3}$. The others ( 9 out of 15 ) were all in the $1-10 \mathrm{Ci} / \mathrm{ft}^{3}$ range.

The maximum values reported were of ten termed unusually high for the particular plant, or were said to refer to a one-time shipment. Indeed, 1-10 Ci/ $\mathrm{ft}^{3}$ is more typical of the loadings encountered in practice, e.g., 7 out of the 12 plants for which information is available gave figures in this range (Table 2.9). Four plants have typical loadings that are even lower, and even E. I. Hatch, the only plant reporting $>10 \mathrm{Cl} / \mathrm{ft}^{3}$ for normal shipment gives a range of $3-30 \mathrm{Ci} / \mathrm{ft}^{3}$. It can be concluded, then, that U.S. commercial reactors typically ship coolant cleanup resin in the range of $1-10 \mathrm{Cl} / \mathrm{ft}^{3}$ or less, but occasionally a few may significantly exceed $10 \mathrm{Ci} / \mathrm{ft}^{3}$.

\subsection{Sr-90 in Power Plant Wastes}

For routine analysis most power plants determine the $\beta, \gamma$-activity in liquid and resin samples by $\gamma$-counting, of ten with energy analysis to identify and measure the individual RNs (see, for example, Tables $2.11-2.15$ ). This counting technique is very convenient, and particularly sulted to routine analysis. However, it completely misses the pure B-emitter Sr-90 (29 yr half1ife) and its short-lived daughter (2.7 day half-life) $Y-90$, an almost pure $\beta$-emitter. Because of its high $\beta$-energy (2.28 MeV maximum energy), Y-90 is responsible for most of the radiation damage, toxicity, etc. from the Sr, $\mathrm{Y}-90$ couple when they are in secular equilibrium: Curie for curle, Sr,Y-90 delivers approximately twice the long-term dose delivered by $\mathrm{Cs}_{8}-137$. It is thus essential to know the $\mathrm{Sr}-90$ loading on a resin in order accurately to determine long-term dose.

In the responses to our questionnalre, three plants mentioned Sr-90 Trojan, Peach Bottom and Maine Yankee. Trojan and Maine Yankee list it as one of the principal RNs on spent resin (see Table 2.10). Trojan submitted an analysis done in July 1981 by Science Applications, Inc., which found $0.32 \mu \mathrm{Cl} \mathrm{Sr}-90 / \mathrm{g}$ in a resin sample containing $12.6 \mu \mathrm{Cl} \mathrm{Cs}-137 / \mathrm{g}$. The Sr-90 content thus amounted to $2.5 \%$ of the $\mathrm{Cs}-137$ in the sample. Analytical results from Peach Bottom gave an estimated value for Sr-90 exactly $1 \%$ of that for Cs-137. When asked about this, personnel at Peach Bottom stated that they analyzed samples periodically for $\mathrm{Sr}-90$, and the amount has never exceeded $1 \%$ of the Cs-137 present. They, therefore, use that value routinely as a conservative estimate which they are confident will not be exceeded. Possible requirements, as a result of this kind of experience, for dealing with a maximum loading regulation, are discussed in Section 3.4.3. 


\subsection{TRU Isotopes on Spent Resins}

The questionnaire requested information on a-activity in the liquid streams and on spent resin. Most respondents either did not answer these questions (11) or indicated that any a-activity was below minimum detectable levels (8). Four plants had measurable amounts of $\alpha$-activity associated with resins, Kewaunee, Millstone, Maine Yankee and Trojan.

Kewaunee and Millstone reported concentrations in the liquid streams to be less than the mintmum detectable, and noted that the $\alpha$-activity on their resins was $<10 \mathrm{nCi} / \mathrm{g}$. Maine Yankee gave $\langle 1 \mu \mathrm{Ci} / \mathrm{mL}$ for the a-activity associated with resins. Since $1 \mu \mathrm{Ci} / \mathrm{mL}$ is many times higher than the $10 \mathrm{nCi} / \mathrm{g}$ TRU limlt, personnel at Malne Yankee were questioned about their response. They stated that our questionnaire asked for $\mu \mathrm{Cl} / \mathrm{mL}$, and they gave the value " $<1$ " to indicate that their activity was not in the $\mu \mathrm{Cl} / \mathrm{mL}$ range. In fact, it was barely detectable and levels were well below $10 \mathrm{nCl} / \mathrm{g}$ on all resins shipped for disposal.

Trojan sent a copy of a typical recent analysis, which is reproduced in Appendix $D$ as Table $D-1$. The data are presented in Table 2.17 in terms of $\mathrm{nCi} / \mathrm{g}$. Since the concentration of TRU isotopes on the resin sample was approximately $14 \mathrm{nCi} / \mathrm{g}$, the resin would be technically TRU waste, being above the $10 \mathrm{nCi} / \mathrm{g}$ TRU limit. Trojan disposes of its spent resins by solidification, so that for this particular batch, its a-activity after solidification was $4.6 \mathrm{nCi} / \mathrm{g}$ of solid waste, well below the TRU limit. So far all their resin wastes have had no trouble meeting the requirements of non-TRU waste.

Table 2.17

Alpha Emitting Nuclide Levels on a Filter and a Resin Sample at Trojan

\begin{tabular}{lcc}
\hline \multicolumn{1}{c}{ Nuclides } & $\begin{array}{c}\text { Amount on filter } \\
\text { nC1 Total }\end{array}$ & $\begin{array}{c}\text { Concentration on Resin } \\
\mathrm{nC1} / \mathrm{g}\end{array}$ \\
\hline $\mathrm{Pu}-239,240$ & 1.31 & 11.4 \\
$\mathrm{Pu}-238$ & 0.58 & 3.0 \\
$\mathrm{Am}-241$ & $0.015 \ldots .060$ \\
$\mathrm{Cm}-242,243$ & 0.051 & 0.073 \\
$\mathrm{Cm}-244$ & 0.004 & 0.006 \\
\hline
\end{tabular}

On the basis of the responses to the survey, it can be concluded that levels of TRU 1sotopes on spent resins from commercial reactors are very low, efther below $10 \mathrm{nCi} / \mathrm{g}$ of resin, or of such a value that the level in the final waste form can easily be kept below $10 \mathrm{nCl} / \mathrm{g}$ so that the waste does not constitute TRU waste. Such levels of a-activity produce radiation doses to the resin that cause insignificant amounts of damage. 


\subsection{Disposal Information}

\subsubsection{Methods}

The plants responding to the questionaire used a wide range of disposal methods, from shipping dewatered resin in containers of approximately $6 \mathrm{ft}^{3}$ (55-gal drums) to $200 \mathrm{ft}^{3}$ (steel liners), to solidifying in 55-gal drums and larger steel container. Several plants contracted out all their resin disposal to commercial firms, which normally solidify, so presumably the resins from these plants are being solidified. A fair proportion indicated they planned to use HIC's for disposing of dewatered resin. The plants which did their own solidification generally used cement.

The solidification option is useful for plants where activity levels are high (either $\beta, \gamma$, as considered in Section 2.3, or $\alpha$, as considered in Section 2.5). The dilution occurring during solidification makes the resultant waste less of an exposure risk for workers if $B, \gamma$-activity is involved, or can keep the final product from being classed as TRU waste if a-activity is the limiting factor. This idea should not be carried too far, but the published information indicates that composites of resin with cement, for example, do not suffer any deleterious affects from irradiation to doses of between $10^{8}$ and $10^{9} \mathrm{rad} .(5)$ Doses of $10^{8} \mathrm{rad}$ to a composite containing $50 \%$ resin by volume would require a $\mathrm{Cs}-137$ loading in the range of $30-$ $40 \mathrm{Ci} / \mathrm{ft}^{3}$ on the original resin, depending on the size and shape of the composite waste form.

\section{6 .2 Amounts}

There is a very wide variation in amounts of spent resin shipped annually per reactor. The values reported in the survey are given in Tables A.I and A.2. BWRs in general report shipping ten or more times as much as PWRs. Amounts from BWRs ranged from 1,000 to $25,000 \mathrm{ft}^{3}$, except for Dresden which reported only $300 \mathrm{ft}^{3}$. For PWRs, amounts were mostly 100 to $300 \mathrm{ft}^{3}$, with only Zion reporting an amount (5,000 to 10,000 $\left.\mathrm{ft}^{3}\right)$ typical of a BWR. Of those shipping waste with radionuclide loadings of $10 \mathrm{Ci} / \mathrm{ft}^{3}$ or greater, several plants had low total shipments, including Dresden, the only BWR reporting a low amount shipped. The remaining three plants shipped large amounts. It has already been mentioned (Section 2.3) that Edwin I. Hatch reported shipping $100 \mathrm{ft}^{3} / \mathrm{yr}$ of reactor coolant cleanup resin out of a total annual shipment of $15,000 \mathrm{ft}^{3}$. Two other plants, Zion (PWR) and Vermont Yankee (BWR) reported shipping several thousand $\mathrm{ft}^{3}$ annually. They did not give a breakdown to indicate the amount of coolant cleanup resin shipped. 


\section{SELECTION OF A MAXIMUM PERMISSIBLE LOADING}

NRC in a recent draft branch technical position (BTP) for guidance to waste generators proposed setting a maximum of $10 \mathrm{Ci} / \mathrm{ft}^{3}$ for the RN loading on organic ion exchange resins being shipped for disposal. At this loading of Cs-137, a long-term dose of approximately $10^{8}$ rad would be delivered to the resin. In this section, the rationale for choosing $10 \mathrm{ci} / \mathrm{ft}^{3}$ maximum loading is examined, and it is concluded that it is desirable for relatively longlived RNs such as $\mathrm{Cs}-137$ and $\mathrm{Sr}-90$. However, because of the variation in disintegration energy and half-life (and therefore in total dose delivered) of the RNs found on waste resins in practice, the $10^{8}$ rad total dose limit is considered a more appropriate basis for a guideline.

\subsection{Need for a Loading Limit}

Ion exchange resins suffer degradation on exposure to sufficiently high doses of radiation. Such degradation results from damage to the polymer structural framework and removal of functional groups by radiation decomposition reactions. The former causes formation of hydrogen and other gases. The latter can cause not only gas formation, but loss of exchange capacity, and changes in $\mathrm{pH}$ which might enhance corrosion of metal containers. Also radiolytic decomposition of the water remaining in dewatered resins produces gas, as well as reactive radicals capable of attacking the polymer structure and functional groups. These effects should obviously be avoided in wastes for consignment to a burial site, hence the need for an upper loading limit below which their magnitude will be insignificant.

It must be realized that effects due to loading with the RNs commonly encountered at power plants will take a relatively long time to show up at realistic loading levels, $1 . e .$, at levels low enough to permit normal handiing and not lead to problems with worker exposure during handling. The spent resins are not stored for long periods (maximum about a year, and sometimes not at all) at nuclear power plants. Therefore, the total absorbed dose will not be large, and possible damage will not yet be apparent, before the resins are shipped for disposal. It is only after a perlod of many years that total dose to the resins will reach the stage where radiation damage would be obvious, in other words, long after the resins have been deposited at the burial site. In the case of $\mathrm{Co}-60$; for example, in one year only $12 \%$ of the eventual total dose will be delivered, whtle for Cs-137 the amount will be only $2.4 \%$, and even for Co-60 it will take over 5 years to reach $50 \%$ of the eventual total dose.

\subsection{Literature Information on Radiation Damage}

On the basis of information in the 1iterature survey of Gangwer, Goldstein and Pillay, (4) polymerization-type resins apparently are superior to condensation-type resins in terms of chemical, mechanical and thermal properties, although their radiation stablifty is not as great. In discussions with nuclear power plant personnel during preparation of our questionnaire, the point was made that utilities choose resins for plant operations that will 
provide them with maximum use, or service time. That means presumably, that their choice would normally be polymerization-type with its better chemical, mechanical, and thermal properties. Radiation stabllity is not an important factor during service so it will not be the criterion on which the choice is based.

The results of the survey confirm this, and we conclude that the resins used throughout the nuclear power industry are the strong acid cation exchangers (with sulfonic acid functional groups) and the strong base anion exchangers (with quaternary ammonium ion functional groups). Extent of crosslinking of the polystyrene with divinylbenzene (DVB) in cation exchangers varies from 4-16\% in commercially avallable resins, and the power plants appear to use mainly 8 or $10 \%$ cross-linked material. For purposes of this report then, these particular resins are the ones for which information on radiation damage is most desired, and the ones which must be considered the most important in determining a maximum loading requirement.

\subsubsection{General Principles}

Exact mechanisms to explain the interaction of radiation with different types of organic ion exchange resins have not been determined, due in large part to the great complexity of the polymer systems. (4) However, in a qualitative way, the kinds of chemical bonds attacked and the relative degrees to which different types of chemical reactions occur are known. Also, physical and chemical changes as a result of irradiation of the resins are reasonably well known in terms of changes in resin properties.

The principal types of bonds attacked in the resin molecules are: the $\mathrm{C}-\mathrm{C}$ bonds in the polymer structural framework, the bonds linking the functional groups to the carbon framework, and the $\mathrm{C}-\mathrm{H}$ bonds. The bonds linking functional groups to carbon atoms are the most susceptible to breakage. Scission of these bonds leads to loss of exchange capacity. Scission of C-C bonds leads to degradation of the polymer chains and to breakage of crosslinks, thereby partially breaking down the three-dimenstonal structural network. All these processes are destructive of the resin molecules, leading to undesirable changes in properties. Sclssion of $\mathrm{C}-\mathrm{H}$ bonds leads to formation of hydrogen gas (not destructive in itself) and to a certain amount of cross linking (constructive rather than destructive). This latter process therefore mitigates to some extent the damage done by other processes, but the overall effect of radiation is deterioration of the resin. This is particularly true in the presence of water and air, when oxidative processes also occur.

Some of the properties and the differences in susceptibility of the different types of resins are noted below. These are, however, broad generalizations, and there will undoubtedly be exceptions.

1. Most cation exchangers begin to show significant damage at a dose of around $10^{8} \mathrm{rad}$, while most anion exchangers are damaged noticeably at a somewhat lower dose. The one type of resin with a 
much greater radiation resistance (an anion exchanger with pyridine groups in the structural framework) is not used by power plants as far as is known.

2. The effects of radiation which are of most concern to disposal of spent resins are: gas generation, changes in $\mathrm{pH}$, agglomeration, enhancement of corrosion of metals in contact with the resins, and, to a lesser extent, loss of exchange capacity.

3. Larger changes in properties (up to a factor of five greater) are observed when resins are irradiated in the presence of water than when they are irradiated dry. The stabilities of the polystyrenedivinylbenzene resins irradiated in the presence of water show the following order:

pyridine based anion exchanger $>$ nuclear sulfonic and carboxylic cation exchanger $>$ weak base anion ex-

changers of the primary, secondary, and tertiary type $>$ strong base anion exchanger of the quaternary ammonium type.

4. In general, the salt forms of both cation and anion exchangers are more resistant to radiation than are the $\mathrm{H}^{+}$and $\mathrm{OH}^{-}$forms.

5. There appears to be no difference in irradiation effects between the different types of low $L_{E T}{ }^{*}$ radiation sources ( $X$-rays, $\gamma$-rays, fast electrons, and $\beta$-particles) as regards either differences in the nature of the radiation (wave vs particle) or whether the irradiation is internal or external ( $\beta$-particle vs the remainder).

\subsubsection{Effect on Exchange Capacity}

The exchange capacity of a resin is a measure of the extent to which it can remove lons from solution, and is expressed as milliequivalents per gram of resin. For the strong acid cation exchanger of most interest to this report, absorption of radiation causes cleavage of sulfonic acid groups. The result is formation of $\mathrm{SO}_{2}$ and consequent loss of the exchange capacity which the $\mathrm{SO}_{3} \mathrm{H}^{-}$groups had provided. In the presence of oxidants; some carboxylic acid and phenolic $\mathrm{OH}$ groups will be formed, and at low doses total exchange capacity: (TEC) :-due to these groups plus. the sulfonic acid groups may increase slightly. 'However, at higher doses, the net result is overall loss of TEC.

Although the qualitative picture seems clear, experimental results have not generally yielded quantitative interpretation of the data so as to enable

\footnotetext{
${ }^{\star} L E T$, or linear energy transfer, refers to the denstity of energy deposition along a particle path.
} 
differences between the results of different studies to be explained. (4) For example, several workers found that radiation resistance, as measured by loss of TEC, increased with increasing degree of cross-1inkage of the starting material. However, Tulupov et al. (10) reported no significant change in radiation stability of the resin $\mathrm{KU}-2$--again measured by TEC--going from $8 \%$ to $24 \%$ cross-1inkage.

Results of a study(11) of the effect of cross-linkage of Dowex 50 on loss of sulfonic acid groups are summarized in Table 3.1. This shows the variation in G-value for loss of $\mathrm{SO}_{3} \mathrm{H}^{-}$groups with dose for four degrees of cross-1inkage from $4 \%$ to $16 \%$. (G-value is defined as the number of radicals or molecules formed or decomposed per $100 \mathrm{eV}$ absorbed.) The resin stability increases (1.e., G-value for loss of $\mathrm{SO}_{3} \mathrm{H}^{-}$decreases) from $4 \%$ cross-linkage to $12 \%$ and then decreases at $16 \%$, except for the highest dose of nearly $10^{9} \mathrm{rad}$. For any degree of cross-11nkage, the G-value decreases with dose.

Table 3.1

G-Value for Loss of Sulfonic Acid Groups as a Function of Dose for Dowex 50 of Various Cross-Linkages(12)

\begin{tabular}{lllll}
\hline & \multicolumn{2}{c}{ G-value, Number of $\mathrm{SO}_{3} \mathrm{H}^{-}$} & Groups/100 $\mathrm{eV}$ \\
\cline { 2 - 5 } $\begin{array}{l}\text { Dose } \\
(\mathrm{rad})\end{array}$ & $\begin{array}{l}\text { Dowex } \\
50 \times 4\end{array}$ & $\begin{array}{l}\text { Dowex } \\
50 \times 8\end{array}$ & $\begin{array}{c}\text { Dowex } \\
50 \times 12\end{array}$ & $\begin{array}{c}\text { Dowex } \\
50 \times 16\end{array}$ \\
\hline $2.2 \times 108$ & 3.2 & 2.0 & 1.5 & 2.4 \\
$4.7 \times 10^{8}$ & 1.7 & 1.3 & 1.3 & 1.5 \\
$8.6 \times 10^{8}$ & 1.4 & 1.1 & 1.0 & 1.0 \\
\hline
\end{tabular}

The point that is of concern to this report, however, is the high G-values observed for all the cross-linkages at the lowest dose of $2 \times 10^{8}$ rad. Another, perhaps simpler, way of expressing the extent of this radiation damage is to present it in terms of percent loss of exchange capacity. $\mathrm{Re}^{-}$ sults of several studies using. Dowex 50, Amberlite IR-100, and Dowex $50 \mathrm{~W}$ showed that at a dose of $10^{8}$ rad approximately $5-10 \%$ of the exchange capacity was lost. $(12-14)$

Anion exchangers also lose capacity on irradiation. An effect somewhat analogous to that occurring with cation resins is observed with strong base anion exchangers, in that at low doses TEC is lost only slowly because some of the quaternary ammonium groups attacked are converted to weakly basic amino groups. However, with increasing dose net TEC decreases. As with cation exchangers, presence of water and salts exerts a fairly large effect, but again the spread in experimental results is too great to permit satisfactory interpretation of the observed effects. 
G-values for loss of anion exchange capacity are found largely in the Russian literature. (4) They are comparable to, but generally higher than, those for the strong acid cation resins. In terms of percentage loss of exchange capacity on Irradiation, Kazanjlan et al. (15) with the strong base anton resin Dowex-1 found decreases in capacity of well over $10 \%$ at $10^{8} \mathrm{rad}$. In fact, the decrease normally was considerably greater than that, and about double that observed for Dowex 50 strong acid cation exchanger. Thus, overall, it must be concluded that both anion and cation exchangers are quite susceptible to radiation damage as indicated by 1 oss of exchange capacity.

\subsubsection{Gas Generation}

Somewhat less work has been reported on gas generation during resin irradiation than on the loss of exchange capacity. Most of the results reported are for cation exchangers. (4) In particular, Mohorcic et al. $(16,17)$ and Kazanjlan and Horrell (18) have made quantitative determinations of the different gaseous products formed during radiolysis. of the few published results for anion exchange resins, those of Kazanjian(15) give quantitative estimates of the gaseous products.

The principal gases formed during irradiation of resins are hydrogen and carbon dioxide. Other gases reported to be formed from cation exchange resins are $\mathrm{CO}, \mathrm{SO}_{2}, \mathrm{O}_{2}$, and $\mathrm{CH}_{4}$, and from anion exchangers, $\mathrm{CO}, \mathrm{N}_{2}$, $\mathrm{NH}_{3}, \mathrm{~N}_{2} \mathrm{O}$, and NO. G-values for formation of several of the gases are given in Table 3.2. The G-values are noticeably much smaller than those for loss of exchange capacity, except for samples immersed in water or $7 \mathrm{M} \mathrm{HNO}_{3}$. For cation exchangers in water, $\mathrm{G}\left(\mathrm{H}_{2}\right)$ is between 1 and 2 and $\mathrm{G}\left(\mathrm{CO}_{2}\right)$ is 0.4. For anion exchange resin in $7 \mathrm{M} \mathrm{HNO}_{3}, \mathrm{G}\left(\mathrm{CO}_{2}\right)$ is 0.6 . In general, G-values for formation of hydrogen are 0.1 or $1 \mathrm{ess}$, and those for the other

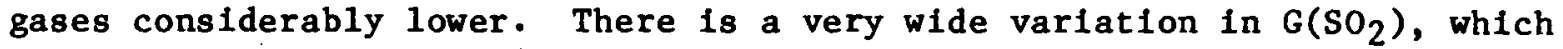
is not readily explainable by an obvious factor such as solubility of $\mathrm{SO}_{2}$ in the water of the resin matrix. Ylelds of the other gases normally are smaller when the resins are irradiated dry. Irradiation of cation resin in the salt form ( $\mathrm{Na}^{+}$and $\mathrm{Li}^{+}$) did not seem to make an appreciable difference, except for the $\mathrm{LI}^{+}$form in the dry state, where the G-values obtained for all gases except $\mathrm{SO}_{2}$ were lower than under any other conditions.

The amounts of $\mathrm{H}_{2}, \mathrm{CO}_{2}$, and $\mathrm{CO}$ formed by radiolysis are all approximately 1inear with dose to total doses $>10^{8}$ rad. This is shown in Figure 3.1 for $\mathrm{H}_{2}$ production from $10 \%$ cross-linked Dowex 50w: cation resin.(16) The data for this figure are taken directly from Reference 16 since several of the plots In Figure 11 of Gangwer, Goldstein, and P11lay (4) are incorrectly reproduced from the original. The $\mathrm{Li}^{+}$form was found to be somewhat less stable than the $\mathrm{H}^{+}$form when swollen with water, but slightly more stable when immersed in water. The data for immersion in water cannot be conveniently plotted on the same graph because the ylelds are so much higher.

There is an extremely large difference reported in $\mathrm{H}_{2}$ yield (factor of 100 - Table 3.2 and Figure 3.1) between the $\mathrm{Li}^{+}$form dry and swollen. This difference is difficult to understand, for one thing because the difference between the $\mathrm{H}^{+}$form dry and swollen is roughly a factor of 3 . Such a 
magnitude is not unexpected in view of the additional $\mathrm{H}_{2}$ production from radiolysis of the water in the matrix of the swollen resin. This published report of extreme suppression of $\mathrm{H}_{2}$ production in the dry $\mathrm{Li}^{+}$form thus appears to be suspect, especially since $\mathrm{Li}^{+}$does not suppress $\mathrm{H}_{2}$ produc-... tion in the moist resin, and the yields of the other gases are not greatly different between the $\mathrm{Li}^{+}$form dry and swollen. Aside from this one anomalous result, the data reported seem quite acceptable.

Table 3.2

\begin{tabular}{|c|c|c|c|c|c|c|c|}
\hline \multicolumn{8}{|c|}{$\begin{array}{l}\text { G-Values for Gasecus Product Fonmation During the } \\
\text { Radiation Decomposition. of Ion Exchange Reginga }\end{array}$} \\
\hline Resin & Ionic Porm & $\begin{array}{l}\text { Irradlation } \\
\text { Condltion }\end{array}$ & $G\left(H_{2}\right)$ & $\mathbf{G}\left(\mathrm{SO}_{2}\right)^{\mathbf{b}}$ & $\mathrm{G}\left(\mathrm{CO}_{2}\right)$ & $G(\infty)$ & Ref. Mo. \\
\hline Dowex $50 w \times 4$ & $\mathrm{H}^{+}, \mathrm{Na}^{+}$ & $\begin{array}{l}\text { Air-dry and } \\
0.1 \times \text { ( } \mathrm{HC} 1)\end{array}$ & 0.1 & - & - & - & 19 \\
\hline Dowex 50w $\times 10$ & $\mathrm{u}^{+}$ & Dry & 0.026 & 0.087 & 0.035 & 0.009 & 17 \\
\hline Leo-Kar b $215^{b}$ & $\mathrm{H}^{+}$ & Dry & 0.051 & 0.001 & 0.019 & - & 17 \\
\hline Dowex sow $\times 10$ & $\mathrm{u}^{+}$ & $12-47 x$ water & $\begin{array}{l}0.04 \text { to } \\
0.12\end{array}$ & -0.14 & -0.023 & -0.022 & 18 \\
\hline Dowex 50w $\times 10$ & $\mathrm{LI}^{+}$ & Dry & 0.001 & 0.26 & 0.07 & 0.002 & 17 \\
\hline Dowex 50w $\times 10$ & $\mathbf{L I}^{+}$ & Swollen & 0.11 & 0.5 & 0.008 & 0.020 & 17 \\
\hline Dowex 50w $\times 10$ & $\mathbf{H}^{+}$ & Swol lan & 0.095 & 0.006 & 0.019 & 0.027 & 17 \\
\hline Zeo-Kar b $215^{c}$ & $\mathrm{H}^{+}$ & Swollen & 0.12 & 0.005 & 0.046 & 0.005 & 17 \\
\hline Zeo-Karb $215 \mathrm{c}$ & $\mathrm{H}^{+}$ & $\begin{array}{l}\text { Immersed in } \\
\text { water }\end{array}$ & 1.7 & 0.002 & 0.43 & - & 17 \\
\hline Dowex 50 w $\times 10$ & $\mathbf{u}^{+}$ & $\begin{array}{l}\text { Immersed. In } \\
\text { water }\end{array}$ & 1.7 & - & 0.41 & -- & 17 \\
\hline Dorrex $50 \mathrm{~N} \times 10$ & $\mathrm{Li}^{+}$ & $\begin{array}{l}\text { Immersed in } \\
\text { water. }\end{array}$ & 1.3 & - & 0.41 & - & 17 \\
\hline Dowex $1 \times 4$ & $\mathrm{NO}_{3}-$ & A1r-dry & 0.09 & - & - & 0.002 & 16 \\
\hline Powex $1 \times 4$ & $\mathrm{NO}_{3}^{-}$ & In 78 HNO3 & 0.02 & -- & 0.6 & - & 16 \\
\hline
\end{tabular}




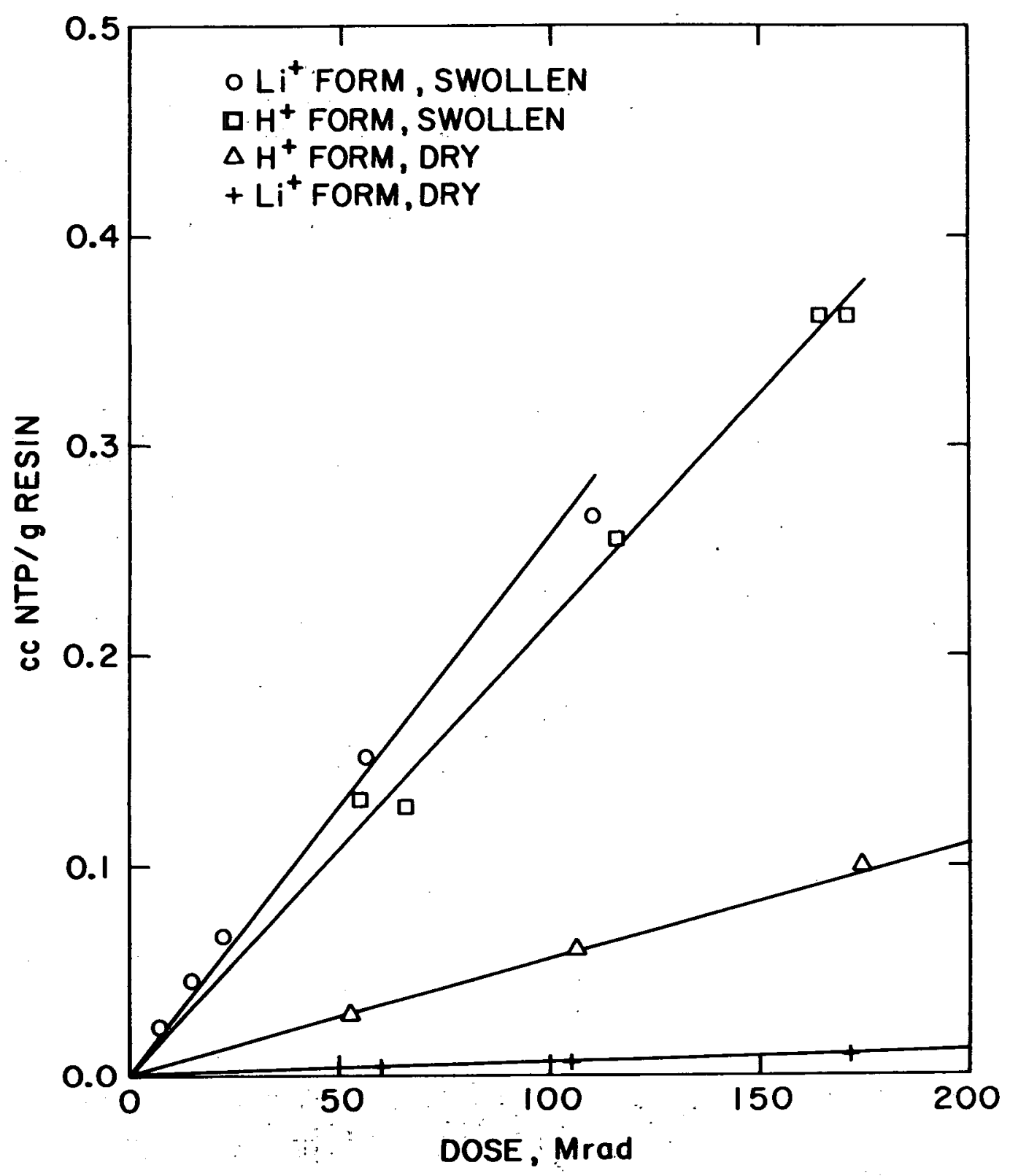

Figure 3.1 Hydrogen production from 1rradiation of $10 \%$ cross-linked Dowex 50W. Résults reported by Mohorcic and Kramer, (16) 1968. 


\subsubsection{Work Related to TMI-II Cleanup}

Recent work (5-8) in connection with the TMI-II cleanup program has been mentioned in the introduction. This work has provided useful information on the effects of radiation to total doses $>10^{9}$ rad on various properties of the resin types used by the nuclear power industry. The effect on exchange capacity has not been Investigated, but gas generation, change in pH, and several other chemical and physical properties have been studied.

\subsubsection{Gas Generation}

In discussion of gas generation during irradiation, it should be pointed out that, while there is a net formation of gaseous products, there is a considerable decrease in the amount of any oxygen present. According to work at BNL (5) on effects of irradiation on the resins used in the cleanup of TMI-II contaminated water, this oxygen depletion is quite rapid in the earlier stages. Thus in the experimental air irradiations of the proprietary formulation given the name D-mix, both by itself and incorporated in a solidified form with cement, an intitial pressure decrease was observed. Although the gas over the sample was not analyzed during this period, almost no oxygen was left at the end of the irradiations, and oxygen consumption presumably was responsible for the initial pressure drop. This effect was not observed in the earlier work reviewed by Gangwer et al., (4) and of course it would not occur in irradiations in vacuum or under an inert gas cover. However, generation of oxygen is not repored for cation exchange resins by most workers, and not at all for anton exchange resins, and this lack of oxygen production is compatible with the oxygen depletion observed in BNL's irradiation in the presence of atr.

In the TMI-II related work, gas generation was studied at $\operatorname{BNL}(5,8)$ and by McFarland. $(6,19)$ Hydrogen and methane were observed by BNL $(8)$ on Irradiation of the nuclear grade cation exchanger IRN-77. No spectal study of individual gas yields was carried out. In the experiments described in the last paragraph in which oxygen depletion was observed, BNL measured the amounts of $\mathrm{H}_{2}, \mathrm{CH}_{4}$ and $\mathrm{CO}_{2}$ formed. (5) The values obtained were useful for comparative purposes only, since the resin irradiated was a proprietary formulation. MCFarland irradiated the cation exchanger Dow $\mathrm{HCR}-\mathrm{S}, \mathrm{Na}^{+}$form, and the anion exchanger Dow $\mathrm{SBR}-\mathrm{OH}, \mathrm{BO}_{3}-3$ form, to high doses in an experiment where bulldup of gas pressure was followed.(19) Pressures were incorrectly converted to moles (or volumes) because of inaccurate estimation of void space in the experimental systems. Subsequent work ${ }^{(6)}$ enabled determination of the void space and correction of the volumes produced at STP.

The pressure plots are reported in Figures 7 and 8 of Reference 6 . The data for both resins below $1.6 \times 10^{9}$ rad are plotted on one diagram in F1gure 3.2. Although these yield-dose curves of McFarland are nearly linear, as were those of earlier workers, there are definite increases in the slopes as one goes to higher dose. The data show that the anion exchanger exhibits a rate of gas production several times that of the cation exchanger (about 8 times when the larger vold volume in the anion capsules is taken into 
account). Both plots indicate a threshold for gas production somewhere around $5 \times 10^{7} \mathrm{rad}$. This is contrary to the results in the literature reviewed by Gangwer, Goldstein, and Pillay, (4) and, in fact, McFarland's plots of yielddose curves for hydrogen and methane do not show a threshold. The threshold for pressure bulldup is most likely due to the oxygen depletion effect observed by BNL, and $1 t$ is significant in this regard that pressures in the BNL experiments, after their initial decrease, returned to their original values and began to increase at a dose in the vicinity of $5 \times 10^{7} \mathrm{rad}$.

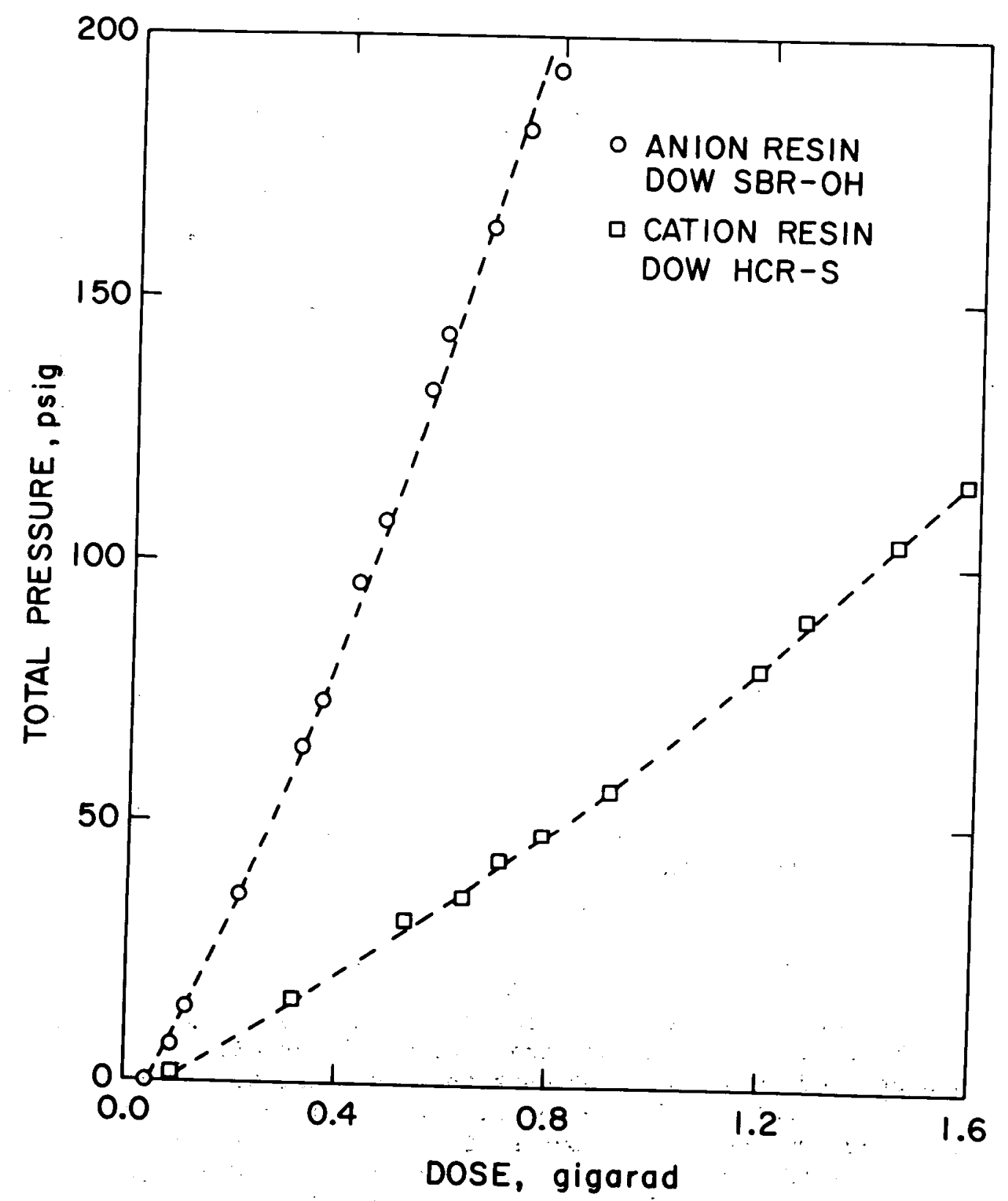

Figure 3.2 Gas pressures developed on irradiation of cation and anton resins. Results reported by McFarland, (6) 1981. 
The gas in McFarland's experiments was analyzed at the end of the irradiations. In Table 3.3, results are given for the anion exchanger as reported in Table 5 of Reference 6 . The results given for the cation exchanger in Table 3.3 were taken from the same source, but adjusted downward to the same dose $\left(7.9 \times 10^{8} \mathrm{rad}\right)$ as the anion resin had recelved. For the ad justment, the actual experimental curve of pressure vs dose given in Figure 3.2 was used. The distribution of gases for the two resins is simtlar, but the overall amounts are much greater for the anion resin--almost a factor of eight for total gas.

Table 3.3

Yielde of Product Gesega Prow $7.9 \times 10^{8}$ rad Irradiation of Dewatered Cation and Anton Exchange Rasio Geo Volume, cc/s Resin

\begin{tabular}{|c|c|c|c|c|c|c|c|c|c|}
\hline Resin & Total Gas & $\mathrm{H}_{2}$ & $\mathrm{CO}_{2}$ & CD & $\mathrm{CH}_{4}$ & $0_{2}$ & $N_{2}$ & $\begin{array}{l}\text { Sulfut Ganes } \\
\text { WB } 8 / 8 \text { Resin }\end{array}$ & $G_{\text {total }}$ \\
\hline $\begin{array}{l}\text { Cation }-\mathrm{Na}^{+} \text {form } \\
\text { of Dow } \mathrm{HCR}^{-\mathrm{S}} \\
\text { Ant on }-\mathrm{BO}_{3}-3 \text { form } \\
\text { of Dow SBR-OH }\end{array}$ & $\begin{array}{r}1.7 \\
12.6\end{array}$ & $\begin{array}{r}0.70 \\
6.8\end{array}$ & $\begin{array}{l}0.21 \\
1.1\end{array}$ & $\begin{array}{l}0.25 \\
1.3\end{array}$ & $\begin{array}{l}0.03 \\
0.81\end{array}$ & $\begin{array}{l}0.18 \\
0.56\end{array}$ & $\begin{array}{c}- \\
0.68\end{array}$ & $\begin{array}{c}0.02 \\
-\end{array}$ & $\begin{array}{l}0.09 \\
0.68\end{array}$ \\
\hline
\end{tabular}

The G-values for total gas are also given in Table 3.3. They agree reasonably well with the results of work reported in the last section (3.2.3). The G-value for $\mathrm{H}_{2}$ production for the anton exchanger at $10^{8}$ rad $(0.15)$ is a bout double that of Kazanjian's(15) for dry Dowex-1, which is a reasonable difference between moist and dry resins. The result for the cation exchanger is close to that for Mohorcic's $(16)$ dry Dowex $50 \mathrm{~W}$ in the $\mathrm{H}^{+}$form, and much lower than that for the swollen Dowex 50w in the $\mathrm{H}^{+}$form. This could be due to McFarland's resin being in the $\mathrm{Na}^{+}$form and/or differences in the amount of water present in the resins in the two studies.

\subsubsection{Changes in Appea rance}

Several effects have been observed, such as swelling and agglomeration, which are probably partly physical and partly chemical in nature. Swelling was studied by a number of workers, and their work reviewed by Gangwer et al.(4) Swelling and shrinking effects are best observed in irradiation of resins immersed in aqueous media--often swelling occurs up to moderately high doses ( $\left.3-4 \times 10^{8} \mathrm{rad}\right)$, and at still higher doses the resin will shrink. The effect would probably not be of significance for dewatered resins at doses somewhat higher than $10^{8}$ rad, since there would be no source of water for the resins to take up. However, at higher doses, some of the water 
in the resins would presumably be released because of shrinkage, and could be a problem for metal containers if it were corrosive.

Agglomeration has been examined in irradiation studies carried out at BNL(8) with Amberlite IRN-77 in both $\mathrm{H}^{+}$and $\mathrm{Na}^{+}$forms, but only qualitative observations could be made. More recently, BNL(5) has attempted to determine in a quantitative, manner the change in extent of agglomeration with a bsorbed dose. The use of a penetrometer to detect differences in depth of penetration of resin samples recelving different doses did not prove satisfactory due to inability to control other factors which affected the packing. At tempts to correlate absorbed dose with the water pressures required to move the resins when being sluiced, likewise yielded no quantitative measure of the agglomeration effect. With the IRN-77 cation resin,( 8$)$ qualitative observations were as follows: At $10^{8} \mathrm{rad}$, agglomeration was not appreciable. At $3 \times 10^{8}$ rad, a definite stickiness was observed for both the $\mathrm{H}^{+}$and the $\mathrm{Na}^{+}$forms, with the $\mathrm{H}^{+}$form more affected. At $10^{9}$ rad, both forms had a "gummy" appearance. The effect should not be deleterious in itself, but is an indication that damage to the resin has occurred.

Other indications of this kind are the darkening of color with increasing dose and physical breaking of resin beads: The BNL work( 8 ) reported the progressive darkening of the cation exchanger IRN-77, and McFarland $(6)$ did likewise for HCR-S cation resin. Beads of the latter resin are described as slightly darkened at $10^{8}$ rad, and dark black after doses in the range 1 to $5 \times 10^{9} \mathrm{rad}$. Beads of the anion resin SBR-OH were observed to turn slighly brown, but apparently not very dark even at $10^{9}$ rad. Beads of both the anion and the cation resin broke apart physically, as seen by microscopic observation.(6) The extent of breakage increased with increasing dose, and was more serious for the anion than the cation resin. Fracturing was observed with the anion beads at $10^{8} \mathrm{rad}$, but not until $3 \times$ $10^{8} \mathrm{rad}$ for the cation resin.

\subsubsection{Effect on $\mathrm{pH}$ and Container Corrosion}

Ir radiation of a cation exchange resin in the $\mathrm{H}^{+}$form will cause loss of $\mathrm{SO}_{3} \mathrm{H}^{-}$functional groups and formation of $\mathrm{SO}_{2}$ gas. As long as water is present, $\mathrm{H}_{2} \mathrm{SO}_{3}$ will form and dissoclate to give hydrogen, bisulfite and sulfite lons according to the relations governing the respective ionization constants. In an oxidizing medium, a certain amount of sulfuric acid should also be formed. $\because$ In any case, the water present will become more acidic as irradiation proceeds. If the resin is in a salt form rather than the $\mathrm{H}^{+}$form, acid will still be produced on irradiation, but the cation will act like $a$-buffer in that some of it wili be replaced by $\mathrm{H}^{+}$from solution so that the solution will be less acidic than one assoclated with an irradiated resin in the $\mathrm{H}^{+}$form:

These effects have been observed in experimental measurements made at BNL $(8)$ and by Pillay at Penn State. (8) Results of Irradiation at BNL of the nuclear grade cation exchange resin IRN-77 in the $\mathrm{H}^{+}$and $\mathrm{Na}^{+}$forms are presented in Table 3.4 . 
Table 3.4

$\mathrm{pH}$ of Water in Contact With

Irradiated Cation Exchange Resin IRN-77

\begin{tabular}{lrc}
\hline \multicolumn{1}{c}{$\begin{array}{c}\text { Dose } \\
(\mathrm{rad})\end{array}$} & $\mathrm{H}^{+}$Form & $\mathrm{Na}^{+}$Form \\
\cline { 2 - 3 } $10^{7}$ & 3.5 & 6.8 \\
$1.25 \times 10^{7}$ & 2.5 & 4.7 \\
$3 \times 10^{7}$ & 2.5 & \\
$4.6 \times 10^{6}$ & 2.0 & 3.6 \\
$10^{8}$ & 2.0 & \\
$3 \times 10^{8}$ & 1.5 & 2.9 \\
$10^{9}$ & 1.0 & 2.1 \\
& 0.6 & 1.3 \\
\hline
\end{tabular}

Very high acidities were observed for the $\mathrm{H}^{+}$form, and only a little lower for the $\mathrm{Na}^{+}$form, at doses $>10^{8}$ rad. The amount of acid produced by the $\mathrm{H}^{+}$form was essentially linear with dose.

Results for anion resins irradiated by Pillay(7) and McFarland(6) show much smaller changes, although neither of them used the $\mathrm{OH}^{-}$form of the resin. P1llay Irradiated IRA-400 $1 \mathrm{n}$ the $\mathrm{C}_{1}{ }^{-}$form to $4.4 \times 10^{8} \mathrm{rad}$, and found it had the same $\mathrm{pH}(4.6)$ at the end of the irradiation as at the beginning. McFarland with Dow SBR-OH resin in the borate form observed a decrease of about $1 \mathrm{pH}$ unit at around $\mathrm{pH} 8$, on going from $10^{8} \mathrm{rad}$ to $10^{9} \mathrm{rad}$.

Because of possible undesirable results from corrosion damage to metal containers of highly loaded resins, a considerable effort has been put into corrosion studies at BNL, $(5,8)$ by Pillay $(7)$ at Penn State, and by Marek and Rinker $(6)$ at Georgia Institute of Technology. The general method used was to irradiate resins to various doses in contact with metal specimens, particularly mild and stainless steels, then examine the specimens, determine welght loss, etc. All three groups worked with cation resins; Pillay and Marek and Rinker also used anion resins. With the cation resins, appreclable corrosion of stalnless steels was observed only at doses much $>10^{8}$ rad, whereas mild steel was affected more severely. The effects parallelled the $\mathrm{pH}$ changes observed on Irradiation of the resin, as would be expected. Pillay found a certain amount of corrosion of mild steel with his anion resin, presumably at least partly because it was in the $\mathrm{C1}$ - form with a $\mathrm{pH}$ of 4.6 . Marek and Rinker found no sign of corrosion on any stainless steel samples, even at the highest dose of $10^{9} \mathrm{rad}$, again presumably partly because of $\mathrm{pH}$, but this time a $\mathrm{pH}>7$. 


\subsubsection{Nuclear Grade Resins}

Most of the work reviewed by Gangwer et a1.(6) was done with ordinary commercially available resins, whereas the BNL work and McFarland's study described in the last section (3.2.4) used nuclear grade resins. The latter were used because of the wish to keep experimental conditions as close to plant conditions as possible, and nuclear grade resins appear to be used by most, if not all, nuclear power plants (see Section 2.1.1). The question then arises as to how comparable are experimental results obtained with these different grades of resins.

We have been unable to find published information on comparison of radiation effects in nuclear and non-nuclear grades of the same resin. However, a good indication of how comparable they will be should be gained by considering the known differences between them. These differences, which are not large in any case, are found mainly in the levels of impurities and the uniformity of bead size. Nuclear grade resins are typically limited to $0.5 \%$ fines smaller than 50 mesh and a simflarly low percentage greater than 16 mesh. After the polymerization step in the manufacturing process, the material is treated to remove water-soluble organic compounds to a very low level. Inorganic impurities are kept $10 \mathrm{w}$ by special treatment during the manufacturing process. For Amberlite resins, these levels are: $<200 \mathrm{ppm}$ iron, $<100 \mathrm{ppm}$ copper, and $<100$ ppm heavy metals.

These particular specifications are almed at achleving good operating parameters (e.g., low pressure drop) and maintalning the quality of the water in the liquid streams which have to be processed at nuclear plants. The most important consideration is to minimize corrosion of the reactor and turbine systems and radiation resistance would only be a consideration at all if, for some reason, it turned out to be poor for nuclear grade materials. Apparent$1 y$, it has been assumed that there should be little difference between nuclear and non-nuclear grades of the same resin, and there seems to be no evidence to doube that assumption.

Nuclear grade resins under irradiation would perhaps give slightly smaller amounts of gas and other decomposition products due to their smaller contents of soluble organic impurities. However, the organic impurity contents are quite low for both grades, so the effect could not be large. In any case, small (and therefore soluble) organic molecules are produced in both grades of resin by the action of radiation. As regards the inorganic impurities, in cation resins the salt forms with iron and copper as the bound cations have been empirically found to be much more stable to radiation than the $\mathrm{H}^{+}$form. (4) The reason for this was not given. In any event, the nuclear grade with its lower iron and copper Impurities would probably be slightly less stable. However, again the difference would be very slight because the impurity levels are low in both grades. On balance, then, it appears that there should be very little difference between nuclear and non-nuclear grades of the same resin in terms of their resistance to radiation.. 


\subsection{Cholce of a Maximum Loading Limit}

\subsubsection{Basic Considerations}

NRC has taken the position (In a draft BTP of October 30, 1981) that resins for disposal should not undergo degradation. Extensive degradation of organic ion exchange media would most certainly complicate the ef fective management of these wastes, as described above. However, we consider it fair to permit a small amount of degradation or damage if such damage wil1 pose no problem to the burial site or the general environment.

Any dose of radiation will cause some damage to an ion exchange resin. Very small amounts of damage will be undetectable and obviously of no significance from a regulatory point of view. What is required is identification of a degree of damage which has a high probability of causing small but significant deterioration in performance and/or significant risk to the public health and safety. Radiation damage is always measured in terms of the dose received by the material damaged. Thus, in this section, the question is considered of what dose resins should be permitted to receive in order not to exceed the degree of damage described above. The question of whether to couch the Branch Technical Position in terms of a curie loading ( $\mathrm{Ci} / \mathrm{ft}^{3}$ of resin) or a dose delivered to the resin is discussed in a later section (3.4).

We have taken the position (Section 3.2.5) that there is 1ittle difference in radiation stabllity between nuclear and non-nuclear grades of the same resin type. Accordingly, information from the literature on non-nuclear grade resins will be used along with more recent results of work on muclear grade resins in order to arrive at a position on a maximum allowable dose to power plant resins for disposal (which will probably be only nuclear grade).

Another point which must be kept in mind is that the resins of most concern, $1 . e .$, those used for reactor coolant cleanup and which thus accumulate the highest RN loadings, are most likely to be mixed cation and anion, in the $\mathrm{H}^{+}$and $\mathrm{OH}^{-}$forms. They may be mixed by the user, or purchased as mixed bed resin. The usual mixture at the plants responding to our questionnaire was a $1: 1$ ratio and this will be taken as the standard. The only types of resins constdered are the strong base anion and strong acid cation polymerization types.

A final requirement for use of information from the literature is that this information pertain to resing with a similar water content to those disposed of by power plants. The latter are referred to as dewatered, and should have almost no free water in the container when shlpped. A corresponding condition for resins used in the experimental work reviewed by Gangwer et al.(4) is termed "molst" or "swollen." Data obtained with dry resins and resins immersed in water cannot be considered acceptable for present purposes.

\subsubsection{Minimum Deleterious Changes in Properties}

We feel that it may be reasonable to permit a small degree of damage to resins for disposal; for example, the amount that would be caused by the dose 
at which damage could just be positively identified. However, at that dose some other property might be degraded. to a greater extent, perhaps too great to be considered permissible. Thus, the dose limit may have to be determined by the effect on the property most sensitive to radiation damage. Whether or not this will, be necessary will depend on whether the deterioration in that property is capable of causing significant increased risk to the public, including operators at disposal sites. In this section the different properties affected by radiation are considered in the above context.

\subsubsection{Gas Generation}

The differences between McFarland's gas ylelds and those found in the earlier literature have been discussed (Section 3.2.4.1). The G-values calculated from McFarland's data at $7.9 \times 10^{8}$ rad were 0.09 and 0.69 for cation and anion exchanger, respectively. These values are 0.04 and 0.28 when calculated at $10^{8}$ rad, which are somewhat lower than previous literature values. Since McFarland irradiated his resins in a dewatered state, using a dewatering procedure similar to that used in power plants, and since his experimental gas handing and measuring equipment was expressly designed for these experiments, we feel that his results must be given great welght. However, the conservative position requires consideration of the data indicating the greatest damage if the experimental work cannot be faulted. Thus, we have averaged the results from McFarland's experiments with the higher values of Mohorcic(16) on cation resin and Kazan jlan(15) on anion. resin, as given in Section 3.2.3, for purposes of calculating gas formation from representative power plant resin at two representative doses. McFarland's experimental data as given in Table 3.3 and the plots of Figure 3.2 a re used in this calculation.

At a dose of $10^{8} \mathrm{rad}$, McFarland's total gas production for a $1: 1$ cation: anton mixture amounts to $1.6 \times 10^{-5}$ moles/g of resin, while at a dose of $2 \times 10^{8} \mathrm{rad}$ it is $5.4 \times 10^{-5}$ moles/g of resin. This does not include any correction for difference between $\mathrm{H}^{+}$and $\mathrm{Na}^{+}$form, since Mohorctc did not observe an appreciable difference between the $\mathrm{H}^{+}$and $\mathrm{Li}^{+}$ forms of Dowex 50W for moist resin. Nor is it possible to apply a correction to the results for anion exchanger since there is no information on 1rradiation of borate form versus $\mathrm{OH}^{-}$form. Kazan flan's result of $8.9 \times 10^{-6}$ moles/g for Dowex-1, calculated from G-values given in Table 3.2, must be adfusted upward to account for the difference between molst and dry resin, and to convert from $\mathrm{H}_{2}$ production to total gas production. For the latter, a factor of 1.8 is used, besed on McFarland's. results, and for the former, a factor of 2 is judged reasonable bed on comparison with McFarland's results for molst anion resin. Mohorclc!s result (Figure 3.1 ) has to be ad justed on ly for the difference between total gas and $\mathrm{H}_{2}$ production, which is taken as a factor of 2.4 on the basis of McFarland's results. Kazan flan's result for anton resin $1 \mathrm{~s} .3 .6 \times 10^{-5}$ moles/g of resin, and Mohorcic's value for cation resin is $2.2 \times 10^{-5}$ moles/g of resin. Thus, for a $1: 1$ cation anion mixture, the value taken is $2.9 \times 1.0^{-5}$ moles $/ \mathrm{g}$. The average of this result with that of McFarland is $2.2 \times 10^{-5}$ moles/g of resin at $10^{8}$ rad. For $2 x$ $10^{8} \mathrm{rad}$, the value for Mohorclc and Kazanjlan is assumed to double to $5.8 \mathrm{x}$ $10^{-5} \mathrm{moles} / \mathrm{g}$ of resin on the basis of the linear increase of yield with dose 
obtained by Mohorcic. The average of this value with McFarland's then becomes $5.6 \times 10^{-5} \mathrm{moles} / \mathrm{g}$ of resin for a dose of $2 \times 10^{8} \mathrm{rad}$.

Assuming a sealed container, filled with dewatered resin to $90 \%$ of capacity, a resin density of $1 \mathrm{~g} / \mathrm{mL}$ and a void volume of $50 \%$ in the resin, approximately 1.05 atmosphere of excess pressure would build up at $2 \times 10^{8} \mathrm{rad}$ based on the above average total gas yield value. In other words, the volume of additional gas produced would be somewhat greater than the void volume of the filled container. At $10^{8}$ rad the excess pressure build up would be 0.43 atmosphere. Although 1.05 atmosphere excess pressure would probably not damage the container, whether steel liner or high integrity polyethylene, the lower value would be preferable from the point of view of conservatism. Also, since gas pressure from bacterlal degradation may build up in a sealed container, as reported by the Duane Arnold power plant (Section 2.1.5), it is particularly important not to generate appreciable amounts of gas by any other means. This leads to the cholce of $10^{8} \mathrm{rad}$ as the dose to be permitted for maximum loading based on gas generation.

\subsubsection{Changes in Appearance}

As pointed out in Section 3.2.4.2, the changes in appearance (swe11ing, darkening, agglomeration, and fracturing of resin beads) do not in themselves constitute effects which will produce a dangerous situation, but indicate that the resins have been altered, and have therefore undergone radiation damage. Resin shrinkage, occurring at doses much greater than $10^{8}$ rad; could release water and therefore should be avoided. Other changes in appearance become noticeable in the vicinity of $10^{8}$ rad. Fracturing of anion resin beads was observed by McFarland at $10^{8}$ rad but cation resin beads did not show the effect until $3 \times 10^{8} \mathrm{rad}$. Since our reference resin is a $1: 1$ cation/anion mixture (Section 3.3.1), the lower dose must be chosen. It can be concluded then that the radiation damage indicated by these appearance changes is small, but definite at $10^{8}$ rad. Therefore $10^{8}$ rad is the maximum permissible dose indicated by these effects.

\subsubsection{Exchange Capacity}

This property is relatively sensitive to radiation. For resins irradiated to $10^{8}$ rad under the molsture conditions of dewatered spent resin, los s of exchange capacity is reported (Section 3.2.2) as 5-10\% for cation exchangers and double that amount for anion exchangers. Quantitative data are not available for relevant resins at doses much below this, but it seems clear that detectable loss of exchange capacity would occur at half the dose, or $5 \mathrm{x}$ $10^{7} \mathrm{rad}$, and probably even lower. However, los of exchange capactity in itself does not consistitute a hazard to personnel or cause damage to containers. The resin damage it represents is removal of the functional groups, a process which does not damage the structural framework of the resin. Thus, it is felt that it is not appropriate to use it as the basis for establishing a limiting radiation dose. 


\subsubsection{4 pH and Corrosion}

$\mathrm{pH}$ changes in cation resins in both the $\mathrm{H}^{+}$and salt forms are observed at quite low doses $-10^{7}$ rad or less (Table 3.4 ). They are linked closely to loss from the resin of $\mathrm{SO}_{3} \mathrm{H}^{-}$functional groups. Anton resins in the salt form on the other hand, have shown only small changes at doses up to $10^{9} \mathrm{rad}$. It would be expected that anton resins in the $\mathrm{OH}^{-}$form would show greater changes, with an increase in basicity, due to generation of $\mathrm{NH}_{3}$ and amines. We have found no information on irradiation of mixed cation and anion resins, but changes in $\mathrm{pH}$ of the mixtures could be much less than those seen for cation resins alone, due to takeup of $\mathrm{SO}_{3} \mathrm{H}^{-}$by the anion resin and neutralization of acid by released $\mathrm{OH}^{-}$.

It appears that predicting damage to mixed resins by $\mathrm{pH}$ change on irradiation would be very uncertain, in that very large doses might show little or no $\mathrm{pH}$ change. This in itself is enough to negate its usefulness as a basis for setting a dose limit for resins. In addition, even if prediction were reasonably certain, the type of damage measured by $\mathrm{pH}$ change is largely loss of functional groups, and not damage to the structural framework of the resin. Finally, current experience at nuclear power plants indicates a wide range of $\mathrm{pH}$ values (2-9) is to be expected in undamaged spent resin. Thus, as with exchange capacity, we feel that $\mathrm{pH}$ change would not be appropriate as a basis for establishing a maximum permissible dose. These foregoing reasons also apply to corrosion effects, since corrosion is directly linked to pH.

\subsubsection{Dose Rate Effects}

The greatest difference between the experiments from which our radiation damage Information has been obtained and the actual long term irradiation of spent power plant resins lies in the different dose rates in the two types of situations. A typical dose rate in the experimental work is $10^{6} \mathrm{rad} / \mathrm{h}$; it can vary from somewhat lower to $10^{7} \mathrm{rad} / \mathrm{h}$ or higher. The spent resin, on the other hand, 18 subjected to a dose rate several orders of magnitude less. For example, resin loaded with Co-60 ( 5.3 yr half-1ife) in an amount which would deliver a total dose of $10^{8}$ rad would be irradiated at considerably less than $10^{3} \mathrm{rad} / \mathrm{h}$. For the same total dose and $\mathrm{Cs}_{-137}$ as the source, because of the latter's 30 year half-1ife, the dose rate would be little more than $100 \mathrm{rad} / \mathrm{h}$.

The differences in radiation effects which might result from such large differences in dose rate are not known. Recent work at Sandia(20) has shown that radiation at low dose rates $\left(10^{3}-10^{4} \mathrm{rad} / \mathrm{h}\right)$ can cause much more damage to polyethylene and polyvinyl chloride than the same total dose at the dose rates normally used in accelerated tests $\left(10^{6}-10^{7} \mathrm{rad} / \mathrm{h}\right)$. The mechanism proposed (20) involves perioxide formation and subsequent thermal decomposition, and it is not clear that such a mechanism would be operative with the largely aromatic structures of fon exchange resins. However in light of this work on aliphatic polymers, there remalns the caveat that an increase in damage to lon exchange resins might result from the low dose rates encountered in practice. There is evidence (e.g., Swyler et al.(8)) that dose 
rate variations of a factor of 10 have no effect on $\mathrm{pH}$ changes due to 1rradiation. However, the dose rates used are so much higher than those occurring with spent resins that no extrapolation can be made to the latter:

Intuitively, one could argue that in the spent resin situation, damage. is done so slowly that some of $1 \mathrm{t}$ will have an opportunity to be repalred (e.g., long-lived radicals may be able to recombine). This would obviously not apply to processes 11 ke $\mathrm{H}_{2}$ formation, where the intermediate $\mathrm{H}$ radical ( $H$ atom) is very reactive and short-lived. Gas buildup in a container, hydrogen buildup particularly, could however, be influenced by the long time frame dictated by a low dose rate. Over a period of many years, as gas pressure built up, unless the metal container were perfectly sealed, or if the container were plastic, the gas would gradually escape through small leaks or by diffusion through the plastic. This would constitute a mitigating effect in the case of a limiting dose to be set on the basis of gas generation. There is some mitigating influence in other damage effects as well (such as that causing container corrosion), because of the long time over which the radiation damage products which cause or enhance the effect are formed.

\subsubsection{Selection of the Maximum Dose}

A rationale for the choice of aximum allowable dose to spent resins from nuclear power plants has been given in Section 3.3.1. In Section 3.3.2 the doses associated with the different effects caused by radiation were examined, and the doses identified at which smali but detectable degrees of damage resulted. On the basis of all the information reviewed regarding the experimentally observed effects of radiation on resins of the same types as those used at nuclear power plants, in view of possible mitigating factors such as the very low dose rates involved in long-term irradiation, and taking into account the uncertainties involved in determining actual resin loadings at the plants, a maximum dose which power plant resins should receive is considered to be $10^{8} \mathrm{rad}$.

It may be felt that a maximum permissible dose of $10^{8}$ rad is too conservative, and indeed, because of uncertainties in measuring, some of the radiation effects, a reasonable case can probably be made for setting the limit at some higher value, such as $2 \times 10^{8}$ rad. However, it should be noted that, in practice, determination of the RN loadings of large batches of used power plant resins is rather imprecise due to problems in obtaining representative samples. Thus, dose calculations based on such samples will also be 1mprecise. It is not inconcelvable that a calculated dose might be a factor of 2 greater or less than that which the resin would actually receive, so that in an extreme case a batch might receive $2 \times 10^{8}$ rad when inaccurate analysis Indicated it should receive only the limiting dose of $10^{8}$ rad. It is con-... sidered that an adequate margin of safety would exist for resins inadvertentiy loaded so as to recelve a total dose of $2 \times 10^{8}$ rad. It seems clear, however, that a $10^{8}$ rad regulatory limit is not too conservative in view of the inherent imprectsion in determining resin loadings encountered in actual plant experience. 


\subsection{Regulatory Use of Delivered Dose}

\subsubsection{Technical Basis}

We feel that NRC's branch technical position (BTP) should be stated in terms of a delivered dose rather than a curfe loading. It is technically imprecise to relate extent of damage to curle loading, since, for a given curie loading, different RNs (or different mixtures of RNs) can cause widely different degrees of damage. Our power plant survey showed that the RNs on resins for disposal vary from largely activation products to largely fission products. Co-60 is the controlling $\mathrm{RN}$ for activation products, and $\mathrm{Cs}-137$ for fission products. For a uniform loading of $10 \mathrm{Ci} / \mathrm{ft}^{3}$, the total dose delivered by Co-60 to a typical $100 \mathrm{ft}^{3}$ batch of resin would be approximately $6.4 \times 10^{7}$ rad depending on the exact shape of the resin container. For the same uniform loading of $\mathrm{Cs}-137$ on a bed of the same geometry, the dose delivered would be $1.3 \times 10^{8} \mathrm{rad}$. The $\mathrm{Sr}, \mathrm{Y}-90$ couple does not appear to contribute much to the total activity in power plant wastes, but it should be noted that, at a loading of $10 \mathrm{Ci} / \mathrm{ft}^{3}$, a total dose of $2.6 \times 10^{8}$ rad would be expected.

\subsubsection{Calculation of Total Dose}

Use of a curie level to assign a value for maximum loading might be permissible if calculation of total dose from a given loading of RNs was extremely difficult or: subject to large error. However, neither is the case. Swyler, Barletta, and Davis(8) describe a method of calculating the dose, either at any time after loading or after total decay, from $\beta, \gamma$-emitting RNs. A full development of the equations is given in the appendix to their report. (8) For deposition of $\beta$-energy, the calculation can be made essentially exact, since the $\beta$-particle range is so short that $>99 \%$ of the total $\beta$-energy is absorbed in the resin bed and the average $\beta$-energies are accurately known for the isotopes involved. For $\gamma$-energy deposition, estimation of the absorption of the $\gamma$-rays in the resin-water system is required. Values of the gamma ray constant, $\Gamma$, are given for a number of common RNs associated with the nuclear fuel cycle in the "Radiological Health Handbook."(21) Assuming tissue equivalency for the resin-water system, Swyler et al. (8) calculated the geometry factor, $\bar{g}$, given by Hine and Browneli(22) as a function of bed geometry. Estimation of $\bar{g}$ involves the greatest uncertainty in the $\gamma$-dose calculation, but it is well within the limits that would be required for normal reporting of loadings to burial sites.

The calculations are not difficult and could be done routinely by the generator. Indications from the survey are that some generators use calculations based on radiation field (similar to dose rate) to determine their resin loadings. Such calculations have similar requirements and assumptions to those involved in the calculation of Swyler et al. A computer program based on the latter. has been written and is given in Appendix E. 


\subsubsection{Sr-90 Reporting Requirements}

The results of our power plant survey indicated that rather small amounts of Sr-90 are present in their resin wastes. Only 3 plants reported it in their list of principal RNs on dewatered resin and only two gave a value for its level on spent resin. One of the latter plants routinely used a value of $1 \%$ of the Cs-137 level, since periodic analyses had never given a higher result. The other plant sent a recent analysis showing the sr-90 content of the resin as $2.5 \%$ that of $\mathrm{Cs}-137$. Based on these results and on phone calls to several other plants, it appears that $\mathrm{Sr}-90$ levels in the liquid streams. and on the spent resins are in general much lower than Cs-137 levels. In such cases, it would therefore not need to be considered for calculating long-term dose to the resins, particularly if activation products constitute the bulk of the activity disposed of. However, due to the high dose from the Sr,Y-90 couple compared with that from the other major contributors, (twice that of Cs-137 and four times that of Co-60 for large volumes of resin--see Section 3.4.1) we feel it is prudent to require that generators report $\mathrm{sr}-90$ levels on their coolant cleanup resins to disposal sites. Further, they should explicitly include Sr,Y-90 contribution in their total dose calculation.

\subsection{Recommendations for Additional Research*}

It has been pointed out(4) that there is a certain lack of agreement, as well as a lack of quantitative data, in the published literature on radiation effects in organic ion exchange resins. This is particularly true for anion resins. In attempting to arrive at a quantitative value for maximum permissible dose to resins being disposed of by nuclear power plants, we had to make several extrapolations from one form of resin to another (e.g., $\mathrm{Li}^{+}$ form to $\mathrm{H}^{+}$form), and from dry to moist resin, because the required data were not available. In order to avoid uncertainties of this kind, a satisfactory data base should be developed, particularly for resins of the types used in power plants. The following recommendations for additional research, if implemented, would provide much of the information needed. It should be noted that moisture content is critical to the results obtained. Thus, in all the experimental work suggested below, the water content of the resin samples must be accurately known.

- To permit use of information from earlier literature obtained with non-nuclear grade resins, a check should be made comparing samples of nuclear grade and non-nuclear grade of the same resin, both anion and cation. Properties to be used for comparison are gas generation (preferably individual gases), changes of $\mathrm{pH}$, and loss of exchange

*Since this report was published in draft form (BNL-NUREG-30668, January 1982 ) experimental work has been performed at BNL in most of the areas suggested. Results are given in the quarterly progress reports, "Characterization of TMI-Type Wastes and Solid Products," BNL-NUREG-51499, April 1982, BNL-NUREG-31413, June 1982, and BNL-NUREG-31568, July 1982. 
capacity. Dewatered resins should be used, at least in the $\mathrm{H}^{+}$and $\mathrm{OH}^{-}$forms and absorbed doses should be adequately distributed over the range $10^{7} \mathrm{rad}$ to at least 2 to $3 \times 10^{8} \mathrm{rad}$.

- Continuing from this point with nuclear grade resins only, the same properties should be determined for salt forms, such as lithlated and borated, which are used in power plants. Both dry resins and dewatered resins should be tested, in both the salt forms and the $\mathrm{H}^{+}$ and $\mathrm{OH}^{-}$forms.

- There is almost no information on irradiation of mixed anion and cation resins. This situation should be remedied in order to provide data relating to the conditions in actual plant use. Irradiations should be carried out, over the same dose range as before, on samples of $1: 1$ anion: cation resin mixtures in the $\mathrm{H}^{+} / \mathrm{OH}^{-}$form and in both the dry and dewatered state. The dewatered samples should be tested for $\mathrm{pH}$ change in particular. It is thought that gas generation from mixed resins should be the sum of the amounts generated from the cation and anion resin irradiated separately, and this point should be checked.

\subsection{Dose From Short-Lived RNs During Plant Operation}

\subsubsection{Potential for Damage}

The possibility that decay of the short-lived RNs on resins in demineralizer systems during reactor operation could deliver a significant dose to the resins was pointed out in Section 2.2. In that section, analytical results provided by several power plants for their reactor coolant were given (Tables 2.4-2.8) along with data on gross $B$, $\gamma$-activity in the feed to the coolant cleanup demineralizers (Table 2.2 ).

The analyses indicate that reactor coolant routinely contains relatively high activity levels of short-1ived RNs (several days or less) and low levels of the longer-lived isotopes (such as Co-60 and Cs-137, with halflives, respectively of 5.3 and 30 years) which make up the bulk of the activity on spent resin for disposal. The high overall DFs reported for gross $\beta, \gamma-$ activity across the beds [which agree with those given by Lin(1)] show that while the beds are in service, they are continually receiving an appreciable radiation dose from the short-lived nuclides, since the activity loadings are of the order of $1 \mathrm{mCl} / \mathrm{ml}$ of $\operatorname{resin}\left(28 \mathrm{Ci} / \mathrm{ft}^{3}\right)$.

\subsubsection{Dose Determinations and Relevance to a Maximum Loading Rule}

In order to determine whether such a dose would contribute importantly to the overall dose eventually recelved by the resin, calculation of its magnitude at Dresden Unit 2 was carried out, based on the extensive analytical data and information on plant operation supplied in their response to the questionnaire and by subsequent telephone contact. Of the RNs they monitor 
(see Table 2.4), those that deliver the bulk of the short-term dose are $\mathrm{I}-131,132,133,134,135, \mathrm{Ba}, \mathrm{La}-140, \mathrm{Cs}-138, \mathrm{Na}-24, \mathrm{Fe}-59, \mathrm{Zr}-95, \mathrm{Ba}-139, \mathrm{Tc}-104$, and $\mathrm{Ce}-141$. Their mean lives range from less than an hour to 3 months.

Since in 5 mean lives an isotope will bulld up to within $1 \%$ of its saturation level on a fresh bed, those isotopes with mean lives of 20 days or less w111 reach their saturation levels in 4 months or less. From thè time they reach saturation, their rates of decay are equal to their rates of bulldup on the resin, assuming constant coolant flow rate through the bed and constant reactor power. Thus, they deliver a continuous dose to the resin all the time the bed is in service. After the bed is removed from service and the RNs decay, the dose from their decay will exactly compensate for the deficit in dose during bulldup, before saturation is reached. Hence, the total dose delivered by the short-lived isotopes is simply the dose rate at saturation multiplied by the time the bed is in service.

For isotopes of slightly longer mean life $(\tau)$ which do not quite reach saturation in 6 months, the dose delivered by decay after removal of the bed from service will not be quite enough to compensate for the difference between actual and saturation levels during buildup. However, for an isotope of mean Iife 90 days ( 6 months $\approx 2 \bar{\tau}$ ) the error involved in assuming complete compensation is only about $1 \%$. Thus, $\mathrm{Zr}-95$ ( $\tau=94$ days) and Co-58 ( $\tau=102$ days) can be included in the calculations with introduction of an insignificant error in the total dose from all short-lived isotopes.

In Appendix F, calculations are given for the $\beta$-dose from $\mathrm{Ba}-140$ using the above treatment and a treatment based on the method of Swyler et al. (8) described in section 3.4.2, which gives the same result. This second treatment is used to determine the $\gamma$-dose from $B a-140$. The sum of the $\beta-$ and $\gamma-$ doses from $\mathrm{Ba}-140$ is calculated as $1.3 \times 10^{6}$ rad. Applying the same methods to the other short-1ived isotopes listed above leads to a total delivered dose of $6.4 \times 10^{6} \mathrm{rad}$ in 6 . months of operation (plus subsequent decay time).

This calculated dose is an underestimate for several reasons. There are a number of fission product isotopes of high fission yield (e.g., Rb-88,89, $\mathrm{Y}-92,93,94, \mathrm{Ba}-142, \mathrm{Te}-133,134)$ which w11l probably also be present but which are not measured by the analytical methods employed by this particular plant. Also, in the calculation dose is assumed to be equally distributed between water and resin in the bed. This is a good approximation for $\gamma$-dose, but $\beta$-dose will be greater to the resin. A realistic estimate of the total dose delivered at Dresden by all short-lived isotopes is most likely $\left\langle 10^{7} \mathrm{rad}\right.$. The Dresden situation is probably average, since the fission product activity in the coolant comes from uranlum "plated out" on core surfaces rather than from fuel element leaks. Some plants have lower activities in the coolant and/or change beds* more frequently so that their resins receive a lower dose. Other plants operate from time to time with slight fuel leaks, so that

\footnotetext{
*.Bed" as used here includes powdered demineralizers.
} 
fission product concentrations in the coolant could be higher, but their coolant cleanup beds* may have much shorter service times than Dresden's, and thus radiation dose to the resin during bed operation probably will be comparable to Dresden's or $<10^{7} \mathrm{rad}$.

We conclude that $1 \mathrm{t}$ is unlikely for any power plants to produce waste resins recelving a dose from short-lived isotopes much $>10^{7} \mathrm{rad}$, or $10 \%$ of the $10^{8}$ rad suggested as the maximum permissible limit. Dose from this source, therefore, would normally contribute an amount which would be within the limits of error for. estimating a dose of the order of $10^{8} \mathrm{rad}$. The significance of this:"extra" dose, however, is that it supports a conservative position for setting a maximum permissible dose from long-lived RNs, since an appreclable uncertain contribution to total dose will always occur from short-lived RNs, and perhaps from other sources of radiation we have not considered.

\subsection{Solidified Resins}

It is beyond the scope of this report to consider dose limits for solidified resins. However, it is appropriate to draw attention to recent studies of radiation damage to cement-resin composites which indicate a high degree of stability for certain solidified resin forms. (5) In view of such results, a dose limit of the order of $10^{9}$ rad to the resin might be considered for sultable solidified forms which could lead to significant waste volume reduction of benefit to both the generator and the disposal site. The results of these experiments and recommendations for additional research in this area are discussed below.

\subsubsection{Experimental Results of Radiation Damage Studies}

The manner in which p operties of EPICOR-II type Ion exchange media changed with radiation exposure has recently been investigated. (5) The material studied was a proprietary mixture called D-mix, consisting mainly of organic resins and claimed by the vendor to be representative of the Epicor-II first-stage if ner material. Irradiations of $\mathrm{D}$-mix alone were carried out to determine its effect on gas generation, agglomeration, $\mathrm{pH}$, and corrosion of potential container materials. A number of irradiations of. D-mix solidified with cement were also carried out, and the results of the testing done on these composites as they relate to the matter of a maximum permissible loading, are summarized below.:

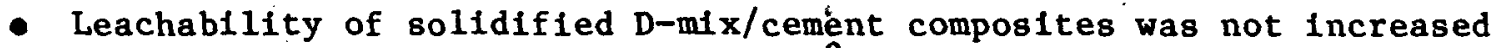
by irradiation to a total dose of $10^{9} \mathrm{rad}$.

- No deleterfous effects to the mechanical integrity of the composites were observed, as measured by tensile splitting strength.

\footnotetext{
*"Bed" as used here includes powdered demineralizers.
} 
- There was no measurable corrosion of stainless steel either with $D-m i x$ alone or with composites at any dose.

- No unambiguous evidence of radiation enhancement of mild steel corrosion was found for samples in contact with $\mathrm{D}-\mathrm{mix} /$ cement composites at a total dose of $10^{9} \mathrm{rad}$. This is in contrast to the enhanced corrosion observed with $\mathrm{D}-\mathrm{mix}$ alone, which was noticeable at $10^{8} \mathrm{rad}$.

- The major gas produced as a result of irradiation of the composites was hydrogen. Very little $\mathrm{CO}_{2}$ or methane were formed in the composites, whereas appreciable quantities were generated in D-mix alone.

- As described in Section 3.2.4.1, with both D-mix alone and D-mix/ cement composites, a marked decrease in oxygen content of the atmosphere in sealed containers upon irradiation was observed (nearly complete depletion in the case of the composites).

\subsubsection{Conclusions Regarding Maximum Loading}

From the results given above, it can be concluded that mechanical integrity and leachability of the $\mathrm{D}-\mathrm{mix} /$ cement composites are not affected by irradiation to a total dose of $10^{9} \mathrm{rad}$. There may be a slight enhancement of corrosion of mild steel at the higher doses, but this is not definite. Thus, from the point of view of these properties, the composite waste form could be used for incorporation of $D$-mix which would deliver such doses. Gases such as $\mathrm{CO}_{2}$ and light hydrocarbons are formed in only small amounts, suggesting that degradation of the organic resins present in $D$-mix may be less extensive upon solidification with cement. However, gas generation (mostly hydrogen) is still appreciable from the composites. Based on all these results with the single material, D-mix, it appears that solidifying resins with cement would permit a loading which would give a dose to the resin, if not solidified, of considerably higher than $10^{8} \mathrm{rad}$, and perhaps as high as $10^{9}$ rad. A similar conclusion is reached for resins solidified in Dow Chemical Company's vinyl ester-styrene polymer according to a study by Dow using both BWR and PWR resin wastes. (23) However, insufficlent data are presently avallable on which to base a recommendation to permit higher doses such as $10^{9}$ rad to composites, and in the next section suggestions are given for experiments which could generate the required data. 


\subsubsection{Recommendations for Additional Research*}

The principal requirements to be met by additional research are to generate results with material that is not proprietary, and to broaden the information base with respect to both resins and solidification agents. Some specific suggestions are:

- Cement composites should be prepared and tested using commercially available, non-proprietary, anion and cation exchangers, individually and in a 1:1 mixture. Nuclear grade resins should be used.

- The unsolidified resins should be tested at least for gas generation, to provide a reference point for comparison with the composites.

- A range of solidification agents consistent with those currently in use at nuclear power plants should be tested. An organic material such as Dow vinyl ester-styrene polymer should be compared with inorganic solidification agents such as cement and cement-silicate mixtures.

- The resin/waste composites should be tested at least for gas generation, changes in leachability, and mechanical stability, to total doses of $10^{9}$ rad. Leachability and mechanical stability tests used should be those described in the draft Branch Technical Position.

\footnotetext{
*Since this report was published in draft form (BNL-NUREG-30668, January 1982), experimental work has been initlated at BNL in the first area recommended, and work in additional areas 18 planned. Preliminary results are given in the quarterly progress report, "Characterization of TMI-Type Wastes and Solid Product8," BNL-NUREG-31568, July 1982.
}

$$
43 / 44
$$




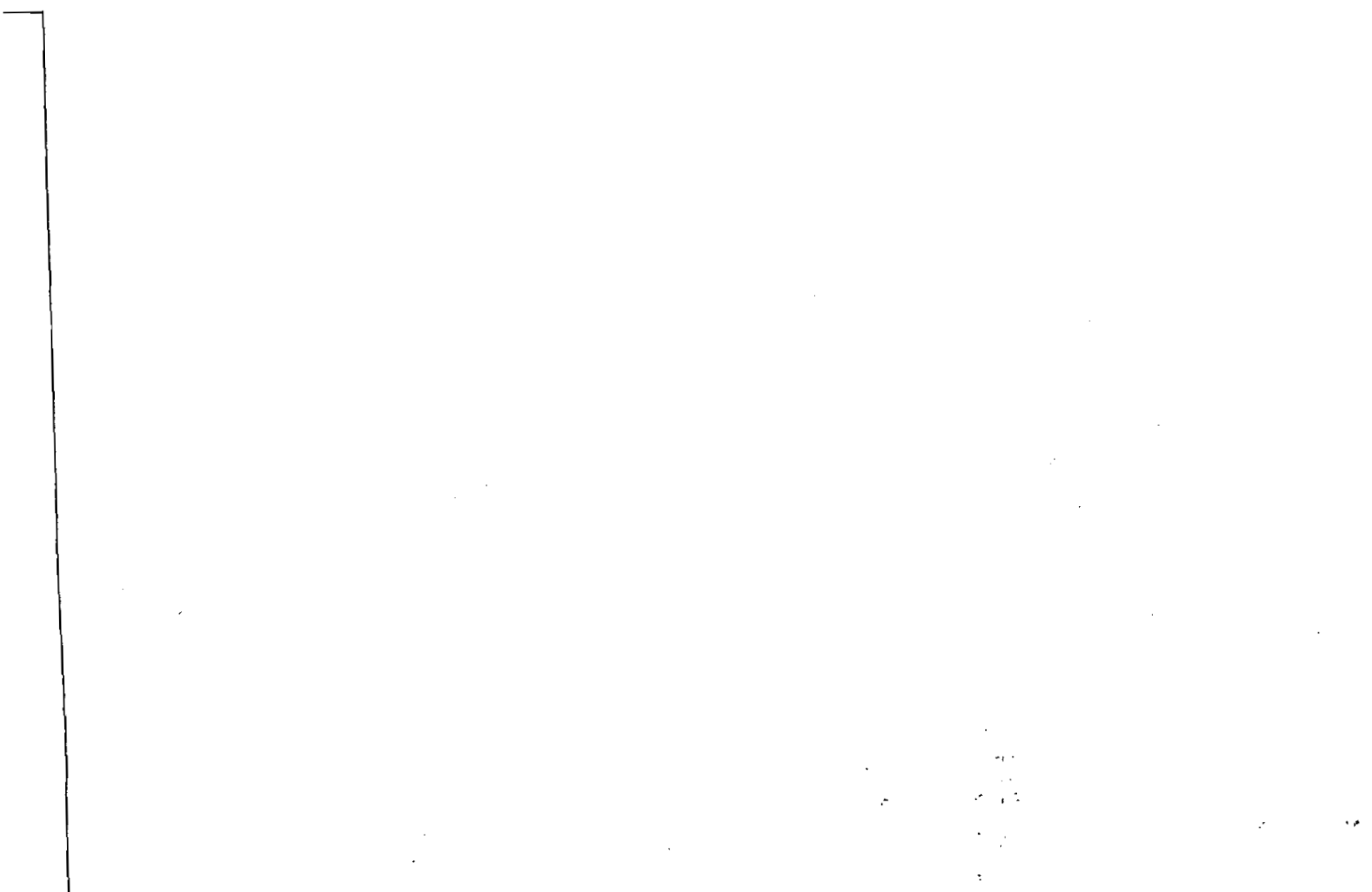




\section{TEST FOR PERMITTING EXCEPTIONS TO THE GENERIC RULE}

There is a possibility that a generator may wish to use a resin, or resin mixture, which it claims can be loaded to a level higher than that allowed by the BTP, without resulting in degradation. Examples exist of resins which have considerably greater radiation stability than those presently in general use, particularly the anion resins with pyridine units in their structural framework. NRC's draft BTP requires that a generator wishing to load a resin to some higher level than permitted by the rule must demonstrate that the resin will not undergo degradation at that loading level.

In developing a suitable test to provide this demonstration, several conditions should be met:

1. The test method should adequately simulate the chemical and radiological conditions which would be encountered in actual practice.

2. The test should be reasonably simple and consistent with the types of operation and experimental equipment required to obtain accurate results. Simplicity, however, cannot be considered a limiting factor, since this would be a "one time only" test, and not a routine procedure.

\subsection{Adequate Simulation of Conditions Expected in Practice}

\subsubsection{Use of Chemical Solutions}

It has been argued that the effects of radiation on resins, either in water or containing water, can be produced by treating them with chemical solutions, particularly solutions of $\mathrm{H}_{2} \mathrm{O}_{2}$. It is undoubtedly falr to say that some of the effects of radiation will be produced by such solutions, since $\overline{\mathrm{H}_{2} \mathrm{O}_{2}}$ is inevitably formed by radiolysis of water. However, it would be a gross oversimplification to contend that this or any other chemical can adequately simulate exposure to radiation at the doses required in a test.

In the first place, $\mathrm{H}_{2} \mathrm{O}_{2}$ cannot cause ionization. Aside from this obvious difference, in fact because of $1 \mathrm{t}$, a large chemical discrepancy also exists. Ionizing radiation produces relatively high concentrations of very reactive radicals $\left(\mathrm{e} \cdot \mathrm{g} \cdot, \mathrm{H} \cdot, \mathrm{HO}^{\cdot}\right.$, and $\mathrm{HO}_{2}{ }^{\circ}$ ) as well as $\mathrm{H}_{2} \mathrm{O}_{2}$, by radiolysis of the water inside the resin beads. All these specles are thus able to attack all parts of the resin structure throughout the bead. In the case of dewatered resin treated with $\mathrm{H}_{2} \mathrm{O}_{2}$ solution, on the other hand, the radicals will not be present at all and the $\mathrm{H}_{2} \mathrm{O}_{2}$ w111 be able to attack only the outer bead surfäce until diffusion into the interior cän take place. Another important chemical species which is missing from the chemical $\mathrm{H}_{2} \mathrm{O}_{2}$ system is hydrogen gas which is produced from both resin and water by radiation.

A marked difference between the radiation and purely chemical systems is the manner of attack on the organic resin. None of the chemical bonds in the 
resin polymer molecules are immune to radiation. Most of the radiation damage begins with direct scission of $\mathrm{C}-\mathrm{C}$ and $\mathrm{C}-\mathrm{H}$ bonds, and the $\mathrm{C}-\mathrm{S}$ and $\mathrm{C}-\mathrm{N}$ bonds to the functional groups, to form free radicals of all sizes, from $H$ atoms to radicals of "molecular" welghts of many thousands. These radicals are then available for reactions with each other and with all the mobile species $\left(\mathrm{H}_{2} \mathrm{O}_{2}\right.$ and radicals) formed from water radiolysis. In the $\mathrm{H}_{2} \mathrm{O}_{2}$ chemical system, there is apparently a certain amount of $\mathrm{C}-\mathrm{C}$ bond attack, particularly when iron and/or copper ions are pressent to act as catalysts, but this attack is slow, with relatively 1 ow $\mathrm{H}_{2} \mathrm{O}_{2}$ concentrations. $\mathrm{H}_{2} \mathrm{O}_{2}$ attacks $\mathrm{C}-\mathrm{H}$ bonds in oxidation reactions, whereas in radiation systems abstraction of $H$ atoms by $H \cdot$ radicals to form $\mathrm{H}_{2}$ is a major contributor to the overall reaction.

It must therefore be concluded that use of chemical solutions cannot adequately simulate the chemical conditions, let alone the radiological conditions, specifled in the draft BTP.

\subsubsection{Use of Radiation}

From the foregoing discussion it becomes obvious that the only way to simulate radiological conditions, which will in the process simulate chemical conditions, is to irradiate the test sample with radiation of low LET similar to the $\beta, \gamma$-irradiation given by radionuclides to spent resins in practice. This can still only simulate actual radiation conditions, not reproduce them. There is no way to reproduce the low dose rates to resins at burial sites without carrying out experimental irradiations for many years. This matter of dose rate differences has been discussed at length in Section 3.3.3.

\subsection{Cholce of Irradiation Method}

Irradiation can be carried out either internally, by adding $B, \gamma$-radioactivity to the resin sample, or externally, by providing the radiation dose from an external source such as an electron accelerator or an X-ray or $\gamma$-source. Nuclear reactor irradiation is not suitable because the radiation provided has a large component of high LET radiation, i.e., energetic protons produced by collision of fast neutrons with hydrogen atoms in water and resin. Determination of absorbed dose in reactor irradiations is also extremely difficult.

\subsubsection{Internal Irradiation}

Internal irradiation would most closely simulate spent resin conditions. It could be carried out by loading a resin sample with the appropriate amount of a relatively short half-life isotope to give the resin the required dose upon essentially complete decay. The half-life would have to be short so that the radioactivity on the resin sample could decay essentially completely (at least 10 half-1ives) before the resin was tested, and so that the total time for the whole procedure was kept reasonable. A pure $\beta$-emitter would be preferable for this, since total dose could be determined quite accurately. Estimation of the $\gamma$-dose from a $\beta, \gamma$-emitter would be subject to appreciable error for a.small sample. However, there is a major disadvantage to use of internal radiation, even 
assuming an approprlate RN source could be found, and that is the complexity of working at least behind shielding, and perhaps in a hot cell, coupled with assoclated worker exposure.

\subsubsection{External Irradiation}

External irradiation has several advantages over internal. One is that dosimetry can be made quite accurate, and dose rates under various conditions are determined regularly at most electron accelerators, and $\gamma-r$ ay and $X-r$ ay irradiators. Another is that irradiations can be carried out with essentially no exposure to personnel. Still another is that there would be no radioactivity in the sample, whereas using an internal source, there might be residual radioactivity in the sample (either from the source isotope or an impurity) when the sample was being tested. From the technical point of view, external irradiation appears to be the preferred method. Also, it is felt that such an irradiation would be easier to monitor by a regulatory agency, and would likely be preferred by a power plant, since service irradiations can readily be arranged and are not expensive.

Regarding the cholce between fast electron irradiation and $\mathrm{X}$-ray or $\gamma$-irradiation, it is concluded that $X-r$ ay or $\gamma$-irradiation is preferable. For electron irradiation, the sample geometry would be crucial if anything like a uniform irradiation dose were to be achieved. The irradiation cell would also have to have a thin window to permit the electron beam to reach the sample. Neither of these constraints applies to $X-r$ ay and $\gamma$-irradiation. With both types a small sample will obtain a uniform radiation dose, and the cell wall thickness and cell construction are not critical.

\subsection{Sultable Properties on Which to Base a Test}

An essential criterion for choosing a property of the resin as a basis for a damage test is that the property must be one which would be possessed by any concelvable organic ion exchange resin that a generator might propose as a candidate. Since any resin proposed will be organic and will contain functional groups, 1t w111 generate gas due to absorption of radiation, and w111 lose functional groups, and thus exchange capacity. It may or may not possess the other properties which we have evaluated. The various properties are considered below in terms of the essential criterion and other bases for judging suitability.

\subsubsection{Changes in Appearance}

As pointed out In Sections 3.2.4.2, most changes in appearance, such as darkening of color; 'bead fracturing, and agglomeration, have been related to radiation dose in only a qualitative way, because of inability to make quantitative determinations of the effect. In the case of sweling, where quantitative determinations can be made, the degree of swelling ls a function both of percent cross-linking and of the concentration of the functional groups, which are hydrophylic. Under irradiation, the cross-linking and exchange capacity vary in a complex way so that swelling may occur at low dose and the effect 
reverse at higher doses. Thus, depending on the resin, for a given dose one might observe swelling, no change, or shrinkage.

The first three effects can be ruled out as the basis for a test because of the present inability to make quantitative determinations of their magnitude. Swelling would not necessarily meet the essential criterion, although it is difficult to envision an organic resin that would not exhibit some sort of swelling effect. In any case, it is judged not to be a good property on which to base a test because of the difficulty in knowing what level of resin damage goes along with what degree of volume change and therefore what the allowable level should be. With further work and a better understanding of the factors influencing this property, a suitable test could probably, be developed. However, on the basis of the information in the itterature, it is not presently acceptable.

\subsection{2 $\mathrm{pH}$ Change and Enhancement of Corrosion}

$\mathrm{pH}$ change cannot be considered a suitable effect on which to base a test for reasons similar to those applying to resin swelling, 1.e., inability to know at what level to set the allowable limt. The usual practice in power plants is to use a mixed bed of cation and anion resins, generally $1: 1$ cation:anion, for coolant cleanup. Irradiation of such a mixture appears to give only small $\mathrm{pH}$ changes after quite large doses, although fairly large changes occur with strong acid cation.exchangers alone. Thus considerable damage could be done to a resin mixture before a properly measurable change in $\mathrm{pH}$ occurred (giving the illusion of great stability) because the effect is not additive, $1 . e \cdot$, the $\mathrm{pH}$ change of the mixture is not the sum of the changes for cation and anion exchangers separately.

Since enhancement of corrosion depends on $\mathrm{pH}$, the conclusion must be that this effect cannot be the basis for a test as long as $\mathrm{pH}$ change is considered unsuitable. In any case, because of the nature of the corrosion process, enhancement of corrosion appears to be the least straightforward property to apply in a quantitative manner, aside entirely from any uncertainties regarding $\mathrm{pH}$ changes.

\subsubsection{Exchange Capacity}

It has already been pointed out that exchange capacity meets the essential criterion of being applicable to any potential resin candidate. It is a direct measure of the number of functional groups present, and loss of functional groups cause loss of exchange capacity. It was not deemed appropriate to base a maximum allowable dose on the behavior of this property, in that the loss of functional groups does not represent damage to the structural framework of the resin (Section 3.3.2.4). This, of course, has no bearing on its use in a standard test. Such a test should be completely suitable for this purpose in terms both of direct relationship between dose and measured effect, and of simplicity in the procedure. In this connection for example, only simple wet chemical methods would be required, and samples could probably be irradiated in alr. We feel, however, that a test more closely related to degradation of resin structure would be more appropriate, if a suitable one is avallable. 


\subsubsection{Gas Generation}

Gas generation also satisfies the essential criterion, in that any conceivable candidate resin will generate gas when irradiated. Hydrogen will always be generated, and methane also seems to be formed from both cation and anion resins, though in much smaller amounts. $\mathrm{CO}_{2}$ and $\mathrm{CO}$ are also formed from both types of resin. There seems to be no purpose in basing a test on measurement of only one gas, since that would require analysis, an extra step with additional chance of introducing errors into the measurement. Thus, from the point of view of both simplicity and accuracy, total gas should be measured.

The formation of both total gas and the major constituents $\left(\mathrm{H}_{2}, \mathrm{CO}_{2}\right.$, C0) has been found to be reasonalby linear with dose (Section 3.2.3 and Figure 3.1), although McFarland in recent work has reported evidence of a dose threshold in the formation of total gas, and a slight increase in the slope of the yield-dose curve with increasing dose (Section 3.2.4.1 and Figure 3.2). This does not affect the cholce of gas generation for purposes of a test, since a limiting value for allowable gas production can stilil be set when the production rate departs slightly from linearity. Also there is no problem with use of a mixture of anton and cation resins, since the gas production of the mixture is the sum of the amounts produced from irradiation of the individual resins.

In terms of simplicity of measurement, gas generation should also be suitable. Measurement of the amount of gas produced, although requiring only standard high vacuum equipment, will demand considerable care in making the experimental observations. This is not judged to be a difficult requirement to meet, and from all points of view, gas generation is felt to be completely suitable as the basis for a standard test.

\subsubsection{Final Choice of Measurment to be Used}

From the foregoing discussion of sultability of the various properties affected by radiation, the choice of property on which to base a test narrows down to exchange capacity and gas generation. Since it is felt that exchange capacity should be the basis only if no other property is sultable, and gas generation is judged completely suitable, we recommend that measurement of gas generated be used in the standard test for permitting exceptions to the maximum loading rule.

\subsection{Development of the Test}

A number of factors must be taken into account in developing a test procedure of this nature. In the following section we discuss those we feel are efther critical, or at least important.

\subsubsection{Specific Requirements}

1. An important requirement is that the resin be irradiated dry. This requirement has a two-fold purpose.' First, it provides a known 
standard form for the starting material without having to comply with the requirement of some arbitrary water content, and second, it avolds complications from formation of gas by radiolysis of water.

2. In connection with a standard form, a further requirement is that resins to be tested must be in the $\mathrm{H}^{+} / \mathrm{OH}^{-}$form rather than in salt form, since there can be considerable variation in gas yields between different forms.

3. In order to avold possible interaction of the resin sample with metal in a metal irradiation cell, the sample must be contained in a glass or quartz holder inside the cell. Use of a Pyrex irradiation cell avoids the problem.

4. Sample stze must be large enough to produce an accurately measurable amount of gas at the radiation dose the resin is designed to accept without degradation. Some representative figures are considerd in the next section (4.4.2) which deals with the allowable limit for gas production.

5. The radiation source must be efther an $X$-ray or $\gamma$-source to provide sufficiently penetrating radiation. With a fast electron source, a thin window would be required to permit the electrons to reach the sample. This poses problems in cell construction and in carrying out the irradiation in such a way as to provide a reasonably uniform dose to the sample, especially since the sample must be reasonably large. The thin window, particularly if of large area, would be a potential problem in terms of rupture under vacuum or above atmospheric pressure. With $X$-ray or $\gamma$-irradiation, sample geometry and size, and cell construction are not problems.

\subsubsection{Limit for Acceptable Amount of Gas Generation During Test}

The maximum amount of gas which can be generated by a candidate resin being proposed for exception to the maximum loading rule, has to be based on the amount considered normal for a dose of $10^{8}$ rad to the typical nuclear grade resins used by power plants. The reference resin is a $1: 1$ cation:anion mixture in the $\mathrm{H}^{+} / \mathrm{OH}^{-}$form as typically used for reactor coolant cleanup.

The only study on irradiation of cation resins, which produced quantitative data on gas generation from dry resin in the $\mathrm{H}^{+}$form appears to be that of Mohorcic and Kramer.(16) Their value for $\mathrm{H}_{2}$ production was $2.2 \mathrm{x}$ $10^{-6}$ moles/g of resin at $10^{8}$ rad, with $\mathrm{CO}$ and $\mathrm{CO}_{2}$ contributing another $3.5 \times 10^{-6} \mathrm{moles} / \mathrm{g}$, and $\mathrm{SO}_{2} 7.1 \times 10^{-6} \mathrm{moles} / \mathrm{g}$, for a total of $1.3 \mathrm{x}$ $10^{-5}$ moles/g. The $\mathrm{SO}_{2}$ value seems high in relation to $\mathrm{H}_{2}$ yield, since McFarland(6) reported only a very small amount of $\mathrm{SO}_{2}$ from his dewatered or moist cation resin. However, in McFarland's experiments, $\mathrm{SO}_{2}$ may have been retained in solution in the water in the restn matrix. Mohorclc irradiated his dry resin in an evacuated glass vial, the conditions to be used in our test, which should have allowed $\mathrm{SO}_{2}$ to be liberated. He also analyzed the generated 
gases by mass spectrometer, and it is difficult to see how he could confuse mass peaks from $\mathrm{SO}_{2}$ with those of the other gases. For these reasons, we feel that his gas yields for that particular resin (Dowex 50W) must be accepted, and we therefore take the value of $1.3 \times 10^{-5}$ moles $/ \mathrm{g}$ of resin as the total gas yield for a reference cation resin in the $\mathrm{H}^{+}$form.

For the anion resin, the results of Kazanjian and Horrel(15) give a value of $9.3 \times 10^{-6}$ moles of $\mathrm{H}_{2} / \mathrm{g}$ of resin at $10^{8}$ rad for dry Dowex-1 in the nitrate $\left(\mathrm{NO}_{3}{ }^{-}\right)$form. This compares with McFarland's values of $1.5 \mathrm{x}$ $10^{-5}$ moles of $\mathrm{H}_{2} / \mathrm{g}$ and $2.8 \times 10^{-5}$ moles of total gas $/ \mathrm{g}$ for dewatered or molst Dow SBR-OH in the borate form, and shows about the expected difference between molst and dry resin. Accordingly, Kazanjian's value is considered acceptable. There is so little quantitative information available on anion resins that it is not clear what to expect for the difference between dry $\mathrm{OH}^{-}$ and dry $\mathrm{NO}_{3}{ }^{-}$forms. The salt form is perhaps more stable, but in the absence of definite evidence to that effect, we feel the same value should be used for the dry $\mathrm{OH}^{-}$form as for the dry $\mathrm{NO}_{3}{ }^{-}$. Then, using the ratio of $\mathrm{H}_{2}$ to total gas of 0.54 obtained by McFarland leads to a value for total gas of $1.7 \times 10^{-5}$ moles of gas/g of resin for a reference anton resin in the $\mathrm{OH}^{-}$ form.

Based on the above yield values chosen for the reference individual anion and cation resins, the total gas yield for the reference $1: 1$ anion: cation mixture is $1.5 \times 10^{-5}$ moles of gas $/ \mathrm{g}$ of resin at $10^{8} \mathrm{rad}$. The figure is bound to be somewhat arbitrary, due to the uncertainties of several of the assumptions, but is certainly in the right range. In terms of volume at STP, this value would be $0.3 \mathrm{cc}$ of gas/g of resin.

\subsubsection{Test Procedure}

\section{Sample Irradiation Cells}

The irradiation cells can be constructed from Pyrex tubing of appropriate diameter. They must be large enough to hold approximately $20 \mathrm{~cm}^{3}$ samples of resins, but total void volume must be kept low so that the pressure of gas produced can be measured as accurately as possible. A side arm containing a break seal must be attached above the level to which the cell will be filled with sample. This will be used for connecting the cell to the gas measuring system after irradiation. The tubulation at the top of the cell should be of appropriate diameter for attaching to a vacuum system and for making a constriction for sealing of $\mathrm{f}$ the evacuated cel1. Pyrex irradiation cells of this type have recently been described.*.

Metal irradiation cells can be used, but require spectal parts, such as all metal valves and fittings, since no organic gaskets, 0-rings, valve packings, etc., can be placed in the irradiation fleld. Radiation damage to the

\footnotetext{
*K. J. Swyler and R. E. Barletta, "Irradiation of Zeolite Ion-Exchange Media," Draft Report, BNL-NUREG-30631, December 1981.
} 
organic components could cause loss of vacuum by leaking at the doses to. which the resin samples are to be irradiated. If metal cells are used, the resin samples should be placed in glass or quartz liners. inside the cells to avoid interaction of resin with the metal. The steps of the procedures are written in terms of glass cells. If metal cells are used the steps will be essentially the same, except that metal valves will be used in place of glass break seals and seals at constrictions.

\section{Sample Preparation}

a. The resin must be in the $\mathrm{H}^{+}$form if cation exchanger, $\mathrm{OH}^{-}$form if anion exchanger, or $\mathrm{H}^{+} / \mathrm{OH}^{-}$form if mixed cation/anion.

b. Thoroughly dry the resin by heating it at $110^{\circ} \mathrm{C}$ for 24 hours.

c. Weigh out, in a dry atmosphere, six samples of approximately $10 \mathrm{~g}$ each and place each sample in a separate Pyrex sample irradiation container.

d. Alternatively, in place of steps b and $c$, six samples of undried resin can be taken, of such a size that when dry, they will weigh approximately $10 \mathrm{~g}$ each. Place each in a separate, weighed Pyrex Irradiation cell and dry as in step b. Weigh the cells again to determine the weights of dry resin.

e. Attach the Pyrex cell to a glass vacuum system capable of use for volume calibration (the gas measurement system would be appropriate), and constrict the connecting tubulation so that it can be sealed under vacuum.

f. Evacuate the cell and determine its vold volume up to the constriction using dry $\mathrm{N}_{2}$ or other inert gas.

g. Outgas the sample and seal off the cell, under vacuum, at the constriction.

\section{Irradiation}

Place the irradiation cell in a position in the X-ray or gamma-ray irradiation facility where the dose has been accurately determined, and leave it until the desired dose has been reached. Three samples are to be 1rradiated to 108. rad total dose, and three samples to the dose the generator wishes to use to qualify his resin for an exception. An empty sample cell for use as a blank is also to be irradiated to the higher dose. The purpose of irradiating samples to $10^{8} \mathrm{rad}$ is to provide comparison with other resins, and to provide a further measure of confidence in the results at the higher dose.

\section{Measurement of Gas Produced}

a. The gas measurement system must contain a calibrated volume, which includes the pressure measuring device, simflar in magnitude to that 
of the void volume of the samples. The pressure measuring device could be a mercury manometer with ad fustable level on the gas measuring side to permit the volume to be kept constant. Other acceptable pressure measuring devices include a small volume metal vacuum guage or pressure transducer, reading in mm.

b. After irradiation, attach the side arm of the sample (or blank) irradiation cell to the gas measurement system with breaker in place.

c. Evacuate throughly and check for leaks. When the whole system is sound and evacuated, break the break seal and measure the pressure in $\mathrm{mm}$ in the whole system (Irradiation cell plus gas measuring system).

d. Calculate the specific amount of gas generated during irradiation of the resin according to the formula

$v_{G}=\frac{\left(V_{m}+v_{c}\right)}{m_{R}} \cdot \frac{p_{s}}{760} \cdot \frac{273}{T_{s}}$

where $V_{G}$ is the volume of gas produced at STP per $g$ of dry resin.

$V_{M}$ is the volume of the measuring system

$V_{c}$ is the vold volume of the irradiation cell

$m_{R}$ is the weight of dry resin

$P_{8}$ is the pressure in $\mathrm{mm}$ in the whole system

$T_{s}$ is the temperature of the system in $K$.

e. In order to qualify the resin for use at the higher dose used in the test Irradation, the value of $V_{G}$ must not exceed $0.3 \mathrm{cc}$ of gas at $\mathrm{STP} / \mathrm{g}$ of dry resin. 


\section{SUMMARY AND CONCLUSIONS}

\subsection{Power Plant Survey}

The resin usage questionnalre was returned by 23 power plants. The principal results of interest to this report are given below under several appropriate headings.

1. Resin Usage

- No plants reported use of Inorganic ion exchangers.

- Strong acid cation resins and strong base anfon resins of the polymerization type are the kinds in general use.

- Nuclear grade resins were used by most of those plants responding.

- The resins used for cleanup of reactor coolant by most plants were mixed anion and cation, usually in a $1: 1$ ratio, and in the $\mathrm{H}^{+} / \mathrm{OH}^{-}$form.

- No evidence of radiation damage to the resins was reported.

2. Radioactivity in Liquid Streams

- The highest radioactivity levels in liquid streams were reported in the reactor coolant and boron recycle. They we re 10-100 times higher than those in liquid radwaste and in the streams from spent fue 1 pools.

- Essentially all the activity in the reactor coolant is due to short-lived RNs. The longer lived fission and activation products, Cs-134, Cs-137 and Co-60, a re present at very low concentrations.

- There was considerable variation in the coolant RNs reported from different plants, however noble gas isotopes and I-132 through 135 a lmost always contribute the bulk of the activity.

- Levels of activity in the coolant at several plants were high enough that a significant dose could be delivered to the coolant cleanup resin from steady-state concentrations of the short-lived RNs sorbed or trapped by the bed.

3. RN Loadings on Resins for Disposal

- Spent resin from coolant cleanup generally had much higher RN loadings than resins from other demineralizer systems. 
- There was a wide variation in the RN loadings on coolant cleanup resin reported by the different plants. Typical loadings ranged from 0.1 to $30 \mathrm{Ci} / \mathrm{ft}^{3}$, while maximum loadings ranged from 0.3 to $60 \mathrm{Ci} / \mathrm{ft}^{3}$ of 1 sotopes with half-lives longer than 5 years. Both BWRs and PWRs showed this variation. The BWR range for maximum loading was 0.3 to $60 \mathrm{Ci} / \mathrm{ft}^{3}$ and the PWR range was 1 to $40 \mathrm{Ci} / \mathrm{ft}^{3}$.

- Five of the reporting plants have shipped resins loaded to $>10$ $\mathrm{Cl} / \mathrm{ft}^{3}$ and several others have produced spent resin loaded to $>10 \mathrm{Ci} / \mathrm{ft}^{3}$. Typlcal loadings we re sald to be less than maximum. Three of the plants reporting loadings $>10 \mathrm{Cl} / \mathrm{ft}^{3}$ on spent resin solidify before shipping, so the curie level of their shipped waste form would be less than that on the spent resin itself.

- The distribution of the relatively long-lived RNs varied from $>90 \%$ activation products ( $\mathrm{Co}-60, \mathrm{Mn}-54$, etc.) at some plants to $>90 \%$ fission products $\left(\mathrm{Cs}_{s}-134,137\right)$ at other plants.

- Sr-90 appears to be a minor constituent of the RNs on spent resins. It was mentioned by only three plants as being present. On $1 y$ one plant gave an analytical result, and that was $2.5 \%$ of the Cs-137. Personnel contacted at other plants stated that their $\mathrm{Sr}-90$ was low; at one plant it had never been as high as $1 \%$ of the $\mathrm{Cs}-137$.

- Several plants reported-TRU isotopes on spent resins, and at all but one the level: was sald to be $<10 \mathrm{nCl} / \mathrm{g}$. One plant gave analytical results showing $11.4 \mathrm{nCi} / \mathrm{g}$, but since they solldifled their resin, the final waste form contained $<10 \mathrm{nCi} / \mathrm{g}$ and was thus not TRU waste.

\section{Shipment of Spent Resin}

- Amounts shipped vary widely, belng generally much higher for BWRs than for PWRs. The former usually reported annual shipments of many thousand $\mathrm{ft}^{3} /$ reactor and the latter only several hundred $\mathrm{ft}^{3} /$ reactor.

- The plant reporting the highest maximum loading on a spent resin (60 Ci/ $\mathrm{ft}^{3}$ ) shipped $15,000 \mathrm{ft}^{3}$ total, of which only $100 \mathrm{ft}^{3}$ was the high level: coolant clean up resin.

- Most of the plants reporting ship dewatered resin, but six reported using solidification and one shipped in both dewatered and solid form. Several of those plants shipping large amounts solidifled them. 


\subsection{Published Information on Radiation Damage to Resins}

Experimental results from the literature on the effects of ionizing radiation on organic ion exchange resins were examined in an effort to obtain the information required to establish a maximum permissible loading for the resins disposed of by nuclear power plants. Only strong base anion resins and strong actd cation resins of the polymerization type were considered. The principal areas of interest were gas generation, loss of exchange capacity, changes in $\mathrm{pH}$, physical damage to resin beads (i.e., fragmentation), changes in flow properties (1.e., agglomeration), and enhanced corrosion of metals in contact with irradiated resins. The earlier literature reviewed by Gangwer, Goldstein, and Pillay (4) covers mostly the first three areas. Recent work (5-8) in connection with the program to clean up the contaminated water at TMI-II deals with all the areas except 1088 of exchange capacity. From both the earlier work and the recent work, more information is available on cation than on antion resins, but for both types a broader data base would be helpful for our purpose. Recommendations for research needed to provide a sultable data base are given in Section 3.5. Information from the literature of importance to this report is summarized below.

- Changes in appearance such as fracturing of resin beads and agglomeration have not been quantitatively measured, but qualitatively they serve as indicators of resin damage. These changes and darkening of color become noticeable in the vicinity of $10^{8} \mathrm{rad}$.

- Radiation damage to resins results in elther loss of functional groups or breaking of bonds in the structural framework of the resin polymer.

- Removal of functional groups by radiation causes loss of exchange capacity, formation of gas ( $\mathrm{SO}_{2}$ from cation resins and nitrogencontalning gases from anion resins), and changes in $\mathrm{pH}$. The latter are marked in cation resins in the $\mathrm{H}^{+}$form, but may be rather small in anion resins. No information could be found on effects in mixed resins.

- Both $\mathrm{pH}$ change and $108 \mathrm{~s}$ of exchange capacity can be measured in cation regins at radiation doses we 11 below $10^{8} \mathrm{rad}$, and of ten as low as 107. rad.

- Damage to the polymer structural framework leads to changes in the degree: of cross-11nkage and to generation of gases, particularly $\mathrm{H}_{2}$, $\mathrm{CO}$ and $\mathrm{CO}_{2}$, and $\mathrm{CH}_{4}$, from both cation and anton resins.

- Although irradiation of resin leads to net formation of gaseous product 8 , there' 18 marked deplettion of any oxygen present during the irradiation.

- Gas generation in general is greater from anion thán from cation resins. $\mathrm{H}_{2}$ seems always to be formed in the largest amount. Some 
of this $\mathrm{H}_{2}$ is a result of radiolysis of water in the resin matrix in moist resins, but in dry resins it obviously must come from the resin itse $1 \mathrm{f}$.

- Gas generation lends itself to accurate measurement and should thus be a good monitor of radiation damage. Results in the literature show some apparent conflict, but this is likely at least partly due to lack of a sufficient data base to cover all the forms of the resins for which information is required (e.g., acid/base forms, salt forms, dry, dewatered or moist, etc).

- Results of investigations reported in the literature support a nearly linear increase in gas generation with dose, with measurable amounts produced well below $10^{8} \mathrm{rad}$. One recent investigation(6) found an apparent threshold for gas production from both cation and anton resin of a bout $5 \times 10^{7}$ rad, but that has not been confirmed.

\subsection{Maximum Permissible Dose}

NRC's draft BTP suggesting a maximum permissible loading of $10 \mathrm{CI} / \mathrm{ft}^{3}$ on spent power plant resins for disposal pointed out that such a loading of Cs-137 would deliver a total dose of about $10^{8}$ rad to the resin. We feel that a rule on maximum loading should be given in terms of dose rather than curie level, since damage is a function of dose, but the dose will vary greatly for the same curle level depending on the RN or mixture of RNs involved. For the longer-lived RNs on the power plant spent resins, Co-60 and Cs-137, the maximum long-term doses to resin from $10 \mathrm{Ci} / \mathrm{ft}^{3}$ loadings would be $6.4 \times 10^{7}$ rad and $1.3 \times 10^{8} \mathrm{rad}$, respectively. Maximum doses can be readily calculated from the curle loadings by a method outlined by Swyler et a 1. $(8)$

In arriving at a maximum allowable dose, the reference resin, on the basis of power plant usage, was chosen to be a 1:1 cation:anion mixture of dewatered resin in the $\mathrm{H}^{+} / \mathrm{OH}^{-}$form. Changes of appearance such as color, bead fracturing and agglomeration become noticeable at a dose of around $10^{8}$ rad to resin in the reference state. On the basis of these qualitative effects a maximum permissible dose would then be $10^{8}$ rad. Loss of exchange capacity and $\mathrm{pH}$ change are felt not to be appropriate effects on which to base a rule. Gas generation, on the other hand is considered a sultable property for this purpose. The reference resin mixture is estimated to generate about $2.7 \times 10^{-5}$ moles of gas/g of resin at $10^{8}$ rad total dose. This is a measurable amount, but when generated over a period of many years in a burial site would present no significant hazard to the general public. However, to be conservative, and to avold higher generation rates which could be hazardous in the short-term due to hydrogen formation during handling at power plant or burial site, a maximum permissible dose has been chosen as $10^{8}$ rad.

The following points are relevent to the usage and treatment of reactor coolant cleanup resins. 
- Sr-90 appears not likely to be found on these resins to the extent of more than a few percent of the Cs-137 activity. However, since the Sr,Y-90 couple delivers a dose per curie double that of Cs-137 and four times that of Co-60, power plants should analyze the $1 \mathrm{r}$ coolant cleanup resins (and any other high-level resins) for $\mathrm{Sr}-90$ and report the amount with the other RNs. Further, the contribution from Sr, Y-90 should be explicity included in dose calculations.

- Short-lived RNs in the reactor coolant can build up steady state saturation levels on the coolant cleanup resins high enough to give the resin a dose approaching $10^{7}$ rad in six months of continuous operation. This is probably less than the uncertainty with which plants will be able to estimate long term doses of $10^{8} \mathrm{rad}$, so is not a determining factor in setting a maximum dose limit. However, it is an indication that the $11 \mathrm{mit}$ of $10^{8} \mathrm{rad}$ based on long lived isotopes is not too conservative, since the resin obtains doses from other sources.

- Finally, limited information available in the literature(5) suggests a higher maximum loading for solidified resins might be possible. A1though such higher loadings might improve economics through volume reduction, more extensive research is necessary to establish a technical basis to allow such loadings. Recommendations for that research are included in Section 3.7.3.

\subsection{Development of Test Procedure for Exceptions to the Maximun Dose Rule}

A test procedure has been written (Section 4.4.3) based on gas generation from a dry resin. The reference resin used for estimating the amount of gas generation to be permitted in the test irradiation is a $1: 1$ cation: anion $\mathrm{mix}-$ ture in the $\mathrm{H}^{+} / \mathrm{OH}^{-}$form. The amount of gas estimated to be formed from such a resin mixture at a total dose of $10^{8}$ rad was $0.3 \mathrm{cc}$ of gas at STP $/ \mathrm{g}$ of dry resin.

Measurement of changes in exchange capacity may also be sultable as the basis for a test. The test would involve only simple wet chemical methods, and irradiations could probably be carried out in air rather than in vacuum as required for the gas generation test.

Some of the data required for estimating the amount of gas to be permitted in the test, and also the maximum total dose to be permitted in resins for disposal, were not avaflable in the 1iterature and had to be extrapolated from results obtained with resins of another form or different water content. Information on anion resins is particularly limited. To remedy this situation, recommendations are given in Section 3.5 for additional research needed to provide an adequate data base. 

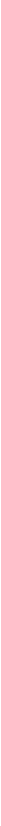


\section{REFERENCES}

1. K. H. Lin, "Use of Ion Exchange for the Treatment of Liquids in Nuclear Power Plants," ORNL-4792, December 1973.

2. $\quad$ w. E. Clark, "The Use of Ion Exchange to Treat Radioactive Liquids in Light-Water-Cooled Nuclear React or Power Plants," NUREG-CR-0143, 1978.

3. E. V. Egorov and P. D. Novikow, "Action of Ionizing Radiation on Ion Exchange Materials," Atomizdat, Moscow, 1975, Israel Program for Scientif1c Trans lations, Je rusalem, 1967.

4. T. E. Gangwer, M. Goldstein, and K.K.S. Pillay, "Radiation Effects on Ion Exchange Materia 1s, BNL-50781, 1977.

5. R. E. Barletta, K. J. Swyler, S. F. Chan, and R. E. Davis, "Solldification of Irradiated Eplcor-II Waste Products," BNL-NUREG-29913R, October 1981.

6. R. C. McFarland, "Analysis of Irradiated Ion Exchange Materials," Final Research Report, reproduced as Appendix C of "Propertles of Radioactive Wastes and Waste Containers, Status Report October-December 1981," NUREG/CR-2617, BNL-NUREG-51515, May 1982.

7. K.K.S. P1llay, "Radiation Effects on Ion Exchangers Used In Radioactive Waste Management," reproduced as Appendix A of "Properties of Radioactive Wastes and Waste Containers, Quarterly Progress Report July-September 1980, NUREG/CR-1863, BNL-NUREG-51316, Janua ry 1981.

8. K. J. Swyler, R. E. Barletta, and R. E. Davis, "Review of Recent Studies of the Radiation Induced Behavior of Ion Exchange Media," BNL-NUREG-28682, Novem ber 1980.

9. NRC Draft Branch Technical Position on Waste Form, Enclosure In Letter of R. E. Browning to Waste Generators, October 30,1981 .

10. P. E. Tulupov, A. M. Butaev, V. P. Yreben, and A. I. Kasprovich, "Effect of Content of Divinylbenzene in KU-2 Cation-Exchange Resin on Its Resistance to Irradiation In Water," Russian J. Phys. Chem. (English Translation) $47(4), 551-553$ (1973).

11. J. W. Utley, "The Chemical Effects of Low Energy X-Radiation on Ion Exchange Resins," Part I of Ph.D. thesis submitted to the faculty of the graduate school of Vander bilt University, Nashville, TN, June 1959.

12. T. Ichikawa and Z. Hagiwara, "Effect of Gamma Radiation on Cation Exchange Resin," J. Nucl. Sci. Tech. 10, 746-52 (1973).

13. G. J. Moody and J.D.R. Thomas, "The Stability of Ion Exchange Resins: Part II-Radiation Stability," Laboratory Practice 21(10), 717-722 (1972). 
14. R. H. Wiley and G. Devenuto, "Irradiation Stability of Sulfonated Styrene Resins Cross-1inked With Various Divinylbenzene Isomers and Mixtures There of ," J. App1. Polym. Sc1. 9, 2001-2007 (1965).

15. A. R. Kazanjian and D. R. Horrell, "Radiation Ef fects on Ion-Exchange Resins-II. Gamma Irradiation of Dowex 1," USAEC Report RFP-2345, Rocky Flats Division, Golden, Co, 1975.

16. G. Mohorcic and V. Kramer, "Gases Evolved by ${ }^{60}$ Co Radiation Degradation of Strongly Acidic Ion Exchange Resins," J. Polymer Science, Part C 16, 4185-4195 (1968).

17. G. Mohorclc, and V. Kramer and M. Pregelj, "Interaction of a Sulfonic Acid Ion Exchange Resin with Tritiated Water on Gamma-Irradiation," Int. J. App1. Rad. and Isotopes, 25, 177-182 (1974).

18. A. R. Kazanjlan and D. R. Horrell, "Radiation Effects on Ion-Exchange Resins-I. Gamma Irradiation of Dowex 50 XW," USAEC Report RFP-2140, Rocky Flats Division, Golden, CO, 1974.

19. R. C. McFarland, "The Effects of Gamma Radiation on Ion Exchange Resins and Activated Charcoal," TMI-II-RR-6, 1980.

20. R. L. Clough and K. T. Gillen, "Combined Environmental Aging Effects: Radiation-Therma 1 Degradation of Polyvinyl Chloride and Polyethylene," J. Polymer Science, Polymer Chemistry Edition 19, 2041-2051 (1981).

21. Bureau of Radiological Health and the Training Institute, Environmental Control Administration, Radiological Health Handbook, U.S. Government Printing office, Washington, D.C., 1970 .

22. G. J. Hine and G. L. Browne11, Radiation Dosimetry, Academic Press, Inc., New York, 1956.

23. H. E. Filter, "Vinyl Ester Solidification of Low-Level Radioactive Waste," Dow Chemical Company report, November 1979. 
APPENDIX A

1. Blank Copy of Questionna1re of Ion Exchange Resin Usage In Nuclear Power Plants.

2. Summary of Responses of Particular Interest to this Report. (The responses obtained from some of the power plants have been supplemented by information obtained by telephone contact with plant personnel.) 
SURVEY OF ION EXCHANGE RESIN USAGE IN NUCLEAR POHER PLANTS

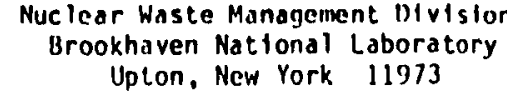

1. Plant name

Unit (s)/Type

Utility Company

2. Demtnerallzer system:

\section{Condensate or} Boron Recycle

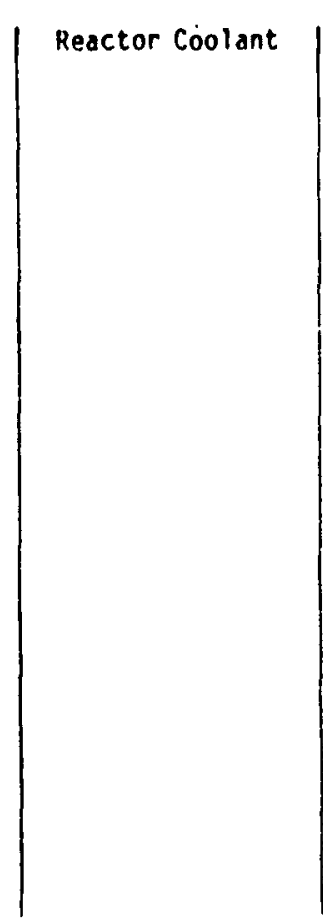

Radwaste

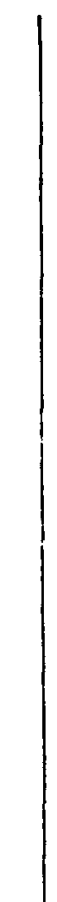

Fuel Pool

other

3. Type of operation:

Deep bed, Powdex, etc.

(Spectfy combinations)

4. Type of bed:

Cation, anton, mixed

If mixed, stratified or homogeneous beds? $\%$ cation $/ \%$ anton

Bed dimensions

Volume of resin in bed

5. Resin(s) Identification:

Manufacturer/Vendor

Tradename(s)

Iontc form used in bed

(e.9., $\mathrm{H}^{+}, \mathrm{OH}^{-}, \mathrm{Li}^{+}$, etc.)

6. Do you use any inorganic ton exchange resins? (Please spectfy)

7. Do resins recelved from manufacturer/vendor contain any freestanding liquids? 
8. Characteristics of Influent: Flow rato (gpm)

Temp ( $\left.{ }^{\circ} \mathrm{F}\right)$

Pressure (psig)

$\mathrm{pH}$ :

Conduct Ivity ( unho/ $\mathrm{cm}$ )

Gross a activity; ( $\mu \mathrm{Ct} / \mathrm{mL}$ )

Gross $B, Y$ activity $(\mu \mathrm{Ci} / \mathrm{mL})$

Princtpal radionuclides ( $\mu \mathrm{Cl} / \mathrm{mL}$ )

(Attach list tfiavaflabie).

Total suspended sollds (ppb)

Contaminants:

Chemical spectes (e.g., $\mathrm{Cl}^{-}$, siltca, etc.)

other materials (e.g, detergents, o11, etc.)

9. Characteristics of effluent:

Flow rate (gpm)

Temp ( $\mathrm{O} F$ )

G

pH

Conduct ivity $(u \mathrm{mho} / \mathrm{cm})$

Gross a activity $(\mu \mathrm{Cl} / \mathrm{mL})$

Gross $B, Y$ act Ivity (i Ci/mi)

Princlpal radionuclides $(\mu \mathrm{C} 1 / \mathrm{mL}$ )

(Attach list if avallable)

Total suspended solids (ppb)

Contaminant s:

Chemical species (e,g., $\mathrm{Cl}-\mathrm{i}$ stl.tca, etc.)

other materials (e.g., detergents, oll, etc.)

10. Resin replacenént:

Criteria for replacement $(\Delta P$, conductivity, etc.) [Specify value(s)]

Dose rate at surface of bed vessel ( $(R / h r)$

Evidence of radiation damage

(e.g., agglomeration, gas generation,

color changes, etc.) 
11. Spent resin holding tank(s):

Number
Volunte
Phystcal

Physical structure (e.g., conical bottom, etc.)

Spectal features (e.g. . nitrogen purging, etc.)

Mechanical properties (e.g., pressure 1 imit, etc.)

Construction material (e.g., stainless steel, etc.)

Are resins from different beds mixed or stored separately?

If $m$ ixed, specify combinations

Maximum time resin stored here

12. Characteristics of water in spent resin holding tank:

Conduct fvity (umho/cm)

Gross a activity ( $\mu \mathrm{C} 1 / \mathrm{mL})$

Gross $\dot{\beta}, \gamma$ act ivity ( $L C 1 / \mathrm{mL})$

Principal radionuclides $(\mu \mathrm{C} 1 / \mathrm{mL}$ )

(Attach list if avaliable)

Total suspended solids (ppb)

Cont aminants:

Chemical spectes (e.g., $\mathrm{Cl}^{-}$, stlica, etc.)

other materials (e.g.. detergents, o1l, etc.)

13. Dewatering information:

Process (e.g., centrifugation, etc.)

Are resins dewatered in container used for disposal?

Are resins dewat
Any problems?

14. Dewatered resin:

Gross a activity $(\mu \mathrm{Cl} / \mathrm{mL})$

Gross $\beta$, Yact Ivity $(\mu \mathrm{Cl} / \mathrm{mL})$

Annual volume of resin for disposal

15. Container used for disposal of dewatered resins: Manufacturer/Vendor:

Dimenstons

Vol ume

Phystcal structure (e.g., confcal bottom, etc.)

Special features (e.g., underdrain, etc.)

Spectal reatures (e.g., underdrain, etc.)

Construction material (e.g., stainiess steel, etc.)

Mechanical properties (e.g., pressure limits, etc.)

Volume of restn in contatne 
16. Do you plan to use a high integrity container in the future?

17. For non-solfdifted resins stored on site:

Average total volume stored

Average storage time

Location and conditions (Indoor/outdoor, temperature range, etc.)

18. During storage on site, ore contalners checked perlodically for changes in:

Freestanding liquid (volume, pll, etc)?

Gross a activity?

Gross $B, Y$ oct Ivity?

Temperature?

Pressure?

Container integrity (e.g., leakage, corrosion, etc.)?

(Spectfy any values determined.)

Which of the above changes (or any others) are attributed to radiation damage?

9 19. Prior to shipment, are containers with non-solidifled resins checked for changes in: Freestanding liquid (volume, pH, etc.)

Gross a activity?

Gross $B, Y$ act I vity?

Temperature?

Pressure?

Container Integrity (e.g., leakage, corrosion, etc.)?

(Specify any values determined.)

Which of the above changes (or any others) are attributed to radiation damage?

20. Est/mate the maximum activity $\left(\mathrm{Cl} / \mathrm{ft}^{3}\right)$ on spent resin in a liner shipped to date.

21. Estimate the maximum activity $\left(\mathrm{Ct} / \mathrm{ft}^{3}\right)$ on spent resin in bed to date.

22. Do any of the resins recelve radiation from an external source? (Please specify.)

Page 4 of 5 

23. Final disposal site(s):
- Barnwell, SC
o Reatty. NV
- Hanford, wn

24. Name and telephone number of person to whom questions can be addressed.

25. Additional comments on expertence with ton exchange resins regarding: the drainable liquids and radiation damage to the resins. 
Table A.1

Summany of Pertinent Results From Survey of Organic Ion Exchange Resin Usage by LWRs

\begin{tabular}{|c|c|c|c|c|c|c|}
\hline$, \quad, \quad \ldots$ & $\begin{array}{l}\text { Type of Resin } \\
\text { Used for Treating } \\
\text { Redctor Coolant }\end{array}$ & $\begin{array}{l}\text { Type of } \\
\text { Operation }\end{array}$ & $\begin{array}{c}\text { Activity in } \\
\text { Coolant Water } \\
\mu \mathrm{C} / \mathrm{mL}\end{array}$ & $\begin{array}{l}\text { Principal } \\
\text { Radionuclides } \\
\text { in Coolant }\end{array}$ & $\begin{array}{c}\text { Dose Rate } \\
\text { at Surface } \\
\text { of Bed Vessel } \\
\text { R/h }\end{array}$ & $\begin{array}{l}\text { Criteria } \\
\text { for Resin } \\
\text { Repldictuent }\end{array}$ \\
\hline \multicolumn{7}{|l|}{ BWRs } \\
\hline Brown's Ferry & $\begin{array}{l}\text { Mixed, } 1: 1 \\
\text { Catton: anion } \\
H+, O H-\text { form }\end{array}$ & Powdex & not answered & not answered & not avallable & $\begin{array}{l}\text { conductivity } \\
>0.1 \text { bitho }\end{array}$ \\
\hline $\begin{array}{c}\text { Cooper } \\
\qquad .\end{array}$ & $\begin{array}{l}\text { Mixed } \\
\text { cation: anton } \\
H+\text {, OH- fom }\end{array}$ & Powdex & $0.1 \mathrm{in}$ effluent & 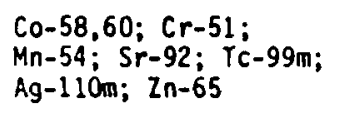 & not avallable & $\begin{array}{l}\text { conductivity, } \\
\text { sp, or } 8-d d y \\
\text { service }\end{array}$ \\
\hline Dresden & $\begin{array}{l}\text { Mixed, } 2: 3 \\
\text { catton: anton }\end{array}$ & Deep Bed & $\begin{array}{l}1 \mathrm{in} \text { influent } \\
0.1 \mathrm{in} \text { effluent }\end{array}$ & $\begin{array}{l}1-131,132,133,134,135 ; \\
B a-139,140,141 ; \text { Sr-91, } \\
92 ; C 5-138 ; \mathrm{Mo}-99 ; \\
T c-101,104\end{array}$ & $50-200$ & $\mathrm{SHO}_{2}>0.3 \mathrm{ppm}$ \\
\hline Duane Arnold & $\begin{array}{l}\text { Mixed } 2: 3 \\
\text { cation: anton }\end{array}$ & Powdex & not answered & $\begin{array}{l}\mathrm{Cr}-51 ; \mathrm{Mn}-54 ; \mathrm{Co}-58, \\
60 ; \mathrm{Fe}-59 ; \mathrm{Na}-24\end{array}$ & not avallabe & $\Lambda_{p}$ \\
\hline Edwin 1. Hatch & $\begin{array}{l}\text { Mixed } 1: 1 \\
\text { cation: anion }\end{array}$ & Powdex & $\begin{array}{l}0.1 \text { in influent } \\
0.001-0.01 \text { in } \\
\text { effluent }\end{array}$ & not answered & not answered & $\begin{array}{l}\text { conductivity or } \\
7 \text {-day service }\end{array}$ \\
\hline James A. Fitzpatrick & $\begin{array}{l}\text { Mixed 1:1 } \\
\text { cation: anton }\end{array}$ & Powdex & not answered & not answered & not answered & $\begin{array}{l}\mathrm{High} \mathrm{SiO}_{2} \\
\text { conductivity }\end{array}$ \\
\hline Millistone & $\begin{array}{l}\text { Mixed 2:3 } \\
\text { cation: ạnton }\end{array}$ & Deep Bed & $\begin{array}{l}0.1-1 \text { in influent } \\
10^{-4} \text { in effluent }\end{array}$ & $\begin{array}{l}\mathrm{Co-}_{00} ; \mathrm{Cs}_{5}-134,137 ; \\
\text { Fe-55; } \mathrm{Mn}-54\end{array}$ & not known & $\begin{array}{l}\therefore p>30 \text { psi } \\
\text { cl- retihoval } \\
\text { capdcity }\end{array}$ \\
\hline Monticello & $\begin{array}{l}\text { Mixed 1:1 } \\
\text { cation: anton } \\
\mathrm{H}+\text {, OH- }\end{array}$ & Powdex & not answered & not answered & not answered & 2 weeks service \\
\hline Peach Bottom & $\begin{array}{l}\text { Mixed 1:1 } \\
\text { cation: anton }\end{array}$ & Powdex & $0.05-2$ in influent & not answered & $7-12$ (fuel pool) & $\begin{array}{l}\therefore p=25 p s i \\
\text { conductivity }\end{array}$ \\
\hline Venmont Yankee & Mixed & Powdex & not answered & not answered & $\begin{array}{l}\text { not able to } \\
\text { answer }\end{array}$ & conductivity \\
\hline \multicolumn{6}{|l|}{ PWRs } & IOW DF \\
\hline Calvert Cliffs & $\begin{array}{l}\text { Mixed } 1: 1 \\
\text { cation: anton } \\
\mathrm{H}+\mathrm{OH}_{-}\end{array}$ & Deep Bed & not answered & not answered & not answered & \\
\hline Fort Calhoun & $\begin{array}{l}\text { Mixed 1:1 } \\
\text { cation: anion }\end{array}$ & Deep Bed & 1.9 in influent & $\begin{array}{l}1-131,132,133,134 \\
135 ; C_{s}-138 ; C_{0}-58 \\
M n-54\end{array}$ & not answered & low DF \\
\hline
\end{tabular}


Table A.1, Continued

Sumunary of Pertinent Results From Survey of Organic Ion Exchange Resin Usage by LHRs

\begin{tabular}{|c|c|c|c|c|c|c|}
\hline & $\begin{array}{l}\text { Type of Resin } \\
\text { Used for Treating } \\
\text { Reactor Coolant }\end{array}$ & $\begin{array}{l}\text { Type of } \\
\text { Operation }\end{array}$ & $\begin{array}{c}\text { Activity in } \\
\text { Coolant Water } \\
\mu \mathrm{Ci} / \mathrm{mL}\end{array}$ & $\begin{array}{l}\text { Principal } \\
\text { Radionuclides } \\
\text { in Coolanta }\end{array}$ & $\begin{array}{c}\text { Dose Rate } \\
\text { at Surface } \\
\text { of Bed Vesselo } \\
\text { R/h }\end{array}$ & $\begin{array}{l}\text { Criterid } \\
\text { for Resin } \\
\text { Replacement }\end{array}$ \\
\hline Donald C. Cook & $\begin{array}{l}\text { Mixed } \\
\text { cation: anton }\end{array}$ & Deep Bed & $\begin{array}{l}0.2 \text { in influent } \\
0.02 \text { in ef fluent }\end{array}$ & $\begin{array}{l}\text { CS-138; Rb-88,89; } \\
\text { Na-24; I-131,133; } \\
Y-88 ; M n-54\end{array}$ & 500 & $\begin{array}{l}\text { Replace at each } \\
\text { operating cycle }\end{array}$ \\
\hline Joseph M. Farley & $\begin{array}{l}\text { Mixed } 3: 2: 3 \\
\text { cation: anion: } \\
\text { lithiated }\end{array}$ & Deep Bed & not answered & not answered & & \\
\hline Kewaunee & $\begin{array}{l}\text { Mixed } 1: 1 \\
\text { cation: anton } \\
\text { plus separate } \\
\text { cation and anion }\end{array}$ & Deep Bed & $\begin{array}{l}0.1 \text { in influent, } \\
0.02 \text { in ef fluent }\end{array}$ & $\mathrm{Na}-24, \mathrm{~F}-18$ & $\begin{array}{l}\text { not able to } \\
\text { medsure }\end{array}$ & Low DF \\
\hline Maine Yankee & $\begin{array}{l}\text { Mixed } 1: 1 \\
\text { cation: anton } \\
\mathrm{H+}, \mathrm{OH}-\end{array}$ & Deep Bed & 1 in influent & $\begin{array}{l}\text { Co-58,60; Mn-54; } \\
\text { iodines, cesiums, } \\
\text { and rubidiums }\end{array}$ & $500-1000$ & $D F<1.0$ \\
\hline Point Beach & $\begin{array}{l}\text { Mixed, cation } \\
\text { and anton }\end{array}$ & Deep Bed & 0.3 in infiuent & $\begin{array}{l}1-131,132,133,134 \\
135 ; \mathrm{Cs}-138 ; \mathrm{Rb}-88 \\
\mathrm{~F}-18 ; \mathrm{Na}-24\end{array}$ & not answered & Low OF \\
\hline Prairie Island & $\begin{array}{l}\text { Mixed } 1: 1 \\
\text { cation, anton } \\
\text { L1+, OH- }\end{array}$ & Deep Bed & not answered & not answered & not answered & LOW DF \\
\hline St. Lucie & $\begin{array}{l}\text { Mixed } 2: 1 \\
\text { cation: anion } \\
\mathrm{H+}, \mathrm{OH}_{-}\end{array}$ & Deep Bed & 1.74 in influent & $\begin{array}{l}\text { I-131,132,133,134; } \\
135 ; \mathrm{Rb}-88 ; \mathrm{Mo}-99 ; \\
\mathrm{Cs}-138 ; \mathrm{Te}-132 ; \mathrm{Y}-91\end{array}$ & not answered & Low OF \\
\hline Trajan & $\begin{array}{l}\text { Cation and Mixed } \\
\mathrm{Lit}_{+} \mathrm{H+} \text {, and } \mathrm{OH}_{-}\end{array}$ & Deep Bed & $2-100$ & not answered & not answered & Low DF \\
\hline Yankee-Rowe & $\begin{array}{l}\text { Mixed } 2: 3 \\
\text { cation: anton } \\
\mathrm{H}+, \mathrm{OH}-\end{array}$ & Deep Bed & $\begin{array}{l}1 \text { in influent } \\
0.01 \text { in ef fluent }\end{array}$ & $\begin{array}{l}\text { Cs-138; I-131,132 } \\
133,134,135 ; \mathrm{Ba}-139 \\
\mathrm{Na}-24 ; \mathrm{Mn}-54 ; \mathrm{Se}-75 \\
\mathrm{Co-58;} \mathrm{Nb}-95\end{array}$ & $5-100$ & $\Delta p$ \\
\hline Zion & $\begin{array}{l}\text { Mixed } 1: 1 \\
\text { catton: anton } \\
\mathrm{Lit}, \mathrm{OH}-\end{array}$ & Deep Bed & $\begin{array}{l}0.05-0.5 \mathrm{in} \\
\text { influent; } 0.001 \\
\text { in effluent }\end{array}$ & $\begin{array}{l}\text { Co-58,60; Cr-51; } \\
\text { Cs-134,138; Ba-140; } \\
\text { Ho-99; Zn-65; I-132 }\end{array}$ & $\sim 100$ & Low DF \\
\hline
\end{tabular}


Table A.2

Summary of Pertinent Results From Survey of Organic Ion Exchange Resin Usage by LWRs

\begin{tabular}{|c|c|c|c|c|}
\hline & $\begin{array}{l}\text { Evidence of } \\
\text { Radiation } \\
\text { Damage }\end{array}$ & $\begin{array}{c}\text { Activity on } \\
\text { Dewatered Resin } \\
{ }_{\mu} \mathrm{C} i / \mathrm{mL} \text { a }\end{array}$ & $\begin{array}{l}\quad \text { Principal } \\
\text { Radionuclfdes on } \\
\text { Dewa tered Resina,b }\end{array}$ & $\begin{array}{l}\text { Method } \\
\text { of } \\
\text { Disposal }\end{array}$ \\
\hline $\begin{array}{l}\text { BWRs } \\
\text { Brown's Ferry }\end{array}$ & none & 2.5 & & dewa tered resin \\
\hline Cooper & none & 0.1 & & $\begin{array}{l}\text { solidification } \\
\text { in concrete }\end{array}$ \\
\hline Dresden & none & not known & $\begin{array}{l}\mathrm{C}_{0-58,60 ;} \mathrm{Mn}-54 \\
\mathrm{Cs}-134,137\end{array}$ & $\begin{array}{l}\text { solidification } \\
\text { in concrete }\end{array}$ \\
\hline Duane Arnold & none & maximum 85 & not answered & $\begin{array}{l}\text { Hittman solidifi- } \\
\text { cation system }\end{array}$ \\
\hline Edwin I. Hatch & not answered & $100-1000$ & $\begin{array}{l}\text { Cs-134,137; } 2 n-65 ; \\
\text { Co-58,60 }\end{array}$ & solldification \\
\hline James A. Fitzpatrick & not answered & & & dewatered resin \\
\hline M1llstone & none & 1 to 6 & & dewatered resin \\
\hline Monticello & not answered & 1 & & $\begin{array}{l}\text { solidification } \\
\text { in cement }\end{array}$ \\
\hline Peach Bottom & none & 2 to 20 & $\begin{array}{l}2 n-65 ; C 0-58,60 \\
\text { Cs-134,137; Cr-51; } \\
1-131 ; M n-54\end{array}$ & dewatered resin \\
\hline Venmont Yankee & not answered & 140 & $\begin{array}{l}\text { Cs-134,137; } 2 n-65 ; \\
\mathrm{Co}_{0}-58,60 ; 2 r-95 ; \mathrm{Mn}-54\end{array}$ & dewatered resin \\
\hline $\begin{array}{l}\text { PWRs } \\
\text { Beaver Valley }\end{array}$ & none & & 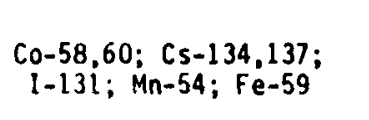 & dewatered resin \\
\hline Calvert Cliffs & not answered & & & dewatered resin \\
\hline Fort Calhoun & not answered & & & dewatered resin \\
\hline
\end{tabular}


Table A.2, Continued

Summary of Pertinent Results From Survey of Organic Ion Exchange Resin Usage by LWRs

\begin{tabular}{|c|c|c|c|c|}
\hline & $\begin{array}{l}\text { Evidence of } \\
\text { Radiation } \\
\text { Damage }\end{array}$ & $\begin{array}{c}\text { Activity on } \\
\text { Dewatered Resin } \\
\mu \mathrm{C} 1 / \mathrm{mL}^{\mathrm{a}}\end{array}$ & $\begin{array}{l}\text { Princtpal } \\
\text { Radtonuclides on } \\
\text { Dewatered Resind, }\end{array}$ & $\begin{array}{l}\text { Method } \\
\text { of } \\
\text { Disposal. }\end{array}$ \\
\hline $\begin{array}{l}\text { PWRs, Continued } \\
\text { Donald C. Cook }\end{array}$ & none & $\sim 50$ & $\begin{array}{l}C_{0-58,60 ; C s-134,137} \\
\text { Mn-54; SD-124 }\end{array}$ & dewatered resin \\
\hline Joseph M. Farley & none & 1 to 100 & $\begin{array}{l}\mathrm{Co}-58,60 ; \mathrm{Mn}-54 ; \\
\mathrm{Cs}-137 ; \mathrm{H}-3\end{array}$ & dewatered resin \\
\hline Kewaunee & none & & & solidification \\
\hline Maine Yankee & none & 1000 to $5000^{c}$ & 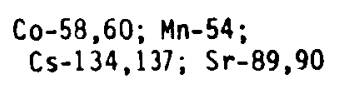 & dewatered resin \\
\hline Point Beach & none & & $\begin{array}{l}C_{0}-58,60 ; C s-134,137 \\
\text { Sb-125; Ru-106; Mn-54 } \\
\text { Cr-51 }\end{array}$ & dewatered resin \\
\hline Prairie Island & not answered & 2 to 10 & & dewatered resin \\
\hline St. Lucie & not answered & up to 140 & , & dewatered resin \\
\hline Trajan & not answered & 35 & $\begin{array}{l}\mathrm{Co}-58,60 ; \mathrm{Cs}-134,137 \\
\mathrm{Mn}-54 ; \mathrm{Ce}-144\end{array}$ & $\begin{array}{l}\text { dewatered resin } \\
\text { and solidification }\end{array}$ \\
\hline Yankee-Rowe & none & $\begin{array}{l}\text { typical } 0.1-5 \\
\text { up to } 50\end{array}$ & & dewatered resin \\
\hline Zion & none & & $\begin{array}{l}\text { Co-58,60; Mn-54; } \\
\text { Cs-134,137; I-131; } \\
\text { Cr-51 }\end{array}$ & solidification \\
\hline
\end{tabular}

a In general, on resin from reactor coolant cleanup.

bprincipal RNs listed in approximate order of abundance by element. Where there is more than one isotope of the same element, they are listed together for convenience, although one or more isotopes may be out of order in terms of abundance.

$c_{\text {Largely }} \mathrm{C} 0-58$ (half -1 f fe of 71 days). 
Table A.3

Summary of Pertinent Results From Survey of Organic Ion Exchange Resin Usage by LWRs

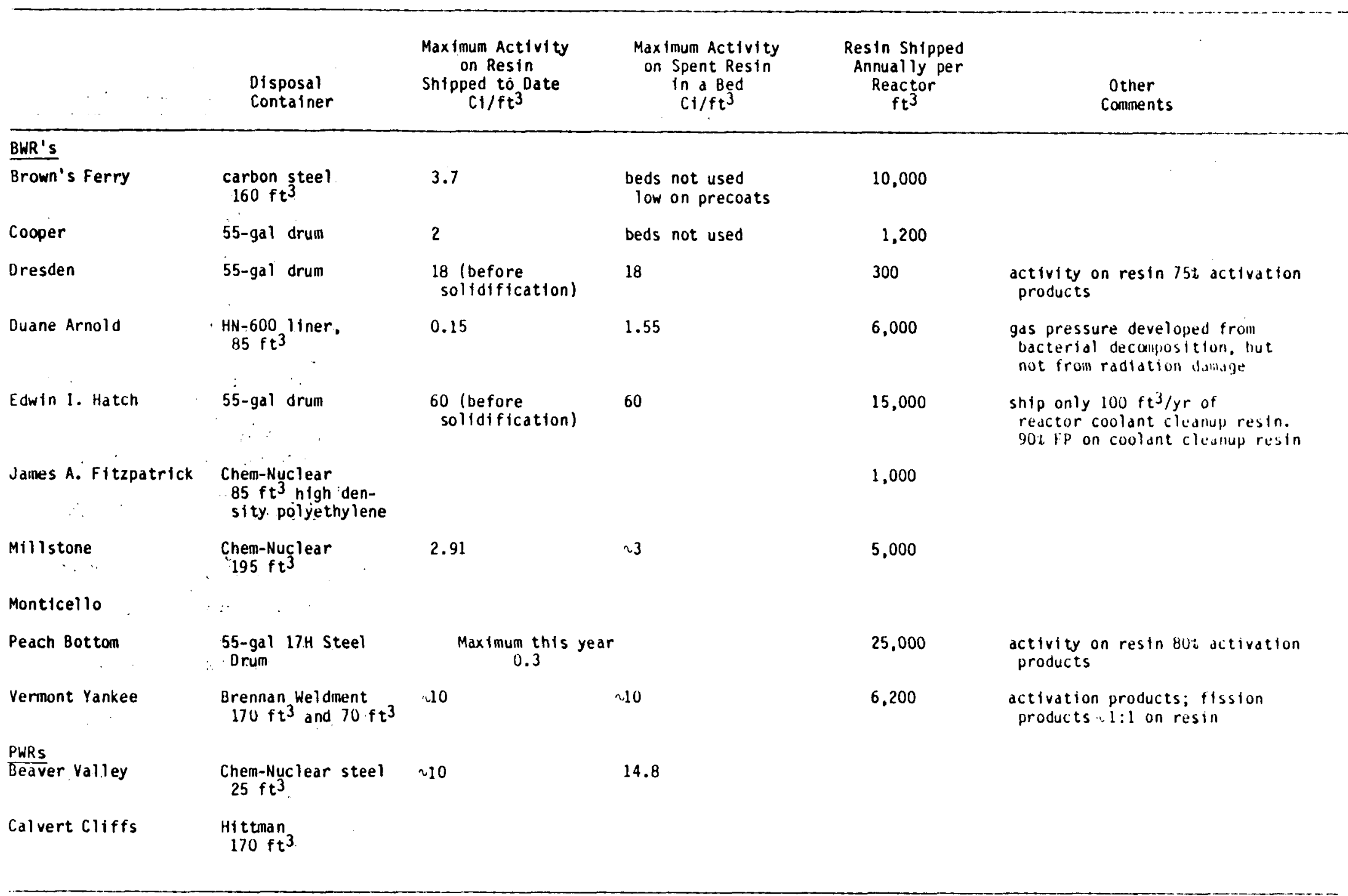


Table A.3, Continued

Summary of Pertinent Results From Survey of Organic Ion Exchange Resin Usage by LWRs

\begin{tabular}{|c|c|c|c|c|c|}
\hline & $\begin{array}{l}\text { Disposal } \\
\text { Contalner }\end{array}$ & $\begin{array}{l}\text { Maximum Activity } \\
\text { on Resin } \\
\text { Shipped to Date } \\
\mathrm{Cl} / \mathrm{ft}^{3}\end{array}$ & $\begin{array}{l}\text { Maximum Activity } \\
\text { on Spent Resin } \\
\text { in a Będ } \\
C 1 / \mathrm{ft}^{3}\end{array}$ & $\begin{array}{l}\text { Resin Shipped } \\
\text { Annually per } \\
\text { Reactfor } \\
\mathrm{ft}^{3}\end{array}$ & $\begin{array}{l}\text { Other } \\
\text { Comments }\end{array}$ \\
\hline Fort Calhoun & $\underset{126 \mathrm{ft}^{3}}{\text { CNSI }}$ & 2.7 & not answered & 100 & \\
\hline Donald C. Cook & $\begin{array}{l}H N-100, H N-200, \\
H N-600 \text { i i ners }\end{array}$ & 6.4 & 17 & 300 & $\begin{array}{l}\text { activity on resin } 808 \\
\text { activation products }\end{array}$ \\
\hline Joseph M. Farley & $\begin{array}{l}\text { H1ttman } \\
80,85,170 \mathrm{ft}^{3}\end{array}$ & 23 & 7 & 300 & \\
\hline Kewaunee & not answered & & & 150 & \\
\hline Maine Yankee & $\begin{array}{l}\text { Chem-Nuçlear Iiner } \\
126 \mathrm{ft}^{3}\end{array}$ & $2125^{a}$ & $\begin{array}{l}1500 \mathrm{R} / \mathrm{h} \text { (distance } \\
\text { not specifled) }\end{array}$ & 200 & $\begin{array}{l}\text { activity on resin mostiy } \\
\text { activation products }\end{array}$ \\
\hline Point Beach & $\begin{array}{l}\text { Chem-Nuc lear } \\
58 \& 85 \mathrm{ft}^{3}\end{array}$ & 33.1 & not much $>33$ & $500-1000$ & $\begin{array}{l}\text { maximum loading was unusually high: } \\
\text { activity on resin } 90 \% \text { activation } \\
\text { products }\end{array}$ \\
\hline Prairle Island & $\begin{array}{l}\text { H1ttman and } \\
\text { Chem-Nuclear } \\
80 \mathrm{ft}^{3}\end{array}$ & 1 & 2 & & \\
\hline St. Lucle & $\begin{array}{l}\text { Chem-Nuclear } \\
85: 200 \mathrm{ft}^{3}\end{array}$ & 26 & $\sim 6$ & 2850 & \\
\hline Trosan & $\begin{array}{l}\text { Nuclear Packaging } \\
50 \mathrm{ft}^{3}\end{array}$ & 5.4 & 5.4 & $\sim 350$ & $\begin{array}{l}\text { beta activity on resin } 80 s \\
\text { activiation products; alpha } \\
\text { activity on resin sometimes } \\
210 \mathrm{nCt} / \mathrm{g} \text {, but after solfification } \\
\text { always }<10 \mathrm{nCl} / \mathrm{g}\end{array}$ \\
\hline Yankee-Rowe & $\begin{array}{l}\text { carbon steel } \\
80 \mathrm{ft}^{3} \text { cyllinder }\end{array}$ & 3 & 20 & . $80-160$ & $\begin{array}{l}\text { activity on resin } 908 \text { fission } \\
\text { products }\end{array}$ \\
\hline $210 n$ & & $\begin{array}{l}30 \text { (before } \\
\text { solidification) }\end{array}$ & 40 & $5-10,000$ & $\begin{array}{l}\text { activity on resins mostly activation } \\
\text { products }\end{array}$ \\
\hline
\end{tabular}

Largely Co-58 (half-1ffe of 72 days). 
APPENDIX B

ANAL YT ICAL DATA SHEETS FOR

RADIONUCLIDE CONCENTRATIONS IN REACTOR COOLANT 
Table B.1

Data Sheet From Dresden Unit 3

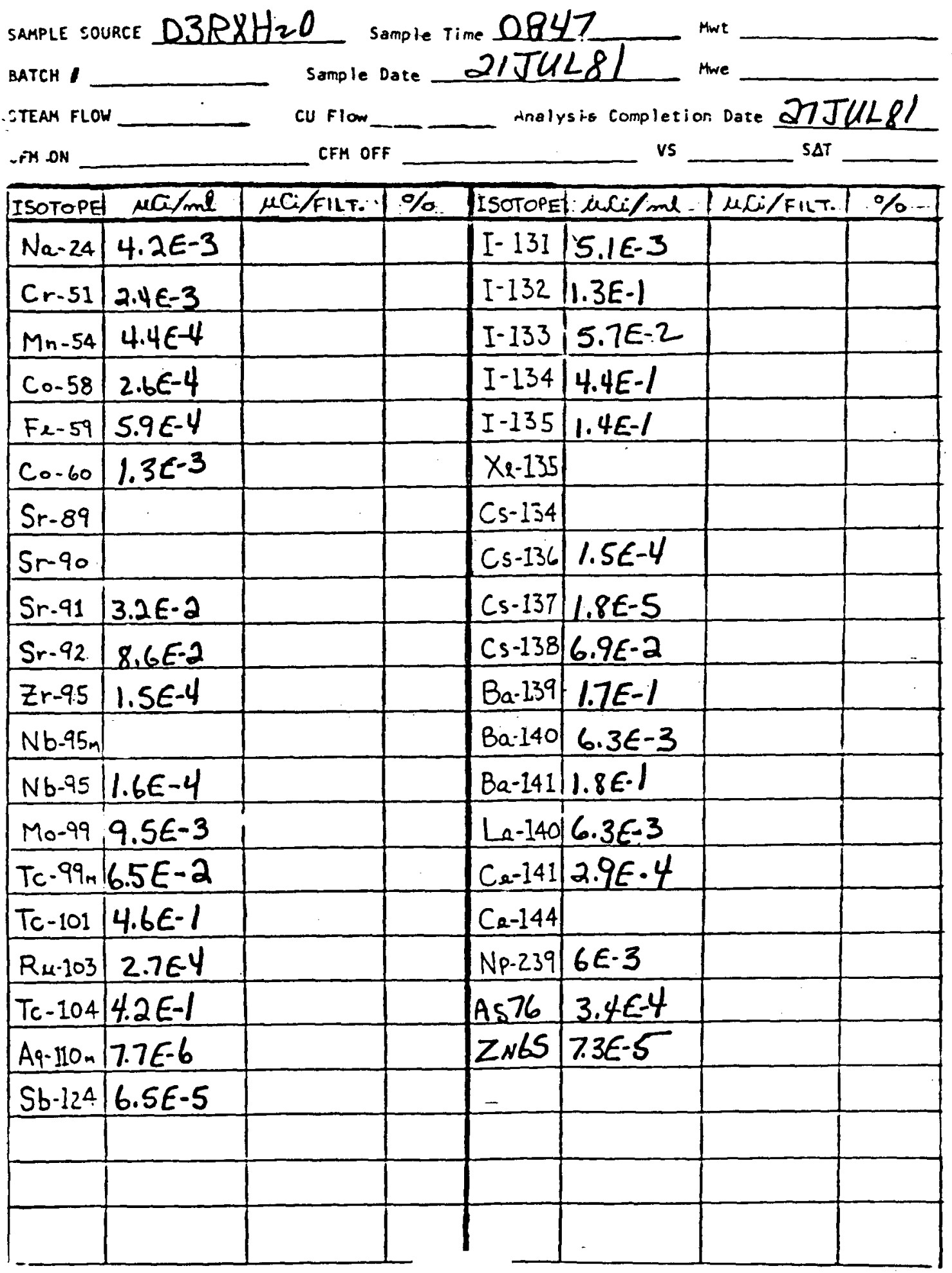


Table B.2

Data Supplied by St. Lucie

Copy of Addendum II to Table 31 of Clark's 1978 Report (2)

Adsondum I

: Ion excliange oyotcms - tadiunuclides pieseat

\begin{tabular}{|c|c|c|c|c|c|c|c|c|}
\hline \multirow{2}{*}{ Lotope } & \multicolumn{2}{|c|}{ Reactor coulent eyolem } & \multicolumn{2}{|c|}{ Botk acid iecrick } & \multicolumn{2}{|c|}{ Fuel pool } & \multicolumn{2}{|c|}{ Honte uyotsin } \\
\hline & Cunc. & Physlcal furm & Cunc: & Physical form & Cons. & Physisal form" & Conc: & Phycical fosm \\
\hline $\begin{array}{l}{ }_{H}^{H} \\
m_{0} B_{r} \\
i m_{X_{r}}\end{array}$ & $\begin{array}{l}1.47(-1) \\
6.40(-3) \\
2.05(-1)\end{array}$ & $\begin{array}{c}D G+L \\
D G+L \\
D G\end{array}$ & $\begin{array}{c}1.47(-1) \\
0 \\
0\end{array}$ & $D G+L$ & $\begin{array}{c}1.47(-1) \\
0 \\
0\end{array}$ & $D G+L$ & $\begin{array}{l}5.29(-3) \\
0 \\
0\end{array}$ & $D C+L$ \\
\hline$" k_{p}$ & $1.22(-1)$ & DG & $6.10(-2)$ & $\mathbf{D C}$ & $6.10(-2)$ & DC & 0 & \\
\hline$" K_{s}$ & $1.12(-1)$ & DG & 0 & & 0 & & 0 & \\
\hline${ }^{\infty} k_{i}$ & $3.59(-1)$ & DC & 0 & & 0 & & 0 & \\
\hline $\mathbf{O} \mathbf{R b}$ & $3.52(-1)$ & DS & 0 & & 0 & & $\begin{array}{l}0 \\
0\end{array}$ & \\
\hline$" R \mathbf{b}$ & $8.80(-3)$ & DS & $\therefore$ & & 0 & & $\begin{array}{c}0 \\
3.42(-8)\end{array}$ & DS \\
\hline 0 & $6.99(-4)$ & DS & $6.18(-6)$ & DS & $6.18(-6)$ & $\begin{array}{l}\text { DS } \\
\text { DS }\end{array}$ & $\begin{array}{l}3.42(-8) \\
3.44(-9)\end{array}$ & $\begin{array}{l}\text { DS } \\
\text { DS }\end{array}$ \\
\hline ms. & $3.60(-3)$ & DS & $3.60(-7)$ & DS & $3.60(-7)$ & DS & $3.44(-9)$ & DS \\
\hline my & $1.41(-4)$ & c & $1.36(-5)$ & $\mathbf{C}$ & $1.36(-5)$ & $\mathbf{c}$ & $3.87(-10)$ & $\mathbf{C}$ \\
\hline "st & $4.91(-4)$ & DS & 0 & & 0 & & 0 & \\
\hline "ny & $1.53(-2)$ & $c^{*}$ & $1.38(-2)$ & C & $1.38(-2)$ & C & $8.29(-7)$ & C \\
\hline Mo & $2.80(-1)$ & DS & $3.00(-2)$ & DS & $3.00(-2)$ & DS & $8.22(-7)$ & DS \\
\hline$" 103 \mathrm{Ru}$ & $5.70(-4)$ & C & $4.87(-5)$ & C & $4.87(-5)$ & c & $2.37(-8)$ & c \\
\hline Im Ru & $3.42(-5)$ & C & $3.36(-6)$ & C & $3.36(-6)$ & c & $4.03(-9)$ & c \\
\hline "I"To & $3.50(-3)$ & DS & 0 & & & & 0 & \\
\hline $\ln _{1}$ & $9.95(-9)$ & DS & 0 & & 0 & & 0 & \\
\hline "III & $5.48(-1)$ & DS & $2.52(-4)$ & DS & $2.52(-4)$ & DS & $5.74(-6)$ & DS \\
\hline III n' & $2.04(-1)$ & DG & $6.07(-2)$ & $D C$ & $6.07(-2)$ & DG & D & \\
\hline sot To & $4.55(-2)$ & DS & $6.92(-4)$ & DS & $6.92(-4)$ & DS & $1.7)(-7)$ & DS \\
\hline$m 1$ & $1.50(-1)$ & DS & 0 & & 0 & & 0 & \\
\hline$\omega_{1}$ & $7.81(-1)$ & DS & $6.25(-7)$ & DS & $6.25(-7)$ & DS & $1.43(-7)$ & DS \\
\hline$"{ }^{\prime \prime} x_{0}$ & $2.49(+1)$ & $\boldsymbol{D C}$ & $3.82(+1)$ & DC & $3.82(+1)$ & DG & 0 & \\
\hline${ }^{m} \mathrm{Te}$ & $3.06(-3)$ & DS & 0 & & 0 & & 0 & \\
\hline$\stackrel{|m|}{I}$ & $8.56(-2)$ & DS & 0 & & 0 & & 0 & \\
\hline${ }^{19} \mathrm{Cl}$ & $1.38(+2)$ & $D S+C$ & $1.37(-2)$ & $D S+C$ & $1.37(-2)$ & $\mathrm{DS}+\mathrm{C}$ & $1.84(-6)$ & DS+C \\
\hline "NI & $3.72(-1)$ & DS & $7.35(-14)$ & DS & $7.35(-14)$ & DS & 0 & \\
\hline $13 \times 10$ & $1.64(+1)$ & $D C$ & 0 & & 0 & & 0 & \\
\hline so & $3.50(-3)$ & DStC & $2.20(-3)$ & $D S+C$ & $2.20(-3)$ & DS+C & $5.82(-8)$ & DS+C \\
\hline${ }^{19} \mathrm{C}$ & $4.42(-2)$ & DE & $4.41(-2)$ & DSrC & $4.11(-2)$ & $D S+C$ & $6.67(-6)$ & DStC \\
\hline${ }^{10} \times$ & $4.97(-2)$ & $\mathbf{D C}$ & 0 & & 0 & & 0 & \\
\hline${ }^{24} \mathrm{C}$ & $9.52(-2)$ & - DS & 0 & & o & & 0 & \\
\hline $140 \mathrm{Bs}$ & $8.43(-4)$ & DS+C & $5.18(-6)$ & $D S+C$ & $5.18(-6)$ & $D S+C$ & $1.37(-8)$ & $D S+C=$ \\
\hline 100 & $8.07(-4)$ & C & $1.95(-6)$ & c & $1.95(-6)$ & C & $9.12(-10)$ & c \\
\hline${ }^{141} \mathrm{Pt}$. & $8.06(-4)$ & C & $5.11(-5)$ & c & $5.11(-5)$ & c & $1.39(-8)$ & c \\
\hline${ }^{140} \mathrm{Co}$ & $5.70(-4)$ & c & $5.57(-5)$ & C & $5.57(-5)$ & C & $6.31(-8)$ & C \\
\hline${ }^{\oplus} \mathbf{C o}_{0}$ & $7.16(-4)$ & $D S+C$ & $7.14(-5)$ & DS+C & $7.14(-5)$ & DS+C & $1.03(-7)$ & DS+C \\
\hline$m$ F。 & $294(-5)$ & $c$ & $256(-6)$ & C & $2.56(-6)$ & c & $1.33(-9)$ & $\underset{D S+C}{C}$ \\
\hline co & $6.40(-3)$ & DStC & $5.89(-4)$ & DS+C & $3.89(-4)$ & $\begin{array}{l}\text { DS+C } \\
\text { DS+C }\end{array}$ & $\begin{array}{l}3.91(-7) \\
4.30(-9)\end{array}$ & $\begin{array}{l}\text { DS+C } \\
\text { DS+C }\end{array}$ \\
\hline $\begin{array}{l}{ }^{4} \mathrm{Ma} \\
{ }^{\circ} \mathrm{Ca}\end{array}$ & $\begin{array}{l}3.79(-5) \\
5.20(-3)\end{array}$ & $\begin{array}{l}\text { DS+C } \\
\text { DS+C }\end{array}$ & $\begin{array}{l}3.72(-6) \\
4.19(-4)\end{array}$ & $\begin{array}{l}\text { DStC } \\
\text { DS+C }\end{array}$ & $\begin{array}{l}3.72(-6) \\
4.19(-4)\end{array}$ & $\begin{array}{l}\text { DStC } \\
\text { DS+C }\end{array}$ & $\begin{array}{l}4.30(-9) \\
1.65(-7)\end{array}$ & DS+C \\
\hline$\| z$ & $1.29(-6)$ & $c$ & $1.17(-7)$ & C & $1.17(-7)$ & c & 0 & \\
\hline
\end{tabular}

-Values listed at nCV/ce; numbers in () are powers of 10. Dals are expreaced for 0.1\% failed fuet.

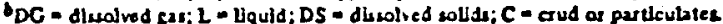


Table B. 3

Data Sheet From Donald C. Cook Unit 1

LIST OF RADIONUCLIDES

SPENT FUEL PIT

CS -134
CS -137
Co -58
Co -60

$3.590 E-4$

$1.234 \mathrm{E}-3$

$1.184 E-3$

$3.975 E-3$

$\mu \mathrm{Cj} / \mathrm{m}]$

$\mu \mathrm{Ci} / \mathrm{ml}$

${ }_{\mu} \mathrm{Ci} / \mathrm{mT}$

${ }_{\mu} \mathrm{Ci} / \mathrm{ml}$

U- 1 REACTOR COOLANT CRUD

$\begin{array}{llll}I-131 & 9.061 & E-5 & \mu \mathrm{Ci} / \mathrm{CC} \\ \mathrm{Cr}-51 & 8.781 \mathrm{E}-5 & \mu \mathrm{Ci} / \mathrm{CC} \\ \mathrm{I}-133 & 7.951 \mathrm{E}-5 & \mu \mathrm{Ci} / \mathrm{CC} \\ \mathrm{Cs}-134 & 1.297 \mathrm{E}-5 & \mu \mathrm{Ci} / \mathrm{CC} \\ \mathrm{Ag}-110 \mathrm{~m} & 4.589 \mathrm{E}-5 & \mu \mathrm{Cj} / \mathrm{CC} \\ \mathrm{Zr}-95 & 1.398 \mathrm{E}-5 & \mu \mathrm{Ci} / \mathrm{CC} \\ \mathrm{Nb}-95 & 2.759 \mathrm{E}-5 & \mu \mathrm{Ci} / \mathrm{CC} \\ \mathrm{Co}-58 & 2.466 \mathrm{E}-4 & \mu \mathrm{Cj} / \mathrm{CC} \\ \mathrm{Mn}-54 & 1.695 \mathrm{E}-5 & \mu \mathrm{Ci} / \mathrm{CC} \\ \mathrm{CO}-60 & 6.940 \mathrm{E}-5 & \mu \mathrm{Ci} / \mathrm{CC}\end{array}$

U-1 REACTOR COOLANT

I - 131

$\mathrm{Xe}-133$

$8.170 \mathrm{E}-3$

$1.564 \mathrm{E}-1$

$k r-85 m$

$8.013 \mathrm{E}-3$

$\mathrm{Kr}-88$

$5.068 \mathrm{E}-3$

$X e-133 m$

$6.299 \mathrm{E}-3$

$X e-135$

$6.486 \mathrm{E}-2$

$\mathrm{Kr}-87$

4.979 E-3

Cs -138

$3.603 \mathrm{E}-2$

$3.926 \mathrm{E}-3$

$1.978 \mathrm{E}-3$

$M n-54$

$3.820 \mathrm{E}-3$

$Y-88$

1.527 E-2

$\mathrm{Rb}-88$

3. $348 \mathrm{E}-3$

$\mathrm{Rb}-89$

Ar -41

$1.895 \mathrm{E}-3$

$\mathrm{Na}-24$

$8.929 E-3$

$\left.{ }_{\mu} \mathrm{Ci} / \mathrm{m}\right]$

${ }_{\mu} \mathrm{Ci} / \mathrm{ml}$

${ }_{\mu} \mathrm{Ci} / \mathrm{ml}$

$\left.{ }_{\mu} \mathrm{Cj} / \mathrm{m}\right]$

${ }_{\mu} \mathrm{Cj} / \mathrm{ml}$

$\mu \mathrm{Ci} / \mathrm{ml}$

${ }_{\mu} \mathrm{Ci} / \mathrm{ml}$

$\mu \mathrm{Ci} / \mathrm{ml}$

${ }_{\mu} \mathrm{Ci} / \mathrm{ml}$

$\mu \mathrm{C} i / \mathrm{ml}$

${ }_{\mu} \mathrm{Ci} / \mathrm{m} 1$

${ }_{\mu} \mathrm{Ci} / \mathrm{ml}$

${ }_{\mu} \mathrm{Ci} / \mathrm{ml}$

${ }_{\mu} \mathrm{Ci} / \mathrm{ml}$

${ }_{\mu} \mathrm{Cj} / \mathrm{m} 1$

U-1 Primary Water Storage Tank

No Activity Detected

Steam Generator Blowdown Flash Tank No Activity Detected 
Table B.4

Data Sheet From Fort Calhoun

FORT CALHOUN BTATION (OPPD)

$17-A U B-81 \quad 10120828$

RADIONUCLIDEANALYBIB REPORT

NUCLIDE

ACTIUITY IN UC/BH

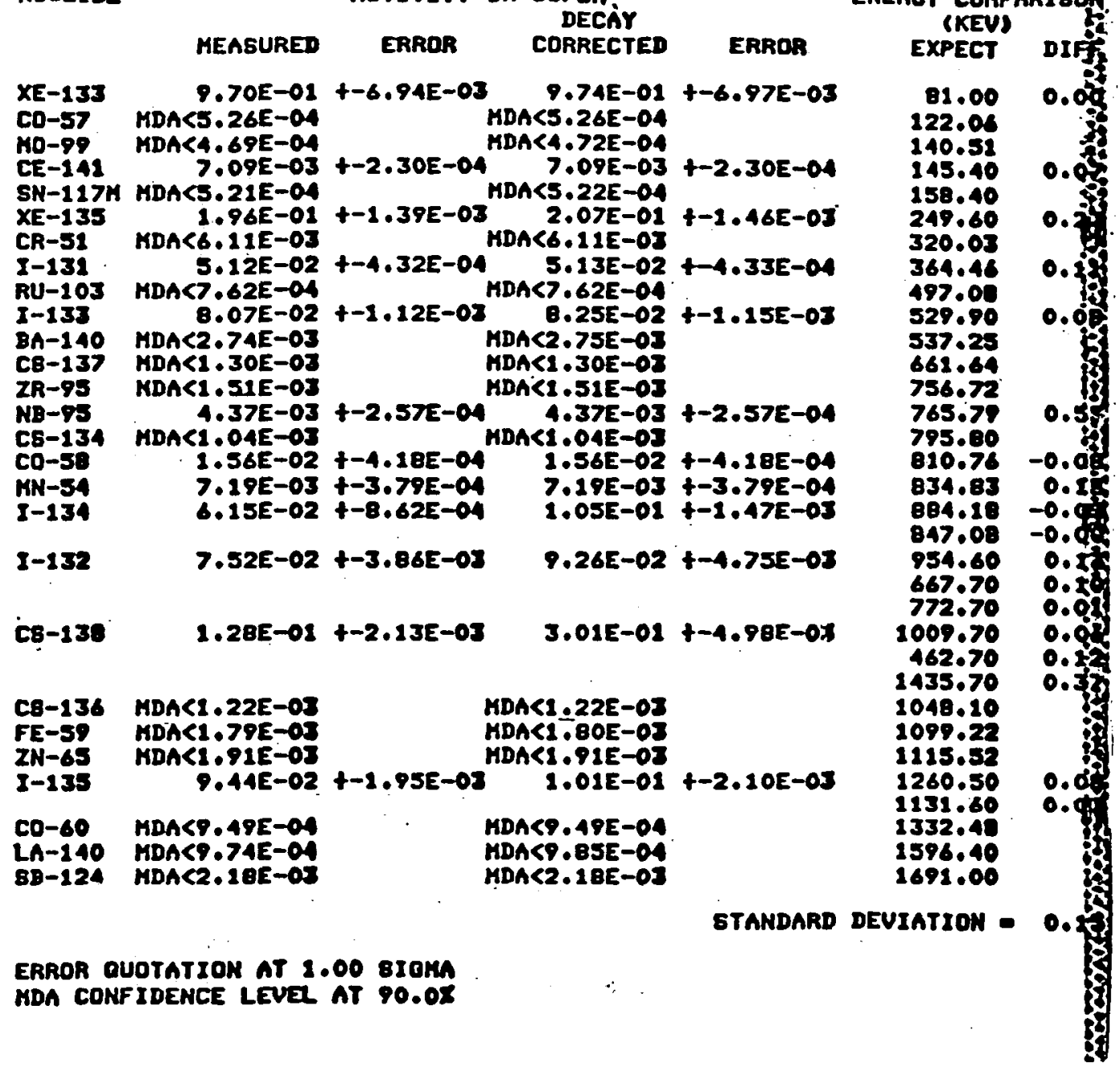

ENEROY COKPARIBOH 
Table B.5

Data Sheet From Point Beach. Unit 1

UNIT I REACTOR CUOLANT EBAR CALCULATION

fLl AYERAGE AND TOTAL ENERGIES LISTED AS MEY *

\begin{tabular}{|c|c|c|c|c|c|c|}
\hline ISDTOPE & BETR & GAMMA & CE & EI & AI ruci/cos & EIRI \\
\hline $\begin{array}{l}1-131 \\
1-132 \\
I-135 \\
1-134 \\
I-135\end{array}$ & $\begin{array}{l}0.1970 \\
0.4480 \\
0.4230 \\
0.4550 \\
0.3080\end{array}$ & $\begin{array}{l}0.3710 \\
2.4000 \\
0.4770 \\
1.9400 \\
1.7800\end{array}$ & $\begin{array}{l}0.0000 \\
0.0000 \\
0.0000 \\
0.0000 \\
0.0000\end{array}$ & $\begin{array}{l}0.5680 \\
2.8480 \\
0.9000 \\
2.3950 \\
2.0880\end{array}$ & $\begin{array}{l}3.10000000 E-02 \\
2.11000000 E-01 \\
2.01000000 E-01 \\
4.54000000 E-01 \\
2.66000000 E-01\end{array}$ & $\begin{array}{l}0.0176 \\
0.6009 \\
0.1809 \\
1.0873 \\
0.5554\end{array}$ \\
\hline $\begin{array}{l}\text { XE-133 } \\
K R 85 H \\
\text { XE133H } \\
K R-88 \\
X E-135 \\
K R-87 \\
\text { AR-41 } \\
K R-85 \\
X E 1351 \\
X 1138\end{array}$ & $\begin{array}{l}0.1150 \\
0.2330 \\
0.0000 \\
0.3410 \\
0.3220 \\
1.0500 \\
0.4040 \\
0.2230 \\
0.0000 \\
0.8000\end{array}$ & $\begin{array}{l}0.0300 \\
0.1510 \\
0.0325 \\
1.7400 \\
0.2460 \\
1.3700 \\
1.2770 \\
0.0021 \\
0.4220 \\
2.8700\end{array}$ & $\begin{array}{l}0.0280 \\
0.0000 \\
0.2100 \\
0.0000 \\
0.0000 \\
0.0000 \\
0.0000 \\
0.0000 \\
0.0974 \\
0.0000\end{array}$ & $\begin{array}{l}0.1730 \\
0.3840 \\
0.2425 \\
2.0810 \\
0.5680 \\
2.4200 \\
1.6810 \\
0.2251 \\
0.5194 \\
3.6700\end{array}$ & $\begin{array}{l}1.34000000 E-01 \\
9.22000000 E-02 \\
1.71000000 E-04 \\
1.52000000 E-01 \\
3.29000000 E-01 \\
5.26000000 E-02 \\
8.83000000 E-03 \\
6.09000000 E-03 \\
9.26000000 E-02 \\
1.37000000 E-01\end{array}$ & $\begin{array}{l}0.0232 \\
0.0354 \\
0.0000 \\
0.3163 \\
0.1869 \\
0.1273 \\
0.0148 \\
0.0014 \\
0.0481 \\
0.5028\end{array}$ \\
\hline 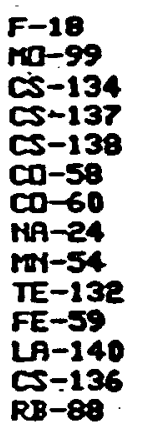 & $\begin{array}{l}0.2120 \\
0.3800 \\
0.1660 \\
0.1730 \\
1.1300 \\
0.0237 \\
0.1050 \\
0.4630 \\
0.0002 \\
0.1000 \\
0.1260 \\
0.3970 \\
0.11390 \\
1.6100\end{array}$ & $\begin{array}{l}0.9910 \\
0.1370 \\
1.5900 \\
0.5630 \\
2.0800 \\
0.9770 \\
2.5100 \\
4.1230 \\
0.8350 \\
0.2160 \\
1.4900 \\
2.1200 \\
2.2300 \\
0.5700\end{array}$ & $\begin{array}{l}0.0000 \\
0.0000 \\
0.0000 \\
0.0730 \\
0.0000 \\
0.0000 \\
0.0000 \\
0.0000 \\
0.0000 \\
0.0477 \\
0.0000 \\
0.0000 \\
0.0000 \\
0.0000\end{array}$ & $\begin{array}{l}1.2030 \\
0.5170 \\
1.7560 \\
0.8090 \\
3.2100 \\
1.0007 \\
2.6150 \\
4.5860 \\
0.8352 \\
0.3637 \\
1.3160 \\
2.5170 \\
2.3690 \\
2.1800\end{array}$ & $\begin{array}{l}6.94000000 E-00 \\
1.96000000 E=05 \\
1.36000000 E-05 \\
2.81000000 E-05 \\
2.78000000 E-01 \\
9.58000000 E-05 \\
2.13000000 E-05 \\
7.49000000 E-05 \\
3.10000000 E-05 \\
8.74000000 E-04 \\
3.04000000 E-06 \\
1.58000000 E-04 \\
1.16000000 E-04 \\
2.17000000 E-01\end{array}$ & $\begin{array}{l}0.0835 \\
0.0010 \\
0.0024 \\
0.0023 \\
0.8924 \\
0.0001 \\
0.0001 \\
0.0343 \\
0.0000 \\
0.0003 \\
0.0000 \\
0.0004 \\
0.0003 \\
0.4731\end{array}$ \\
\hline
\end{tabular}

TOTAL GAS COMCENTRATION CUCI COS
TOTAL MCA LIOUID CONCENTRATION CUCTCCO $1.00449100 E+00$
$1.74229124 E+00$

$\begin{array}{ll}\text { ICN IS MINUTE DECFY, CUCINCO } & 2.0791 \\ \text { RATID MCA LIO. ACT. ICN RCT. } & 0.8380\end{array}$

TOTAL EBAR: (SUM EIAI) CGAS.ACT.+ MCA LIQ.RCT. EXC. IODIMES) = 1.7340

TECH SPEC CDOLANT ACTIVITY LIMIT: (1 00/EBAR) (CI/M3) = 57.6696

FERCENT OF TECH SPEC RLLOWANCE PRESENTLY CIMCL. IDDIMESO: 4.7630 
APPENDIX C

ANAL YT ICAL DATA SHEETS FOR RADIONUCL IDE LOADINGS ON SPENT RESIN FROM REACTOR COOLANT CLEANUP 
Table C.1

Data Sheet From Donald C. Cook Unit 1

ISS WEIGHTER OECAY TIME TO HE USELS HU -SAMSLE IIATE 21.6 91

IS 21 JUN, 1981 CORREC. ? YES

SAMFLE TIME 0928

DATE ANALYZED 21 S. 81

IS 21 JUN, 1981 COKFECT ? YES

TIME ANALYZED 1123

I.ECAY TIME: $115.00 \mathrm{MIN}$

REGION: 1

GEOHETRY: 10

KEV WIMNOW: 2

* OF SIGMA UNITS:- 2

* OF SMOOTHS: 1

IIEAD TIME ( $Z$ ): 5

ANALYZ MULTIPLETS?

SAHPLE ID+CONFIG: SPENT-RESIN TANK $\$ 6453-R$ -

SAMPLED BY: BS

ANALYZED BY: ERS

RX POWER (RCS SAMPLES DNLY): NA

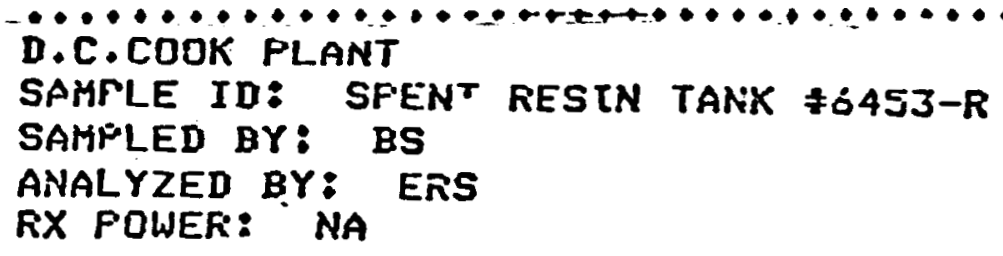

COLLECT TIME:

1000. (SEC)

\section{RADIONUCL IDE aNALYSIS}

ISOTOFE

C0 -.57

I-1 $3:$

CS -134

$S E-124$

CS -137

NE -95

CO-53

$M A 2-54$

Co-so
ACTIUITY

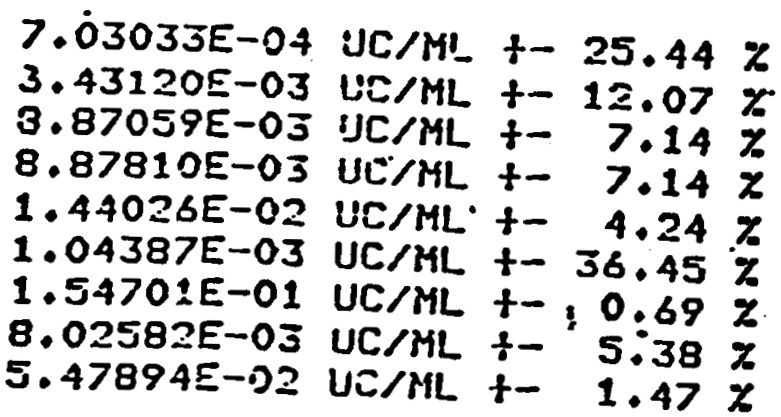


Table C.2

Loading Calculation From Donald C. Cook Unit 1

DEIIY - TALTER RESIN CALCULATIOH SHEET

\begin{tabular}{|c|c|c|c|c|c|}
\hline I sotope & $\begin{array}{l}\text { Concentration } \\
\text { from Lab }\end{array}$ & $\begin{array}{c}\text { (a) } \\
\text { Fraction } \\
\text { of Total } \\
\text { Concentration }\end{array}$ & $\begin{array}{l}\text { (b) } \\
\tau / 10\end{array}$ & $\begin{array}{c}\text { (c) } \\
\text { Exposure } \\
\text { Contribution } \\
(\mathrm{a}) \times(\mathrm{b})\end{array}$ & $\begin{array}{l}\text { Total } \\
\text { Activit } \\
\text { in Pesio } \\
\text { (a) } x \text { (e) }\end{array}$ \\
\hline$M N-54$ & $8.026 \times 10^{-3}$ & .0332 & 0.47 & .0156 & $13.766^{\circ}$ \\
\hline $\mathrm{CO}_{-57}$ & $7.030 \times 10^{-4}$ & .0029 & 0.09 & .000261 & $1.202-$ \\
\hline $\mathrm{CO}-58$ & $1.547 \times 10^{-1}$ & .6396 & 0.55 & .35178 & 265.200 \\
\hline $\mathrm{CO}-60$ & $5.479 \times 10^{-2}$ & .2265 & 1.32 & .29898 & 93.917 \\
\hline$A_{9-110 a}$ & & & 1.43 & & \\
\hline 1.131 & $3.431 \times 10^{-3}$ & .0142 & 0.22 & .003124 & 5.5980 \\
\hline Cs-134 & $8.871 \times 10^{-3}$ & .0367 & 0.87 & .031929 & 15.217 \\
\hline$c s-137$ & $1.440 \times 0^{-3}$ & .0059 & 0.33 & .001947 & 2.426 \\
\hline La-1 $\leq 0$ & & & 2.37 & & \\
\hline$z_{r-05}$ & & & 0.41 & & \\
\hline Nb-55 & $1.0 \% 96 \times 0^{-3}$ & $.00 \times 3$ & 0.42 & .001500 & 1.783 \\
\hline $5 b-124$ & $8.878 \times 0^{-3}$ & .0367 & 0.98 & .035966 & 15.217 \\
\hline TOTAL & $2.4188 \times 10^{-1}$ & 1.00 & $\sim$ & .741393 & 414.043 \\
\hline
\end{tabular}

Exposure Contribution (c) - Frection of total concentration (a) $\times$ s/no (b):

Exposure at 1 meter from $100 \mathrm{ml}$ sample $=\cdots .0167 \mathrm{R} / \mathrm{hr}$.

if reading tiken at $3 \mathrm{ft} ., \mathrm{R} / \mathrm{hr}$ at $\mathrm{I}$ meter $=\mathrm{R} / \mathrm{hr}$ at $3 \mathrm{ft} . \times .836$

.020

$\times .836$

(B) Resin voluze fector $=\mathrm{ft}^{3}$ in cask $\times \quad i 93.2$

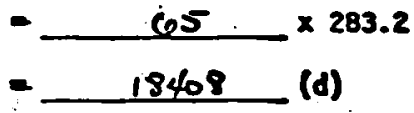

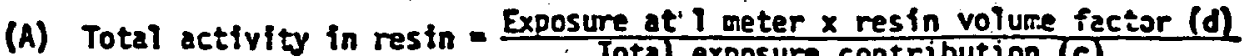
Total exposure contribution (c)

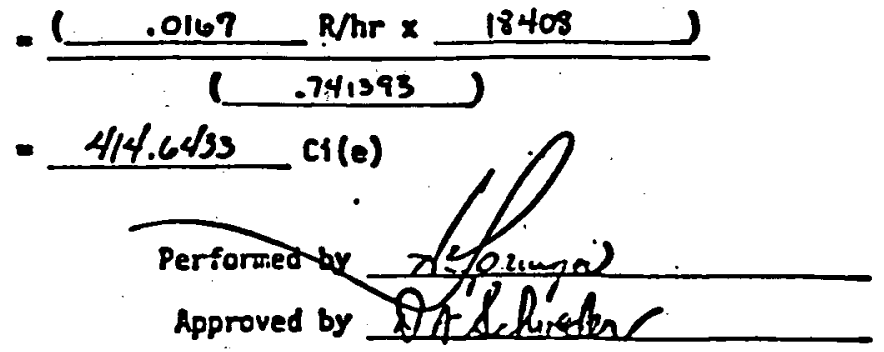


Table C.3

Data Sheet From E. I. Hatch Unit 1

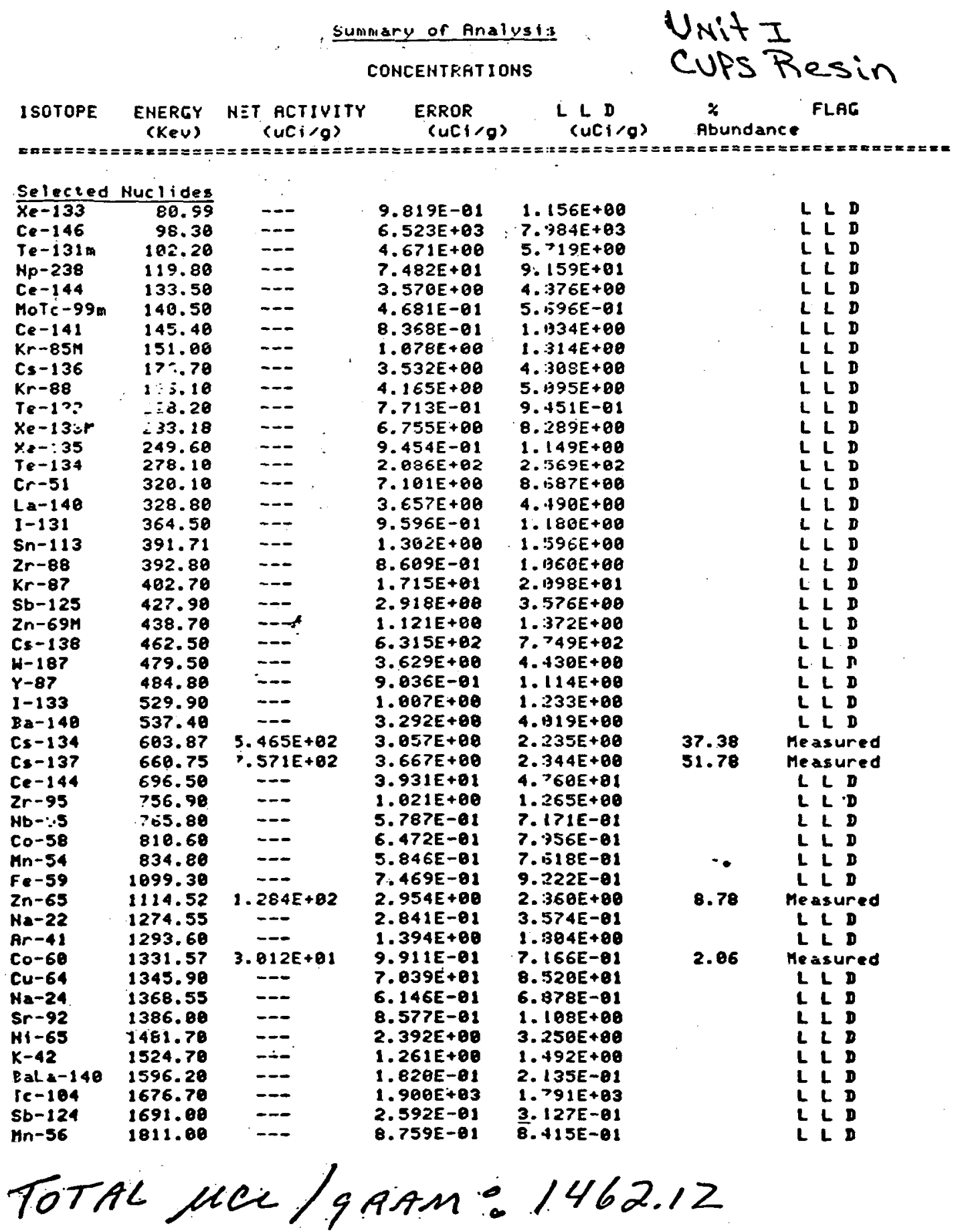


Table C.4

Data Sheet From Maine Yankee

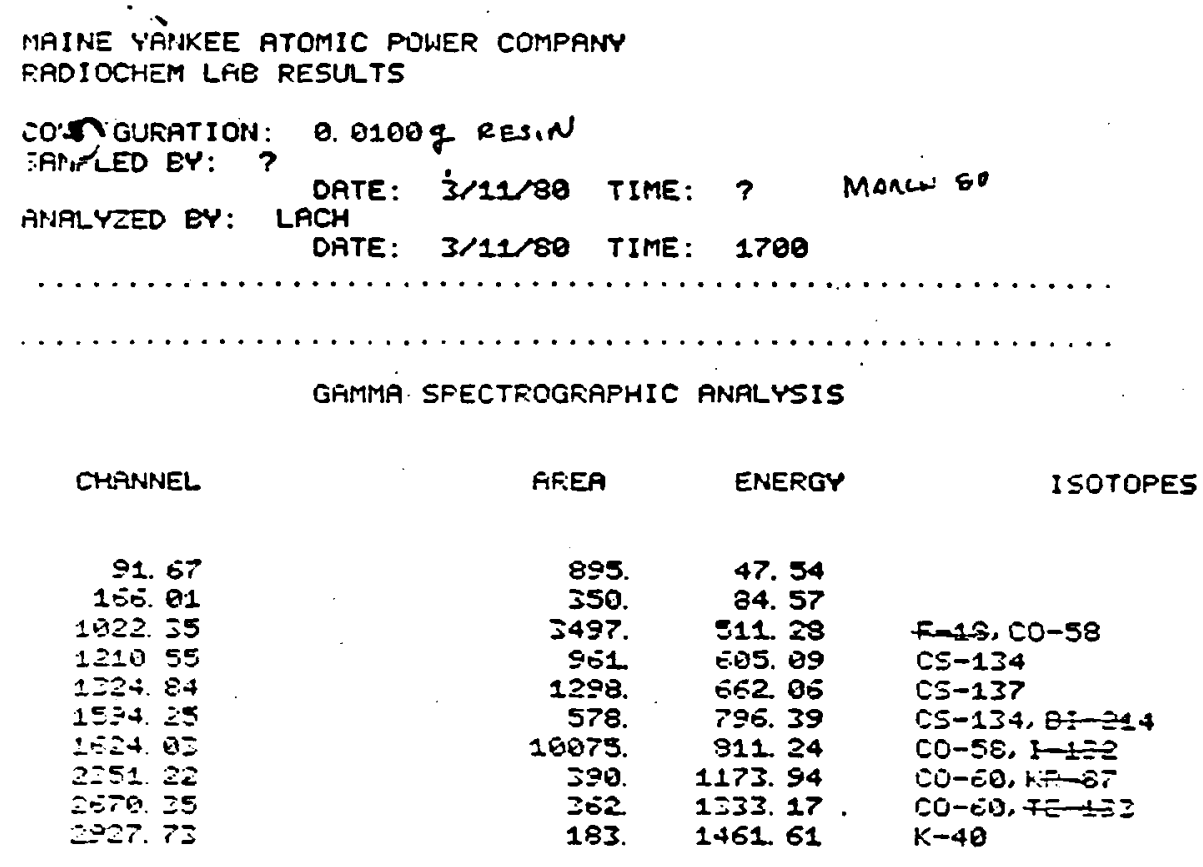

FAOIOHLICL IOE FHALYSIS

ISOTOPE ACTIVITY

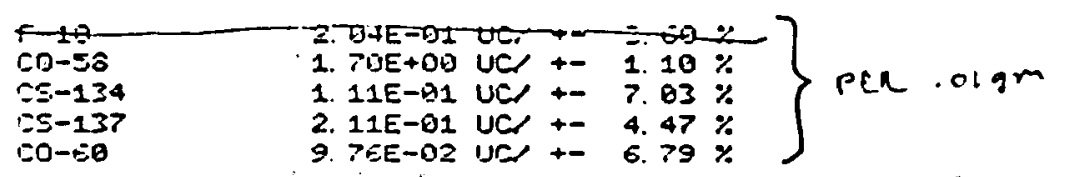

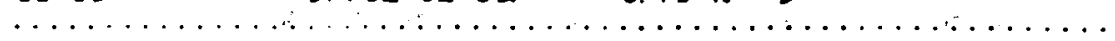

\begin{tabular}{|c|c|c|c|}
\hline ISOTOPE & THEOFET ICAL & MEASURED & DIFFERENCE \\
\hline $\begin{array}{l}F-18 \\
20-58 \\
C 5-1 \geq 4 \\
C 5-137 \\
C 0-09\end{array}$ & 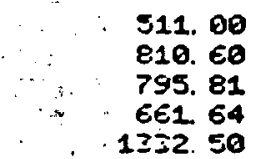 & $\begin{array}{r}511.28 \\
81124 \\
796.39 \\
662.66 \\
1333.17\end{array}$ & $\begin{array}{l}0.28 \\
0.64 \\
0.58 \\
0.42 \\
0.67\end{array}$ \\
\hline
\end{tabular}

STRIT.AFO CEVIATION= . 9. 54 ..

FESULTS FEYYIEHED EY

$+$

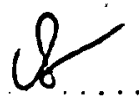


Table C.5

Data Sheet From Peach Bottom

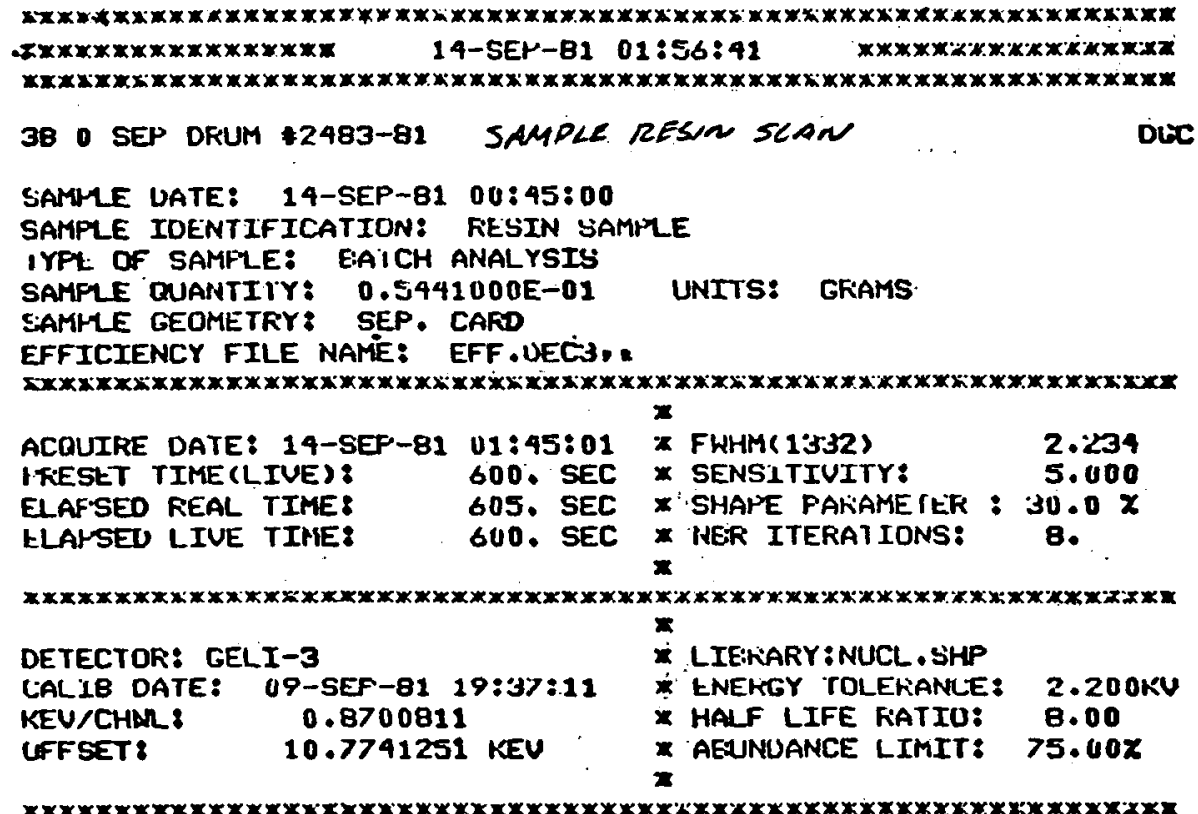

$>$ RUN PB.REPORT

IDENTIFIED FEAK KEFORT:

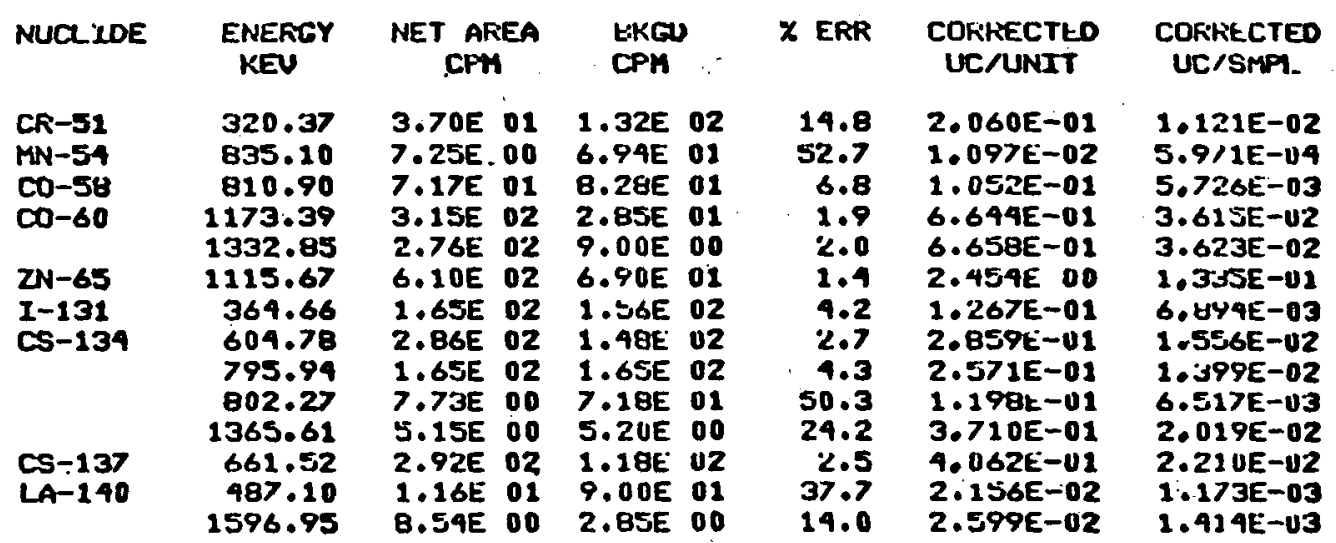


Table C.6

Data Sheet for Resin Shipment, Peach Bottom

RESIN SHIFMENT REFORT SUMMARY:

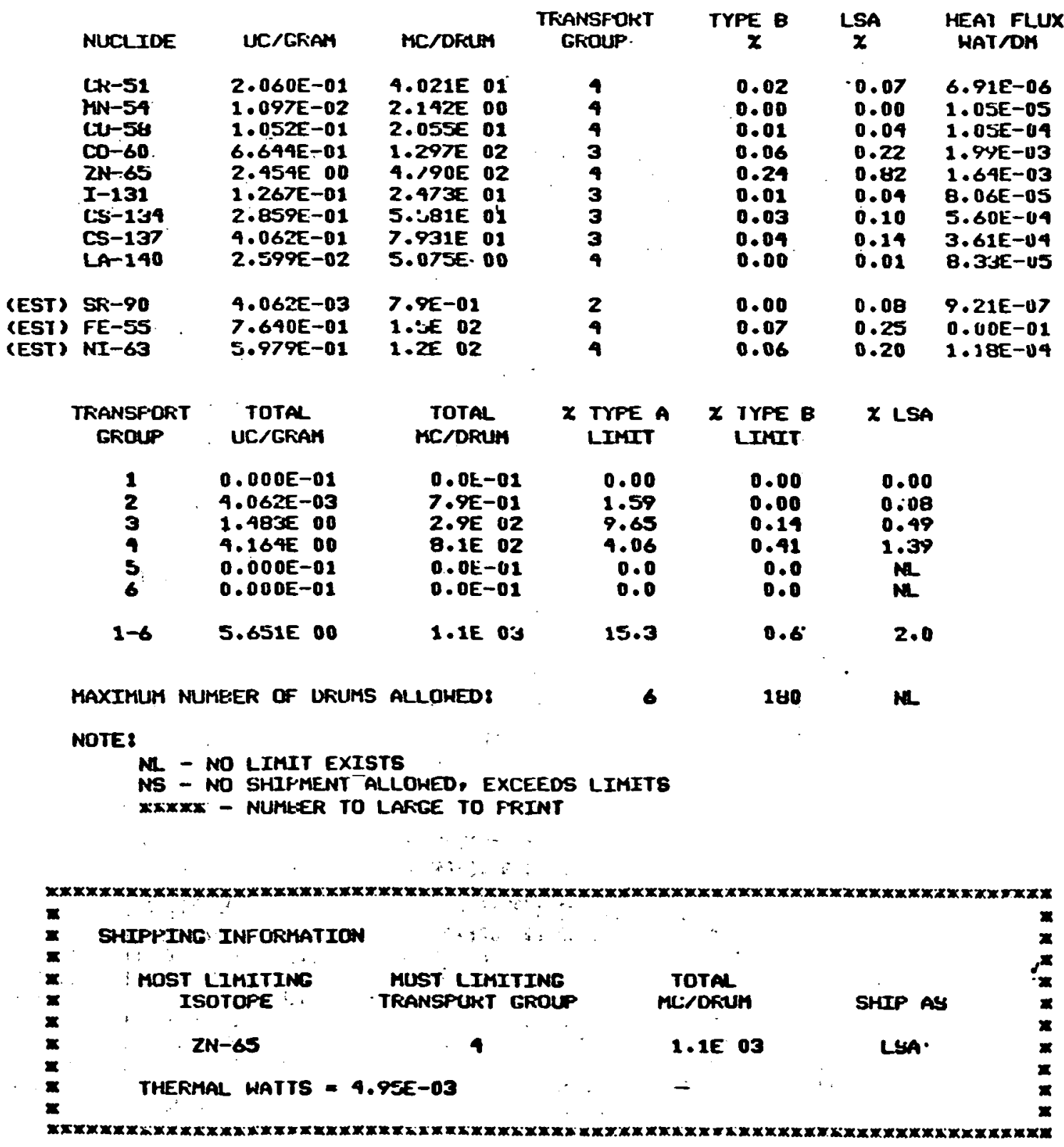




\author{
Table C. 7 \\ Data Sheet From Trojan
}

June 12. 1981

P. O. 19425

GAMAA EMITTING NUCLIDES

The xxxx number indicates the sample number we have designated that particular sample for our records. The results of the game activity on the two filters (9363F) are expressed in terms of total microcuries. The results of the gamma activity on the resin (9363R) are expressed in terme of ricrocuries per gram. The weight of the resin is 2.10E-01 grams. Results are decay corrected to $5 / 14 / 81$ at 1200 hours.

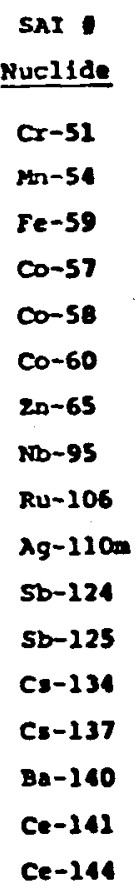

93638
yci/total
$<2.22(-3)$
$4.64 \pm .16(-2)$
$<1.37(-3)$
$1.66 \pm .29(-3)$
$2.38 \pm .23(-2)$
$6.04 \pm .06(-1)$
$7.44 \pm 2.50(-3)$
$5.15 \pm .92(-3)$
$<5.00(-3)$
$3.38 \pm .88(-3)$
$<7.52(-4)$
$2.08 \pm .16(-2)$
$2.52 \pm .09(-2)$
$6.76 \pm .18(-2)$
$9.80 \pm 3.7(-4)$
$<1.02(-4)$
$3.27 \pm .20(-2)$

$9363 R$
$\mu C 1 / g r a$
$<1.21(-2)$
$2.78 \pm .10(0)$
$<5.87(-2)$
$6.07 \pm 2.4(-2)$
$5.324 .87(-2)$
$4.57 \pm .09(1)$
$<6.71(-2)$
$<2.26(-2)$
$<1.95(-1)$
$<4.04(-2)$
$<1.78(-2)$
$<1.65(-1)$
$5.13 \pm .17(0)$
$1.264 .01(1)$
-2
$<1.32(-2)$
$3.49 \pm 1.9(-2)$


Table C.8

Data Sheet From Vermont Yankee

1. Total Volume of Resin shipped (1980) - $6200 \mathrm{cu}$ ft.

2. Isotopic from Low Level shipment (Condensate Demins/Radwaste) Cs-134 7.02E-1 $\mu \mathrm{C} 1 / \mathrm{gm}$

Cs-137 2.27E+0 $\mu \mathrm{CI} / \mathrm{gm}$

Co-58 7.40E-2 $\mu \mathrm{C} 1 / \mathrm{gm}$

$\mathrm{Mn}-54 \quad 1.28 \mathrm{E}-1 \mu \mathrm{C} 1 / \mathrm{gm}$

2n-65 4.61E-1 $\mu \mathrm{Cl} / \mathrm{gm}$

Co-60 9.24E-1 $\mu \mathrm{Ci} / \mathrm{gm}$

Total Activity - $8780 \mathrm{mCl}$

3. Isotopic from High level shipment (Reactor Cleanups)

Tc-99m 4.19E-1 $\mu \mathrm{CI} / \mathrm{gm}$

I-131 5.35E-1 $\mu \mathrm{CI} / \mathrm{gm}$

Cs-134 1.78E+1 $\mu \mathrm{Cl} / \mathrm{gm}$

Cs-137 4.84E+1 $\mu \mathrm{CI} / \mathrm{gm}$

$\mathrm{Zr}-95 \quad 1.11 \mathrm{E}+1 \mu \mathrm{Cl} / \mathrm{gm}$

Co-58 $5.88 \mathrm{E}+0 \mu \mathrm{Cl} / \mathrm{gm}$

Mn-54 5.98E+0 $\mu \mathrm{C} 1 / \mathrm{gm}$

Zn-65 2.03E+1 $\mu \mathrm{C} 1 / \mathrm{gm}$

Co-60 3.05E+1 $4 \mathrm{Cl} / \mathrm{gm}$

Total Activity - 127.6 Curies 


\section{APPENDIX D}

ANAL YT ICAL DATA SHEET FOR LOADING OF TRANSURANIC NUCLIDES ON SPENT- REACTOR COOLANT CLEANUP RESIN 
Table D.1

Data Sheet From Trojan

June 12, 1981

P. O. 19425

ALPHA NUCLIDES

Results of $9363 \mathrm{~F}$ are expressed in terms of microcuries per sapple. Results of $9363 R$ are expressed in terms of microcuries per gram. Activity is decay corrected to 4-01-81, at 1200 hours.

\section{Results}

\section{SAI}

Nuclides

$239.240 \mathrm{Pu}$

${ }^{238} \mathrm{Pu}$

${ }^{241} \mathrm{Am}$

$242.243 \mathrm{~cm}$

$244 \mathrm{~cm}$
$9363 F$

Conc. (HCI total)

$1.32 \pm .09(-3)$

$5.84 \pm .41(-4)$

$1.51 \pm .21(-5)$

$5.12 \pm .44(-5)$

$3.94 \pm 1.07(-6)$
$9363 R$

Conc. (LC1/arar)

$1.14 \pm .06(-2)$

$2.96 \pm .25(-3)$

$5.97 \pm .99(-5)$

$7.32 \pm 1.2(-5)$

5. $77 \pm 3.08(-6)$ 


\section{APPENDIX E \\ COMPUTER PROGRAM FOR CALCULATING DOSE DELIVERED TO \\ ORGANIC ION EXCHANGE RESIN BEDS BY DIFFERENT RADIONUCLIDE LOADINGS}

The program was written for interactive use in INTERCOM subsystem of the CDC 6600-15 computer at Brookhaven National Laboratory.

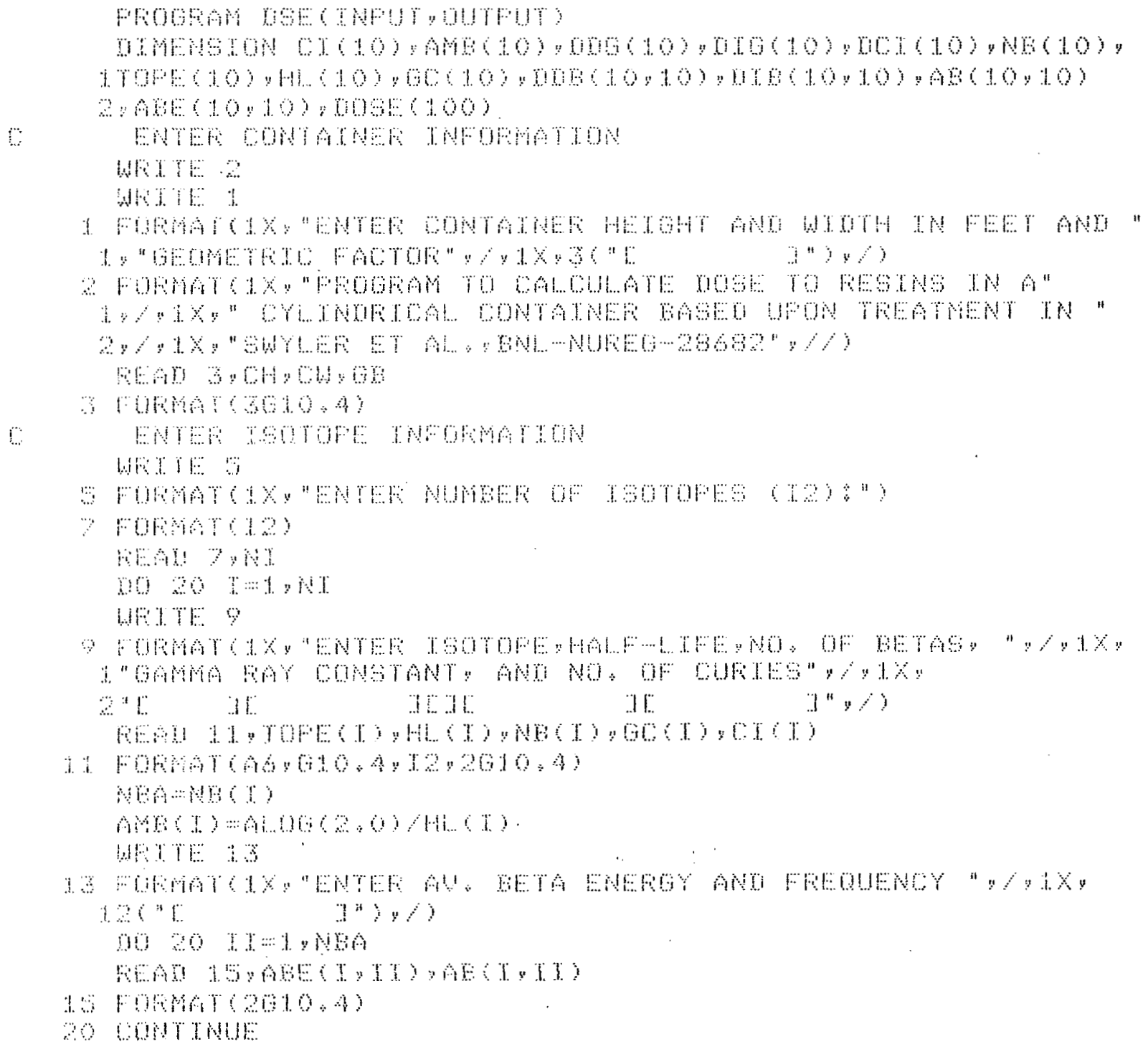




\section{APPENDIX E, Continued \\ COMPUTER PROGRAM FOR CALCULATING DOSE DELIVERED TO
ORGANIC ION EXCHANGE RESIN BEDS BY DIFFERENT RADIONUCLIDE LOADINGS}

$\cdots$

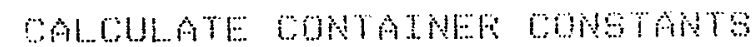

$\because \cdots, \ldots+0)$

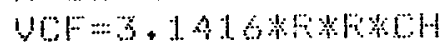

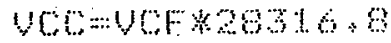

C BETA MOSF LACOUATIOH

[io 200 , I : $: \mathrm{Al}$

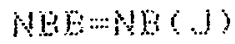

mo 100 Ka:

and (.)

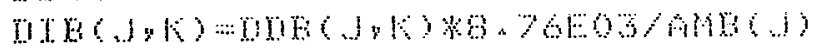

1.

100 COTTINUE:

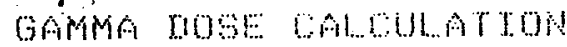

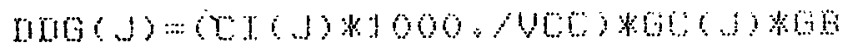

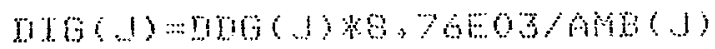

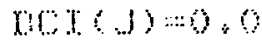

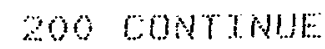

6

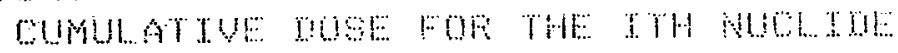

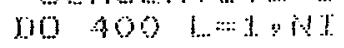

1.6.

aO 300 Ma.

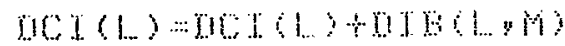

300 oONT THUE:

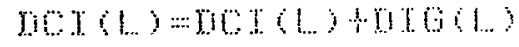

C.

400 CONTTHUE:

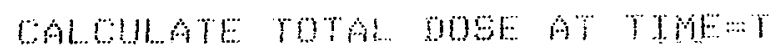

\section{AFITE 420}

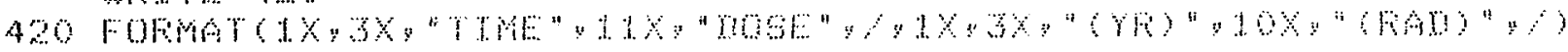

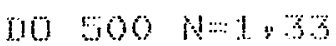

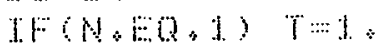

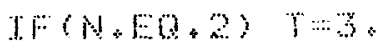

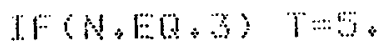

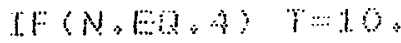

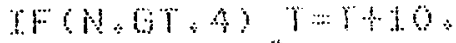

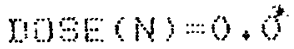

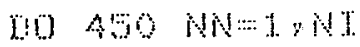

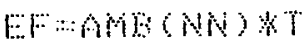

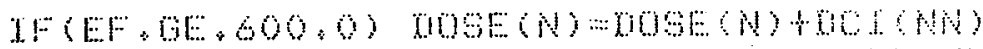

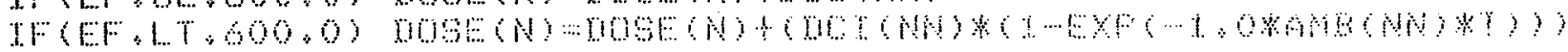

a) GOMTIUUE

WWTE $4 \% 0, T, 006 \%$

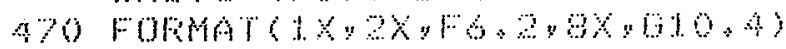

300 GONTTNUE

का

WN! 
DETERMINATION OF DOSE DELIVERED BY SHORT-LIVED RADIONUCLIDES TO REACTOR COOLANT CLEANUP RESIN AT DRESDEN NUCLEAR POWER STATION, UNIT 3

The dose delivered by the beta and gamma emissions of a representative short-lived radionuclide, Ba-140, to the resin in the reactor coolant cleanup bed at Dresden, is calculated below. The calculations are the same for other short-lived isotopes except that the nuclear constants for each specific 1sotope must be used in calculating its delivered dose.

The treatment used here is based on the bulldup on the resin bed of steady-state saturation levels of the isotopes being removed from the coolant stream. These levels are reached.(to within 1\%) in five mean-1ives, and from that time on, their rates of decay are equa 1 to their rates of buildup on the resin, assuming constant coolant flow rate through the bed. Thus, they deliver a continuous dose (and at constant dose rate as long as the reactor power is constant) to the resin all the time the bed is in service. After the bed is removed from service and the RNs decay, the dose from their decay will exactly compensate for the defictt in dose during bulldup, before saturation is reached. Hence, the total dose delivered by the short-lived isotopes is simply the dose rate at saturation multiplied by the time the bed is in service.

The curie amount, $C_{1}$, of an isotope on the resin bed at its steadystate saturation value is given by

$$
C_{1}=A_{1} F e_{r} \tau_{1}
$$

where $A_{1}$ is the activity level of the ith 1sotope in $\mathrm{Cl} / \mathrm{mL}$; F is coolant flow rate through the bed in $\mathrm{mL} / \mathrm{min}$; $e_{r}$ is overall efficiency of activity removal by the bed;

$\tau_{1}$ is the mean-iffe of the ith isotope in minutes.

For the Dresden coolant cleanup system, $e_{r}=0.9$ (using the reported overall decontamination factor of 10 ) and $F$ is $2.27 \times 10^{6} \mathrm{~mL} / \mathrm{min}$. Taking $\mathrm{Ba}-140$ as an example of a specific lsotope removed from the coolant, $C_{1}$ can be obtained using the mean $11 \mathrm{fe}$ of $\mathrm{Ba}-140$ of $2.86 \times 10^{4} \mathrm{~min}$ and its concentration in the coolant of $6.3 \times 10^{-9} \mathrm{Ci} / \mathrm{mL}$.

$$
\mathrm{C}_{\mathrm{Ba}-140}=370 \mathrm{CI}
$$

For $\beta$-decay, $>99 \%$ of the $\beta$-particle energy 18 absorbed by the bed. Thus, the dose rate to the resin, $R_{i}^{\beta}$, in rad/h from $\beta$-decay of the 1 th isotope is obtained from the equation 


$$
\mathrm{R} \beta=\frac{\mathrm{C}_{i} \mathrm{DE}_{i}^{\beta}}{100 \mathrm{~m}_{\mathrm{B}}}
$$

where $C_{1}$ is the number of curies of the 1 th isotope on the bed $\mathrm{D}_{\beta}$ is disintegrations $/ \mathrm{h} / \mathrm{Cl}=1.33 \times 10^{14} \mathrm{~d} / \mathrm{h}$;

$E_{1}^{\beta}$ is the average $\beta$-energy of the 1 th isotope in ergs;

$\mathrm{m}_{\mathrm{B}}$ is the mass in $\mathrm{g}$ of the resin bed, including water. This is $5.0 \mathrm{x}$ $10^{6} \mathrm{~g}$, assuming an overall density of $1 \mathrm{~g} / \mathrm{mL}$.

For $\mathrm{Ba}-140, \mathrm{C}_{1}=370 \mathrm{Cl}$, and $\mathrm{E}_{1}=6.4 \times 10^{-7} \mathrm{erg}$, so that $\mathrm{R}_{\mathrm{Ba}-140}=63 \mathrm{rad} / \mathrm{h}$, and in a six-month operating period (plus time for complete decay of $\mathrm{Ba}-140$ ) the total dose from $\beta$-particles delivered by $\mathrm{Ba}-140$ will be $2.7 \times 10^{5} \mathrm{rad}$.

This result is the same as that obtained using a treatment based on the method of Swyler et al. (9) for calculation of a bsorbed $\beta$-dose due to complete radioactive decay of an isotope. This treatment uses the fact that a specific amount of an isotope trapped by the resin in unit time will deliver, during its decay, an absorbed dose calculated by the method of Swyler et al. The total $\beta$-dose delivered during the operating perlod of the resin bed will then be just this amount multiplied by the total time the bed is kept in service.

For $\beta$-dose determination, which is straightforward with respect to energy a bsorption (essentially all the $\beta$-particle energy is absorbed in the resin bed), either treatment may be used. The same is true for determination of $\gamma$-dose, but the latter requires estimation of the extent of $\gamma$-ray absorption in the resin bed. Since absorption coefficients and geometry factor are a 1ready included in the calculation of Swyler et al., it is convenient to use that method for determination of the $\gamma$-dose, keeping in mind that the calculation gives the maximum dose, due to assumption of uniform loading.

Using the notation of Swyler et al, the total $\gamma$-dose delivered by an isotope in six months, $D_{1}($ tota 1$)$, is given by

$$
D_{1}^{\gamma}(\operatorname{tota} 1)=D_{1}^{\gamma}(\infty) \times 2.63 \times 10^{5} \text { minutes in six months }
$$

and $D_{i}^{\gamma}(\infty)=\frac{C_{i} \Gamma_{i} \bar{g} \times 8.76 \times 10^{3} \mathrm{~h} \cdot \mathrm{yr}^{-1}}{\lambda_{i}}$

where $C_{1}$ is the activity density of the 1 th isotope in $\mathrm{mCl} / \mathrm{cm}^{3}$;

$\Gamma_{1}$ is the gamma constant for the ith 1sotope; 
$\overline{\mathrm{g}}$ is a geometric factor

$\lambda_{1}$ is the decay constant of the 1 th isotope in $\mathrm{yr}^{-1}$.

For the dimensions of Dresden's coolant cleanup bed $\bar{g}=270 \mathrm{~cm}$. For $\mathrm{Ba}-140, \mathrm{C}_{1}=2.6 \times 10^{-6} \mathrm{mC1} / \mathrm{cm}^{3}, \Gamma_{1}=12.4$ and $\gamma_{i}=19.8 \mathrm{yr}^{-1}$.

Thus, the $\gamma$-dose delivered by $\mathrm{Ba}-140$ in $\mathrm{six}$ months is calculated to be $10.1 \mathrm{x}$ $10^{5} \mathrm{rad}$, and the total dose, both $\beta$ and $\gamma$ is $12.8 \times 10^{5} \mathrm{rad}$, or $\sim 1.3 \mathrm{x}$ $10^{6} \mathrm{rad}$. 


\begin{tabular}{|c|c|c|c|}
\hline \multicolumn{2}{|l|}{ 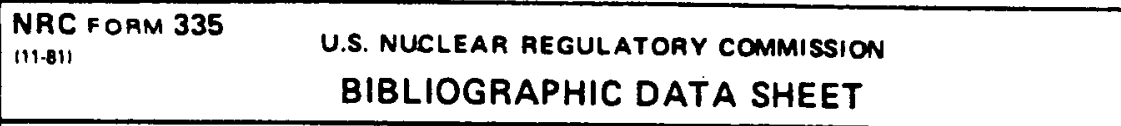 } & \multicolumn{2}{|c|}{$\begin{array}{l}\text { 1. REPORT NUMBE R (Assigned or DOC) } \\
\text { NUREG/CR-2830 } \\
\text { BNL-NUREG-51565 }\end{array}$} \\
\hline \multirow{2}{*}{\multicolumn{2}{|c|}{$\begin{array}{l}\text { 4. TITLE AND SUBTITLE (AddVolume No., it sopropriate) } \\
\text { Permissible Radionucl ide Loading for } \\
\text { Organic Ion Exchange Resins from } \\
\text { Nuclear Power Plants }\end{array}$}} & \multicolumn{2}{|l|}{ 2. (Leave blank) } \\
\hline & & \multicolumn{2}{|c|}{ 3. RECIPIENT S ACCESSION NO. } \\
\hline \multicolumn{2}{|l|}{ 7. AUTHOR(S) D. R. Mackenzie, M. Lin, R.E. Barletta } & \multicolumn{2}{|c|}{\begin{tabular}{|l|l|}
$\begin{array}{l}\text { 5. DATE REPORT COMPLETED } \\
\text { MONTH } \\
\text { June }\end{array}$ & 1982 \\
\end{tabular}} \\
\hline \multirow{3}{*}{\multicolumn{2}{|c|}{$\begin{array}{l}\text { 9. PERFORMING ORGANIZATION NAME AND MAILING ADDRESS (Include Zip Code) } \\
\text { Brookhaven National Laboratory } \\
\text { Upton, New York } 11973\end{array}$}} & \multirow{2}{*}{\multicolumn{2}{|c|}{$\begin{array}{l}\text { DATE REPORT ISSUED } \\
\begin{array}{l|l}\text { MONTH } \\
\text { October }\end{array}{ }^{\text {TEEAR }} 1983\end{array}$}} \\
\hline & & & \\
\hline & & \multicolumn{2}{|l|}{ 6. (Leave blank) } \\
\hline & & \multicolumn{2}{|l|}{ 8. (Leave b/ank) } \\
\hline \multirow{2}{*}{\multicolumn{2}{|c|}{$\begin{array}{l}\text { 12. SPONSORING ORGANIZATION NAME AND MAILING ADDRESS (Include Zio Code) } \\
\text { Division of Waste Management } \\
\text { Office of Nuclear Material Safety and Safeguards } \\
\text { U.S. Nuclear Regulatory Commission } \\
\text { Washington, D.C. } 20555\end{array}$}} & \multicolumn{2}{|c|}{ 10. PROJECT/TASK/WORK UNIT NO. } \\
\hline & & \multicolumn{2}{|l|}{ 11. FIN NO. } \\
\hline \multicolumn{4}{|l|}{$\begin{array}{l}\text { 13. TYPE OF REPORT } \\
\text { Technical Report }\end{array}$} \\
\hline \multicolumn{2}{|l|}{ 15. SUPPLEMENTARY NOTES } & \multicolumn{2}{|l|}{ 14. (Leave olank) } \\
\hline \multicolumn{4}{|c|}{$\begin{array}{l}\text { 16. ABSTRACT } 200 \text { words or lessi A questionnaire on the use of ion exchange resins in nuclear power } \\
\text { plants was sent to all operating reactors in the } U \text {.S. Responses were received from } 23 \text { of } \\
\text { the } 48 \text { utilities approached. Information was sought concerning the amounts of radionuclide } \\
\text { held by the resins, and the effects of its radiation on the resins both during operation } \\
\text { and a fter removal from service. Relevant information from the questionnaires is summarized } \\
\text { and discussed. Available literature on the effects of ionizing radiation on organic ion } \\
\text { exchange resins has been reviewed. On the basis of published data on damage to resins by } \\
\text { radiation, the technical rationale is given to support NRC's draft branch technical position } \\
\text { on a maximum permissible radionuclide loading. It is considered advisable to formulate the } \\
\text { rule in terms of a delivered dose rather than a curie loading. A maximum permissible dose } \\
\text { of } 108 \text { rad is chosen because, while it is large enough that a measurable amount of damage } \\
\text { will be done to the resin, it is small enough that the damage will be negligible at a } \\
\text { power plant or disposal site. A test procedure has been written which a generator could } \\
\text { use to qualify a specific resin for service at a higher dose than permitted by the general } \\
\text { rule. }\end{array}$} \\
\hline \multicolumn{4}{|l|}{ 17. KEY WORDS AND DOCUMENT ANALYSIS } \\
\hline \multicolumn{4}{|l|}{$\begin{array}{l}\text { 1) Permissible Radionuclide Loading } \\
\text { 2) Damage to resins by radiation } \\
\text { 3) Low-Level Waste resin Disposal Requirements }\end{array}$} \\
\hline \multicolumn{4}{|l|}{ 17b. IDENTIFIERS: OPEN-ENDED TERMS } \\
\hline \multirow{2}{*}{$\begin{array}{l}\text { 18. AVAILABILITY STATE } \\
\text { Unlimited }\end{array}$} & 19. SE & $\begin{array}{l}\text { CLASS IThis report } \\
\text { sified }\end{array}$ & 21. NO. OF PAGES \\
\hline & 20. SE & $\begin{array}{l}\text { Chass (This page) } \\
\text { sified }\end{array}$ & \begin{tabular}{|l} 
22. PRICE \\
$\mathrm{S}$
\end{tabular} \\
\hline
\end{tabular}

